\title{
Hydrogeochemistry and Simulated Solute Transport, Piceance Basin, Northwestern Colorado
}

GEOLOGICAL SURVEY PROFESSIONALAPAER 1196

Prepared in cooperation with the U.S. Environmental Protection Agency

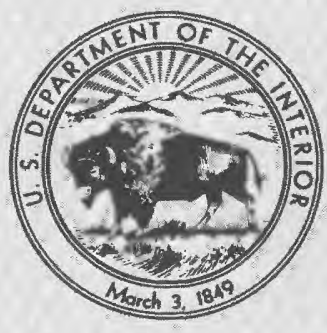




\section{Hydrogeochemistry and Simulated Solute Transport, Piceance Basin, Northwestern Colorado}

By STANLEY G. ROBSON and GEORGE J. SAULNIER, JR.

GEOLOGICAL SURVEY PROFESIONAL PAPER 1196

Prepared in cooperation with the U.S. Environmental Protection Agency

The hydrogeochemistry of the oil-shale-rich area is described and a digital model is used to simulate the possible effects of proposed oil-shale mining on ground-water quality

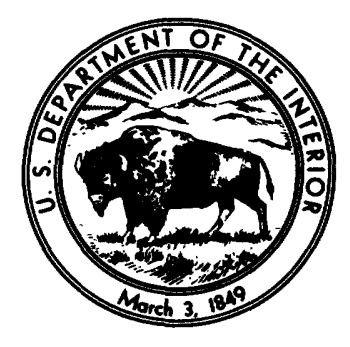




\title{
UNITED STATES DEPARTMENT OF THE INTERIOR
}

\author{
JAMES G. WATT, Secretary
}

GEOLOGICAL SURVEY

Doyle G. Frederick, Acting Director

Library of Congress Cataloging in Publication Data

Robson, Stanley G.

Hydrogeochemistry and simulated solute transport, Piceance basin, northwestern Colorado.

(Geological Survey Professional Paper 1196)

Prepared in cooperation with the U.S. Environmental Protection Agency.

Bibliography: p. 63

Supt. of Docs. no.: I 19.16

1. Oil-shale industry-Environmental aspects-Colorado-Piceance Creek watershed. 2. Hydrology-ColoradoPiceance Creek watershed. 3. Geochemistry-Colorado-Piceance Creek watershed. I. Saulnier, George J., joint author. II. United States Environmental Protection Agency. III. Series: United States Geological Survey Professional Paper 1196

TD1 95.04R62

$628.1 ' 6836$

80-607137

For sale by the Superintendent of Documents, U.S. Government Printing Office

Washington, D.C. 20402 


\section{GONTENTS}

Conversion factors

Abstract

Introduction

The natural hydrologic system

Aquifer characteristics

Fracturing

Aquifer limits

Elevation and thickness of bedding in aquifers

Hydraulic conductivity

Porosity and compressibility

Ground-water recharge, discharge, and potentiometric

heads

Ground-water recharge and discharge

Potentiometric surfaces ..................................................... 20

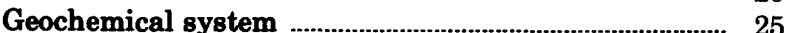

Chemical reactions .................................................................. 26

Dissolution ......u.u.

Precipitation ..................................................................... 29

Ion exchange …….................................................... 29

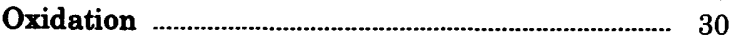

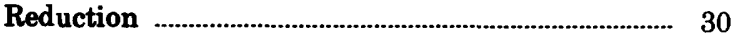

Stratigraphy

\begin{tabular}{|c|c|c|}
\hline age & & Pag \\
\hline V & Distribution of trace constituents & 3 \\
\hline 1 & Arsenic & 3 \\
\hline 1 & (2) & 3 \\
\hline 3 & Boron .. & 3 \\
\hline 3 & (1) & 3 \\
\hline 7 & 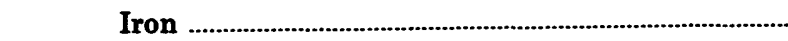 & 3 \\
\hline 7 & 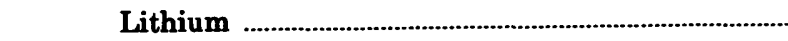 & 3 \\
\hline 7 & 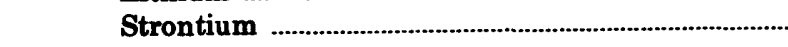 & 3 \\
\hline 7 & The simulated hydrologic system & \\
\hline 10 & Model description & 3 \\
\hline 13 & Model calibration & 3 \\
\hline 15 & Hydrologic knowledge gained through modeling ........ & \\
\hline 18 & Model simulations & \\
\hline 20 & (1) & 4 \\
\hline 25 & 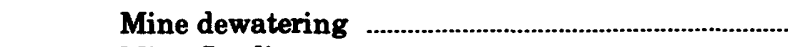 & \\
\hline 26 & 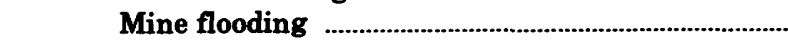 & \\
\hline 27 & (n) & \\
\hline 29 & 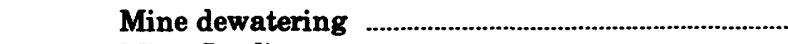 & 5 \\
\hline 29 & 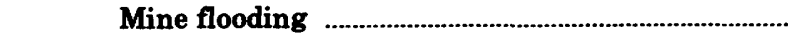 & \\
\hline 30 & 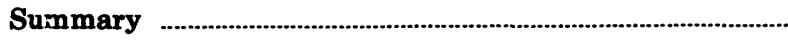 & 6 \\
\hline 30 & (1) & \\
\hline
\end{tabular}

\section{ILLUSTRATIONS}

FIGURE 1. Map showing location of study area

2. Generalized geologic sections through the Piceance basin

3-22. Maps showing:

3. Extent of surficial fracturing

4. Structure contours on the base of the Uinta Formation

5. Saturated thickness of the Uinta Formation

6. Structure contours on the top of the Mahogany zone

Saturated thickness of the Parachute Creek Member above the Mahogany zone

8. Saturated thickness of the Mahogany zone

9. Saturated thickness of the interval from the base of the Mahogany zone to the base of the R- 6 zone

10. Structure contours on the base of the lower aquifer

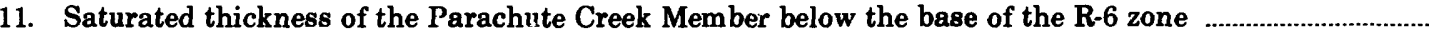

12. Lateral and vertical hydraulic conductivity for layer 1 .

13. Lateral and vertical hydraulic conductivity for layer 2

14. Lateral hydraulic conductivity for layer 3

15. Vertical hydraulic conductivity for layer 3

16. Lateral hydraulic conductivity for layers 4 and 5

17. Vertical hydraulic conductivity for layers 4 and 5

18. Potentiometric surface of the upper aquifer

19. Potentiometric surface of the lower aquifer

20. Difference in potentiometric heads between the upper and lower aquifers

21. Estimated dissolved-solids concentrations in water recharging the aquifer system

22. Major faults and joints in the northern part of the Piceance basin

23. Graph showing distribution of differences between calculated and measured values of potentiometric head for layers 1 and 5 . 
FIgURE 24-30. Maps showing:

24. Measured and calculated dissolved-solids concentrations for layer 1

25. Measured and calculated dissolved-solids concentrations for layer 2

26. Measured and calculated dissolved-solids concentrations for layer 3

27. Measured and calculated dissolved-solids concentrations for layer 4

28. Measured and calculated dissolved-solids concentrations for layer 5

29. Precipitation recharge distribution

30. Rate of dissolution of saline minerals at the base of the aquifer system

31. Graph showing cumulative ground-water discharge distribution and dissolved-solids concentrations along Piceance and Yellow Creeks

32-34. Maps showing:

32. Model-calculated drawdown in layer 5 produced by pumping mine near tract $\mathrm{C}-\mathrm{a}$ at 5 cubic feet per second

33. Model-calculated decrease in dissolved-solids concentrations in layer 2 produced by pumping mine near tract $\mathbf{C}-\mathbf{a}$ at 5 cubic feet per second

35-37. Graphs showing:

34. Model-calculated change in dissolved-solids concentrations in layer 5 produced by pumping mine near tract $\mathrm{C}-\mathrm{a}$ at $\mathbf{5}$ cubic feet per second

35. Change in model-calculated ground-water discharge and dissolved-solids concentrations in Yellow Creek valley produced by pumping mine near tract $\mathrm{C}-\mathrm{a}$ at 5 cubic feet per second

36. Change in dissolved-solids concentrations in aquifers adjacent to abandoned mine near track $\mathrm{C}-\mathrm{a}$ after 60 years of leaching

37. Change in dissolved-solids concentrations with time in aquifers adjacent to abandoned mine for leaching rate of $1.3 \times 10^{5}$ pounds per day

38-40. Maps showing:

38. Model-calculated increase in dissolved-solids concentrations in layer 2 after 60 years of leaching from abandoned mine at $1.3 \times 10^{5}$ pounds per day

39. Model-calculated drawdown in layer 5 produced by pumping mine in tract $\mathrm{C}-\mathrm{b}$ at $\mathbf{1 5}$ cubic feet per second

40. Model-calculated change in dissolved-solids concentrations in layer 5 produced by pumping mine in tract $\mathrm{C}-\mathrm{b}$ at 15 cubic feet per second

41-43. Graphs showing:

41. Change in model-calculated ground-water discharge and dissolved-solids concentrations in Piceance Creek valley produced by pumping mine in tract $\mathrm{C}-\mathrm{b}$ at 15 cubic feet per second

42. Change in dissolved-solids concentrations in aquifers adjacent to abandoned mine in tract $\mathrm{C}-\mathrm{b}$ after 60 years of leaching

43. Change in dissolved-solids concentrations with time in aquifers adjacent to abandoned mine in tract $\mathrm{C}-\mathrm{b}$ for leaching rate of $1.3 \times 10^{5}$ pounds per day

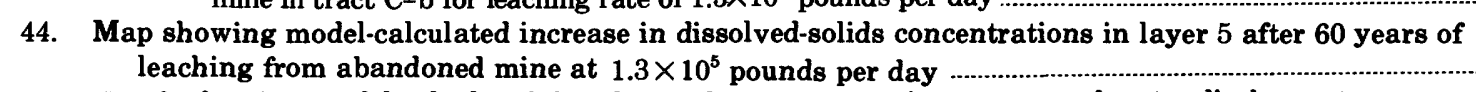

44. Map showing model-calculated increase in dissolved-solids concentrations in layer 5 after 60 years of
leaching from abandoned mine at $1.3 \times 10^{5}$ pounds per day

45. Graph showing model-calculated dissolved-solids concentrations in ground-water discharge to

Piceance Creek valley produced after 60 years of leaching from abandoned mine

in tract $\mathrm{C}-\mathrm{b}$ at $1.3 \times 10^{5}$ pounds per day

\section{TABLES}

TABLE 1. Stratigraphic units in Piceance basin

2. Ground-water mass balance

3. Mineral-dissolution rates

4. Distribution of total pumpage by model layer for tract $\mathrm{C}-\mathrm{b}$ 


\section{CONVERSION FACTORS}

For the reader who may prefer to use metric units rather than inch-pound units, the conversion factors for the terms used in this report are listed below:

Multiply inch-pound unit

acre

acre-foot (acre-ft)

barrel

foot (ft)

foot per day (ft/d)

foot per mile ( $\mathrm{ft} / \mathrm{mi})$

cubic foot per second $\left(\mathrm{ft}^{3} / \mathrm{s}\right)$

foot per year ( $\mathrm{ft} / \mathrm{yr})$

gallon per ton (gal/ton)

square inch per pound $\left(\mathrm{in}^{2} / \mathrm{lb}\right)$

mile (mi)

square mile $\left(\mathrm{mi}^{2}\right)$

pound per day (lb/d)

pound per day per square mile

$\left[(\mathrm{lb} / \mathrm{d}) / \mathbf{m i}^{2}\right]$

pound per square inch $\left(l b / \mathrm{in}^{2}\right)$

ton, short
By

To obtain metric unit

$4.047 \times 10^{-1}$

$1.234 \times 10^{-3}$

$1.59 \times 10^{1}$

$3.048 \times 10^{-1}$

$3.048 \times 10^{-1}$

$1.894 \times 10^{-1}$

$2.832 \times 10^{-2}$

$3.048 \times 10^{-1}$

$4.171 \times 10^{-2}$

$1.450 \times 10^{-1}$

1.609

2.590

$4.536 \times 10^{-1}$

$1.751 \times 10^{-1}$

6.895

$9.072 \times 10^{-1}$ hectare

cubic hectometer

cubic meter

meter

meter per day

meter per kilometer

cubic meter per second

meter per year

cubic meter per megagram

kilopascat-1

kilometer

square kilometer

kilogram per day

kilogram per day per

square kilometer

kilopascal

metric ton 



\title{
HYDROGEOCHEMISTRY AND SIMULATED SOLUTE TRANSPORT, PICEANCE BASIN, NORTHWESTERN COLORADO
}

\author{
By Stanley G. Robson and George J. Saulnier, JR.
}

ABSTRACT

The Piceance basin of northwestern Colorado contains rich deposits of oil shale in sedimentary rocks of the Parachute Creek Member of the Green River Formation. Plans for mining these deposits in Federal prototype lease tracts $\mathrm{C}-\mathrm{a}$ and $\mathrm{C}-\mathrm{b}$ require ground water to be pumped to allow the construction of underground retorts for use in extracting the shale oil. The possible adverse effects of mine pumping and resaturation of spent shale in an abandoned mine were investigated by studying the geochemistry of the aquifers and by use of ground-water quality modeling techniques.

The aquifers in the basin crop out along the east, north, and west margins of the basin and attain a saturated thickness of 2,000 feet in the northeast part of the basin. Faults, joints, collapse breccia, and solution cavities are the primary source of permeability in the otherwise impermeable sandstone and marlstone sedimentary rocks. Estimates of the lateral hydraulic conductivity of the aquifers range from 0.1 to 2.0 feet per day and of the vertical hydraulic conductivity from $7 \times 10^{-4}$ to 1.0 foot per day, respectively.

Ground-water recharge occurs from infiltration of precipitation in the upland areas along the east, south, and west margins of the basin. From the recharge areas, ground water moves vertically into deeper zones in the aquifers and laterally toward the discharge areas along Piceance and Yellow Creeks and their tributaries. The steady-state recharge discharge rate of 32 cubic feet per second results in hydraulic gradients in the aquifers of as much as 130 feet per mile in some parts of the basin.

The saline zone, located at the base of the Parachute Creek Member, contains the soluble minerals naholite and halite and is the primary source of the dissolved solids in the ground water. Dissolution of minerals in the unsaturated zone and in the aquifers also contribute dissolved solids to the water. Additional chemical reactions occurring in the aquifers include precipitation, ionexchange, and oxidation-reduction reactions. The product of the principal chemical reactions is a sodium bicarbonate water with oxidized sulfur species in the Uinta Formation and reduced sulfur species in the Parachute Creek Member. Carbonate species are produced primarily by reduction of sulfur species and dissolution of the carbonate minerals calcite, dolomite, and nahcolite. Carbonate species are removed from the system in the northern part of the basin by calcite precipitation. Relatively large sodium concentrations are produced by ion exchange and nahcolite and halite dissolution. Local brines are produced where faults exposed saline minerals to circulating ground water.

A mathematical model was used to simulate the ground-water quality changes that would occur as a result of mine dewatering or leaching of saline minerals from an abandoned mine. The model simulates confined density-dependent flow and solute transport in three dimensions with dispersion in nonhomogeneous, anisotropic aquifers under steady or transient ground-water flow conditions. An acceptable model calibration was achieved for steady-state flow conditions.

Simulations of pumping mines in tracts $\mathrm{C}-\mathrm{a}$ and $\mathrm{C}-\mathrm{b}$ indicate that the altered direction of ground-water movement near the pumped mines will decrease dissolved-solids concentrations in ground water near the mines and increase dissolved-solids concentrations in some areas downgradient from the mines. Simulated long-term pumping from tract $\mathrm{C}-\mathrm{a}$ at a rate of 5 cubic feet per second indicates that ground-water discharge to Yellow Creek will be reduced by as much as 2 cubic feet rer second and to Piceance Creek by as much as 3 cubic feet per second. Simulated long-term pumping from tract $\mathrm{C}-\mathrm{b}$ at 15 cubic feet per second indicates that ground-water discharge to Piceance Creek will be reduced by as much as 15 cubic feet per second and dissolved-solids concentration in the creek will be increased by as much as 300 milligrams per liter.

Leaching of saline minerals contained in spent shale in an abandoned and flooded mine could have an adverse affect on the surface-and ground-water quality in the basin. Model simulations of mine leaching in tract $\mathrm{C}-\mathrm{a}$ indicate that the dissolved-solids concentration of ground water in a 140-8quare-mile area downgradient from the tract would be increased by more than 10 milligrams per liter after 60 years of leaching. Dissolved-solids concentrations as much as 40,000 milligrams per liter were produced adjacent to the simulated mine. After 60 years of leaching, the water quality in Yellow Creek had not yet been adversely affected by the degraded quality of the ground water. Simulations of mine leaching at tract $\mathrm{C}-\mathrm{b}$ indicate that the dissolved-solids concentration in a 40-8quare-mile area near the tract would be increased by more than 10 milligrams per liter after 60 years of leaching. The estimated dissolved-8olids concentration in Piceance Creek increased from 750 to 1,750 milligrams per liter in a reach of the creek near tract $C-b$. Modeling thus indicates that equal rates of mine leaching from tracts $\mathrm{C}-\mathrm{a}$ and $\mathrm{C}-\mathrm{b}$ will produce much different effects on the water quality in the Piceance basin. Tract $\mathrm{C}-\mathrm{a}$, by virtue of its remote location from perennial streams, will primarily degrade the ground-water quality over a large area to the northeast of the tract. Tract $C-b$, by contrast, will primarily degrade the surface-water quality in Piceance Creek with only localized effects on the ground-water quality.

\section{INTRODUCTION}

The Piceance basin of northwestern Colorado (fig. 1) contains rich deposits of kerogen-bearing dolomitic marlstone (oil shale) and saline minerals in lacustrine sediments of the Eocene Green River For- 


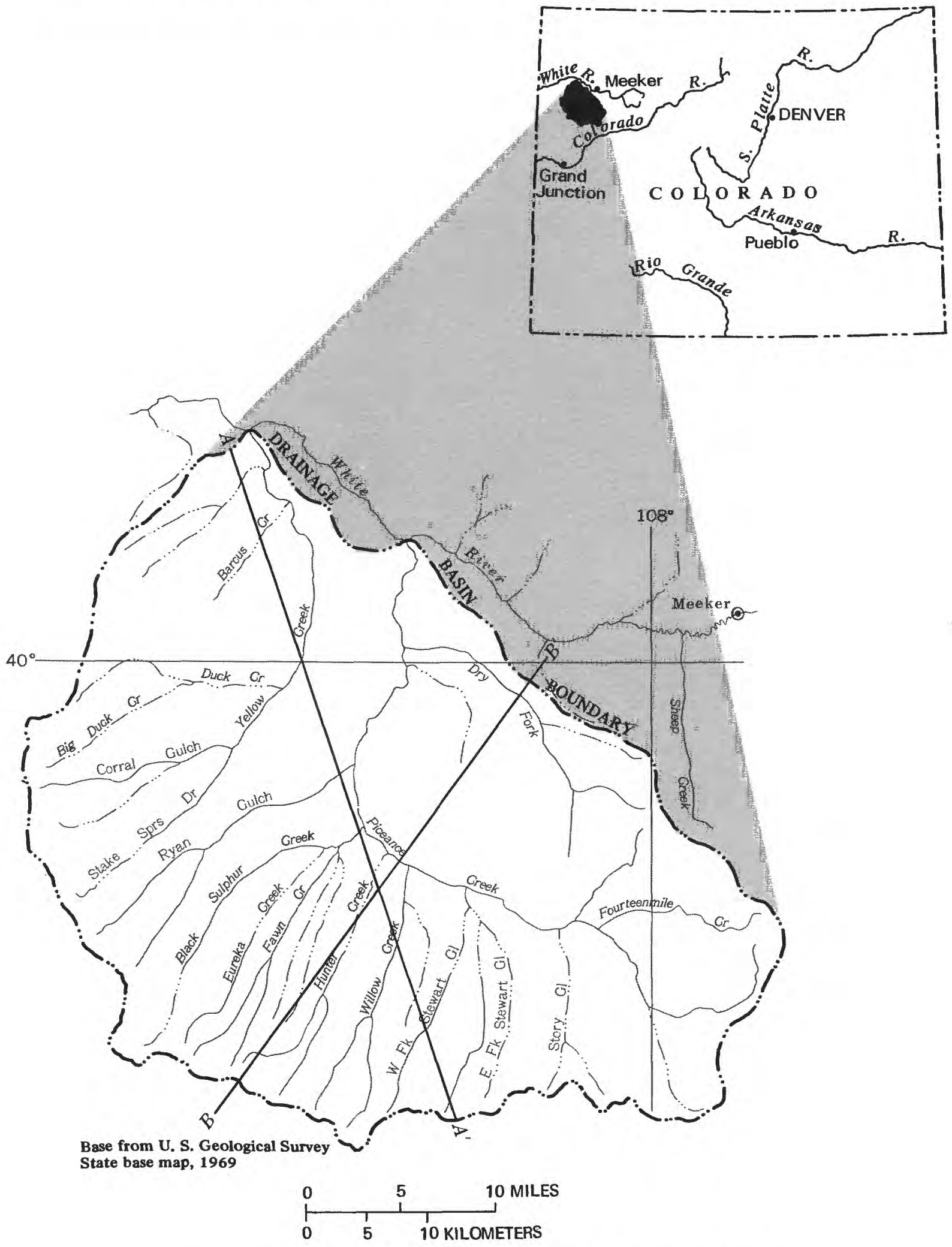

Figure 1.-Location of study area (sections $A \cdot A^{\prime}$ and $B \cdot B^{\prime}$ shown in figure 2). 
mation. The estimated total reserves of the Piceance structural basin amount to $1.2 \times 10^{12}$ barrels of shale oil (Culbertson and Pitman, 1973)-more than the total oil consumption of the United States to date (1979). The magnitude of these oil-shale deposits has resulted in intense exploration by energy companies and the leasing by the Federal government of two 5,000-acre prototype mining tracts, $\mathrm{C}-\mathrm{a}$ and $\mathrm{C}-\mathrm{b}$. Present mining plans for tracts $\mathrm{C}-\mathrm{a}$ and $\mathrm{C}-\mathrm{b}$ include the use of a modified in-situ recovery process that will require dewatering of the mining zone as a prerequisite to shale-oil extraction. Mine dewatering and related mining activities could have a significant effect on the quantity and chemical quality of the ground and surface water in the basin. Leachate produced by ground-water dissolution of saline minerals in spent shale in an abandoned and flooded mine also could degrade the ground- and surfacewater quality on and near the tracts.

The purpose of this study was to investigate the hydrogeochemistry of the aquifers in the Piceance basin and to evaluate the potential effects of mining activities on the chemical quality of the water resources of the basin.

To meet this objective, the extent, depth, thickness, and hydrologic characteristics of the aquifers in the Piceance basin were estimated. In addition, areal variations in dissolved-solids concentrations and the occurrence and distribution of major ions and trace constituents were described. Mineral reactions, such as dissolution of the saline minerals nahcolite $\left(\mathrm{NaCO}_{3}\right)$ and halite $(\mathrm{NaCl})$, and precipitation of other minerals were studied, as were variations in oxidation and reduction conditions and ion-exchange reactions in the aquifers. Some of these data were used to develop and calibrate a three-dimensional mathematical model that is capable of simulating the spatial and temporal changes in potentiometric heads and dissolved-solids concentrations in five layers representing different depth intervals in the aquifers. By modeling ground-water movement and quality, it is possible to estimate the changes in the ground- and surface-water quality in the basin that may result from mine dewatering or leaching of spent shale in an abandoned and flooded mine.

Primary funding for this work was provided by the U.S. Geological Survey through energy research and development funds, and Federal program funds. Additional support was provided by the U.S. Environmental Protection Agency through energy research and development funds.

\section{THE NATURAL HYDROLOGIC SYSTEM}

\section{STRATIGRAPHY}

The stratigraphy of the Piceance basin has been described previously by Donnell (1961), Coffin, Welder, and Glanzman (1971), Dyni (1974), and Cashion and Donnell (1974). Descriptions of the various stratigraphic units are given in table 1 . Generalized geologic sections showing the vertical relationships of these units are shown in figure 2.

The Green River Formation conformably overlies the Wasatch Formation in Piceance basin. The Green River Formation is composed of a basal sandstone unit (Douglas Creek Member) containing some limestone and shale that is overlain by a finely laminated shale and barren marlstone (Garden Gulch Member) containing some sandstone and limestone.The Garden Gulch Member is overlain by a large amount of kerogen-rich dolomitic marlstone (Parachute Creek Member). The Douglas Creek and Garden Gulch Members undergo a facies change near the northern and eastern edge of the basin where the units occur as heterogeneous layers of shale, sandstone, and barren marlstone and are mapped as the Anvil Points Member by Donnell (1961). The Anvil Points, Garden Gulch, and Douglas Creek Members yield little or no water to wells and, in this study, are considered to be an impermeable base to the overlying aquifer system.

The Parachute Creek Member of the Green River Formation contains economically valuable oil shale, large volumes of ground water, and soluble saline minerals. The most common saline mineral in the Parachute Creek Member is nahcolite, with halite occurring in lesser concentrations. Nahcolite predominately occurs as large crystal rosettes and nodules as much as $3 \mathrm{ft}$ in diameter (Dyni, 1974). Nahcolite also occurs in relatively thin beds of almost pure nahcolite and as disseminated crystals in zones of varying thickness. The sediments containing the majority of the saline minerals are located near the center of the basin at the base of the Parachute Creek Member. This saline zone is relatively impermeable except in areas where fractures have allowed ground water access to the soluble minerals. A stratigraphic horizon containing numerous vugs, cavities, and collapse breccia occurs in areas where nahcolite has been dissolved from the formation. This horizon, referred to as the leached zone (Hite and Dyni, 1967), extends from either the base of the Parachute Creek Member or the top of the saline zone to, and in some 


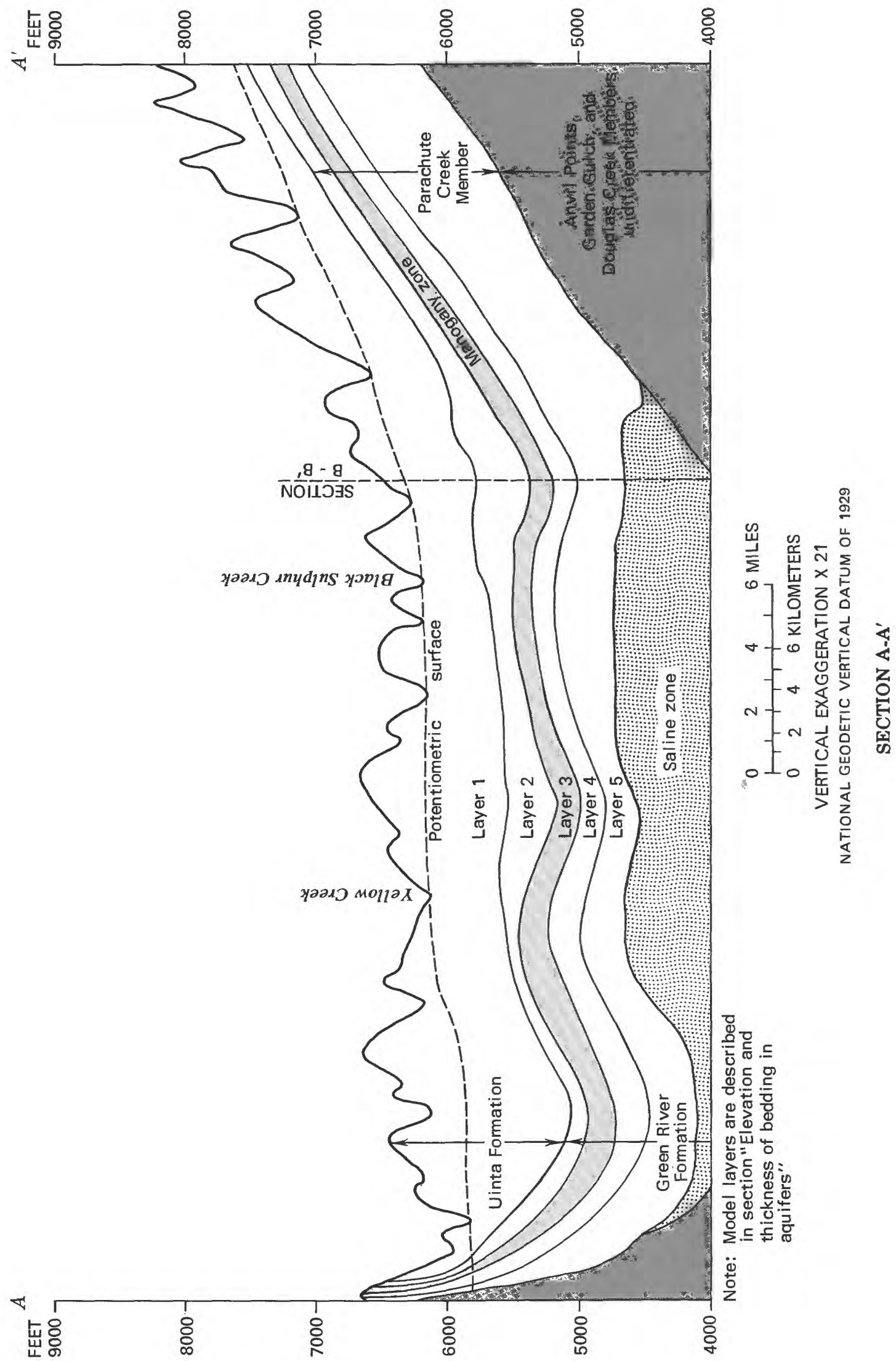




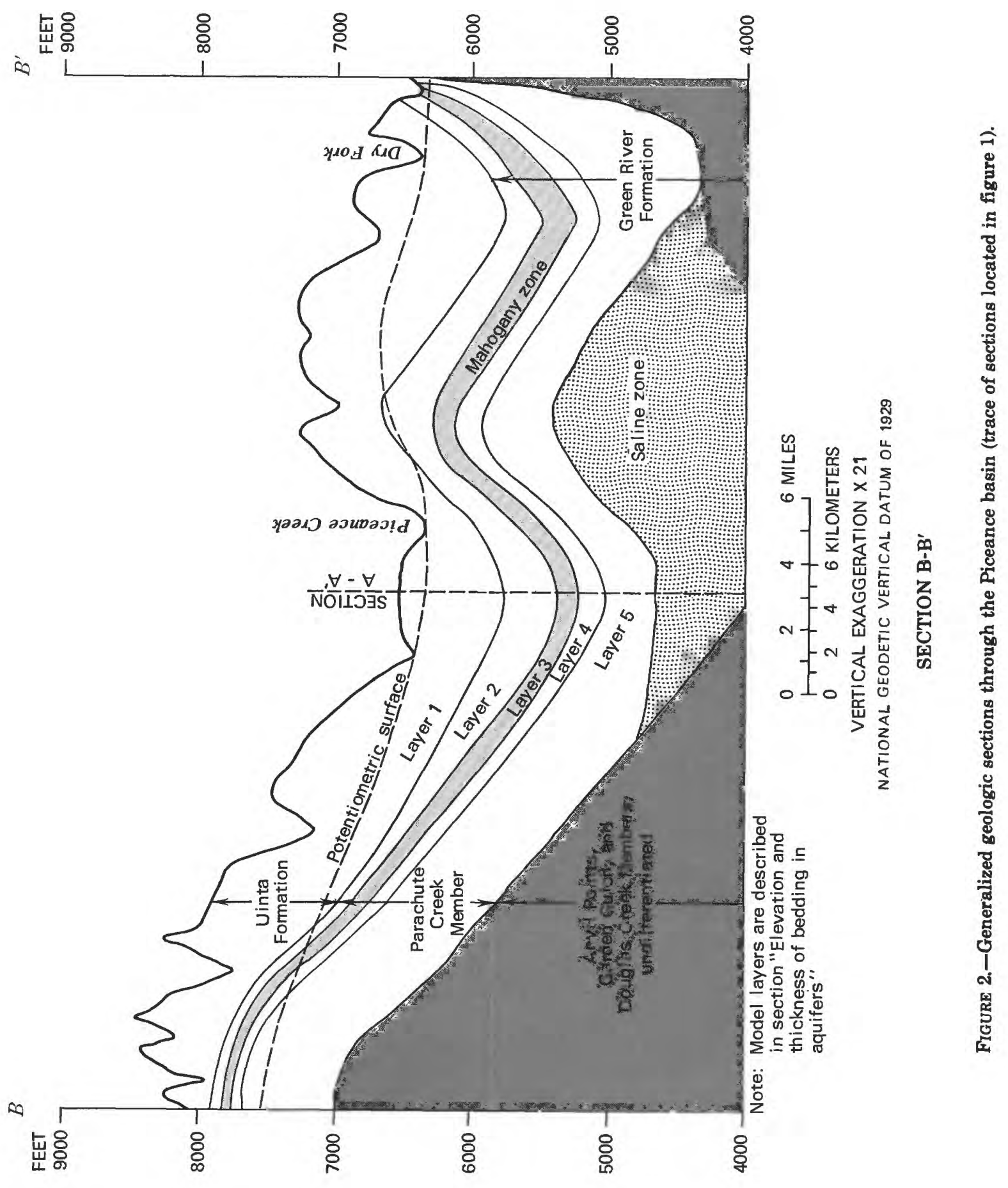


TABLE 1. - Stratigraphic units in Piceance basin

[Modified from Coffin, Welder, and Glanzman, 1971]

\begin{tabular}{|c|c|c|c|}
\hline Geologic age & & $\begin{array}{l}\text { Geologic unit } \\
\text { and thickness }\end{array}$ & Lithologic and hydraulic characteristics \\
\hline $\begin{array}{l}\text { Holocene and } \\
\text { Pleistocene }\end{array}$ & & $\begin{array}{c}\text { Alluvium, } \\
0-140 \mathrm{ft}\end{array}$ & Heterogeneous clay, sand, and gravel. \\
\hline \multirow{5}{*}{ Eocene } & & $\begin{array}{l}\text { Uinta } \\
\text { Formation, } \\
0-1,400 \mathrm{ft}\end{array}$ & $\begin{array}{l}\text { Coarse- to fine-grained, poorly sorted, silty sandstone, siltstone with some barren marlstone. } \\
\text { Little or no primary porosity remains due to calcium carbonate and silica cementation. Some } \\
\text { secondary porosity due to fractures. Hydraulic conductivity is relatively small. }\end{array}$ \\
\hline & \multirow{4}{*}{ 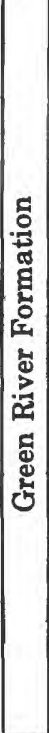 } & $\begin{array}{c}\text { Parachute } \\
\text { Creek } \\
\text { Member, } \\
500- \\
1,400 \mathrm{ft}\end{array}$ & $\begin{array}{l}\text { Kerogenaceous dolomitic marlstone with some thin ash beds. The unit is lacustrine, with a } \\
\text { varved appearance and can be divided into four parts. The lower, relatively impermeable } \\
\text { part of the unit contains saline minerals and is referred to as the saline zone. The leached } \\
\text { zone overlies the saline zone and has a relatively large hydraulic conductivity due to voids } \\
\text { produced by dissolution and fractures. The Mahogany zone, the richest oil-shale interval in } \\
\text { the section, overlies the leached zone and has a relatively small hydraulic conductivity } \\
\text { throughout most of the basin. The Mahogany zone is overlain by the upper part of the mem- } \\
\text { ber, which is fractured and water-bearing. }\end{array}$ \\
\hline & & $\begin{array}{l}\text { Anvil Points } \\
\text { Member, } \\
0-1,800 \mathrm{ft}\end{array}$ & $\begin{array}{l}\text { Shale, sandstone, and barren marlstone with minor amounts of siltstone and algal and oolitic } \\
\text { marlstone. A basin-edge facies which grades into the Garden Gulch and Douglas Creek } \\
\text { Members. Relatively impermeable. }\end{array}$ \\
\hline & & $\begin{array}{l}\text { Garden Gulch } \\
\text { Member, } \\
0-900 \mathrm{ft}\end{array}$ & $\begin{array}{l}\text { Shale and barren marlstone with local thin beds of sandstone and limestone. A basin-edge } \\
\text { facies best developed in the southern part of the basin. Relatively impermeable. }\end{array}$ \\
\hline & & \begin{tabular}{|c|} 
Douglas Creek \\
Member, \\
$0-800 \mathrm{ft}$
\end{tabular} & Sandstone with some limestone and shale. Relatively impermeable. \\
\hline
\end{tabular}

places into, the lower part of the Mahogany zone. Alternating layers of marlstone containing more than $30 \mathrm{gal} /$ ton on shale oil (rich) and less than 15 gal/ton (lean) have been identified and sequentially numbered by Donnell and Blair (1970) and Cashion and Donnell (1972). These alternating rich and lean layers occur in the leached and saline zones and are used as stratigraphic markers throughout much of the basin.

The Mohogany zone is the most consistently rich and areally extensive interval of oil shale in the Piceance basin, being correlated in outcrops and electric logs throughout the basin. The Mahogany zone is located in the upper one-third of the Parachute Creek Member and is considered the principal mining zone in lease tracts $\mathrm{C}-\mathrm{a}$ and $\mathrm{C}-\mathrm{b}$. The Mahogany zone appears to have fewer fractures than the overlying and underlying units. As a consequence, the hydraulic conductivity of the zone is generally smaller than in the adjacent units. Because of this, Coffin, Welder, and Glanzman (1971) and Weeks, Leavesley, Welder, and Saulnier (1974), considered the ground-water system in the basin to be a two- aquifer system with the Mahogany zone being a leaky confining layer between the upper and lower aquifers. The part of the Parachute Creek Member above the Mahogany zone consists of alternating rich and lean layers of oil shale that are overlain by the Uinta Formation.

The Uinta Formation consists of discontinuous layers of silty sandstone, siltstone, and barren marlstone, and is exposed at the surface throughout much of the Piceance basin. The Uinta Formation is about $1,400 \mathrm{ft}$ thick near the northern end of the study area (fig. 2) but the thickness varies considerably due to the steep, dissected topography in the basin. The Uinta Formation is hydrologically connected to the upper part of the Parachute Creek Member but is less permeable except where fractures locally enhance water movement (Saulnier and Ford, 1977).

Alluvial sediments that occur in the major stream valleys in the basin are derived locally from the Green River and Uinta Formations. The width of the alluvium generally is less than $0.5 \mathrm{mi}$ and the thickness ranges from 0 to about $140 \mathrm{ft}$. Where saturated, the alluvium can serve as a source of recharge to the 
bedrock aquifers or a sink for discharge from the bedrock aquifers depending on local differences in potentiometric heads between the alluvial aquifers and the bedrock aquifers.

\section{AQUIFER CHARACTERISTICS}

The basic aquifer terminology for the Piceance basin was proposed initially by Coffin, Welder, and Glanzman (1971). The hydrologic system, as proposed, consists of two aquifers separated by a confining layer.

The upper aquifer consists of the saturated rocks above the Mahogany zone, and the lower aquifer consists of the permeable, saturated rocks below the Mahogany zone. The lower aquifer is considered to be confined by the Mahogany zone, which acts as a leaky confining layer. The Douglas Creek and Garden Gulch Members and the saline zone are relatively impermeable and form the base of this hydrologic system.

\section{FRACTURING}

The marlstones in the Parachute Creek Member of the Green River Formation have little or no primary porosity. Wide variations in hydraulic properties exist over short distances because fractures, solution cavities, and collapse breccia are the main source of secondary porosity and permeability (Weeks and others, 1974). The lean marlstones are more brittle than the rich marlstones and, thus, tend to be more fractured and more permeable than the rich units. Onsite observations indicate that vertical fractures may be confined to particular beds or layers, or may pass vertically through many beds or layers. The primary direction of fracturing is approximately west northwest as indicated by the mapped surficial fracturing in the area (fig. 3) and by the work of Wolff, Bredehoeft, Keys, and Shuter (1974). Onsite observations by G. J. Saulnier, Jr., and the work of Welder (1971) indicate the existence of an extensive network of surficial joints and minor faults subordinate to the major faults in the area. The alinement of individual fractures varies from normal to subparallel to the strike of the major faults (fig. 3). The fracture permeability that occurs in wells located away from the major fault zones indicates that joints and minor faults may occur at depth in a pattern analogous to that indicated at the surface.

The alinement of the major fracture systems is similar to the alinement of the structural trough at the base of the leached zone and the alinement of the surface-water drainage system. The tectonic activity that shaped the Piceance basin may have affected the distribution of fracture permeability in the bed- rock aquifers and predisposed the surface-water drainage system to erode channels either along or perpendicular to the structure and major fracture alinement.

\section{AQUIFER LIMITS}

The aquifer system is truncated by topography on the eastern, northern, and western margins of the basin where the water-bearing units crop out. The southern boundary of the study area coincides with a ground-water divide extending along the Roan Plateau to Cathedral Bluffs (Coffin and others, 1971). South of this divide, ground water flows toward the Colorado River. North of this divide, ground water flows toward Piceance and Yellow Creeks, the two major streams draining the study area. The lateral extent of the aquifers considered in this study coincides with the area studied by Weeks, Leavesley, Welder, and Saulnier (1974).

\section{ELEVATION AND THICKNESS OF BEDDING IN AQUIFERS}

The vertical variations in potentiometric head and ground-water quality that occur in Piceance basin prompted the authors to use a five-layer system to describe the hydrology and geochemistry (fig. 2). Each of the layers was subsequently represented as a layer in a mathematical model of the ground-water system.

Layer 1 consists of the saturated part of the Uinta Formation. The base of layer 1 slopes toward the northwestern part of the basin and ranges in elevation from about 5,500 toabout $8,000 \mathrm{ft}$ (fig. 4). The saturated thickness of layer 1 exceeds $800 \mathrm{ft}$ in the northwestern part of the basin and diminishes to zero around a structural high between Piceance Creek and Dry Fork, and around the basin margins (fig. 5).

Layer 2 consists of the saturated part of the Parachute Creek Member above the Mahogany zone. The base of layer 2 (top of the Mahogany zone) slopes toward two structural lows in the northwestern and central parts of the basin and ranges in elevation from about 5,000 to about $8,000 \mathrm{ft}$ (fig. 6). The saturated thickness of layer 2 varies from zero to more than $400 \mathrm{ft}$ in the southern and central parts of the basin (fig. 7).

Layer 3 consists of the saturated part of the Mahogany zone. The saturated thickness of layer 3 varies from less than 100 to more than $225 \mathrm{ft}$ and is the most uniformly thin layer considered in this study (fig. 8).

Layer 4 extends from the base of the Mahogany zone to the base of a rich oil-shale unit designated R-6 by Cashion and Donnell (1972) and Dyni (1974). The saturated thickness of layer 4 varies from less than $125 \mathrm{ft}$ in the southwestern part of the basin to 
EXPLANATION

STRIKE OF MAJOR FAULT OR FAULT

ZONE - Modified from Duncan (1976a-f),

Hail (1970, 1973, 1974a, b, 1975, 1977),

O'Sullivan (1974), Pipiringos and

Johnson (1976), Roehler (1972), and

Ziemba (1974)

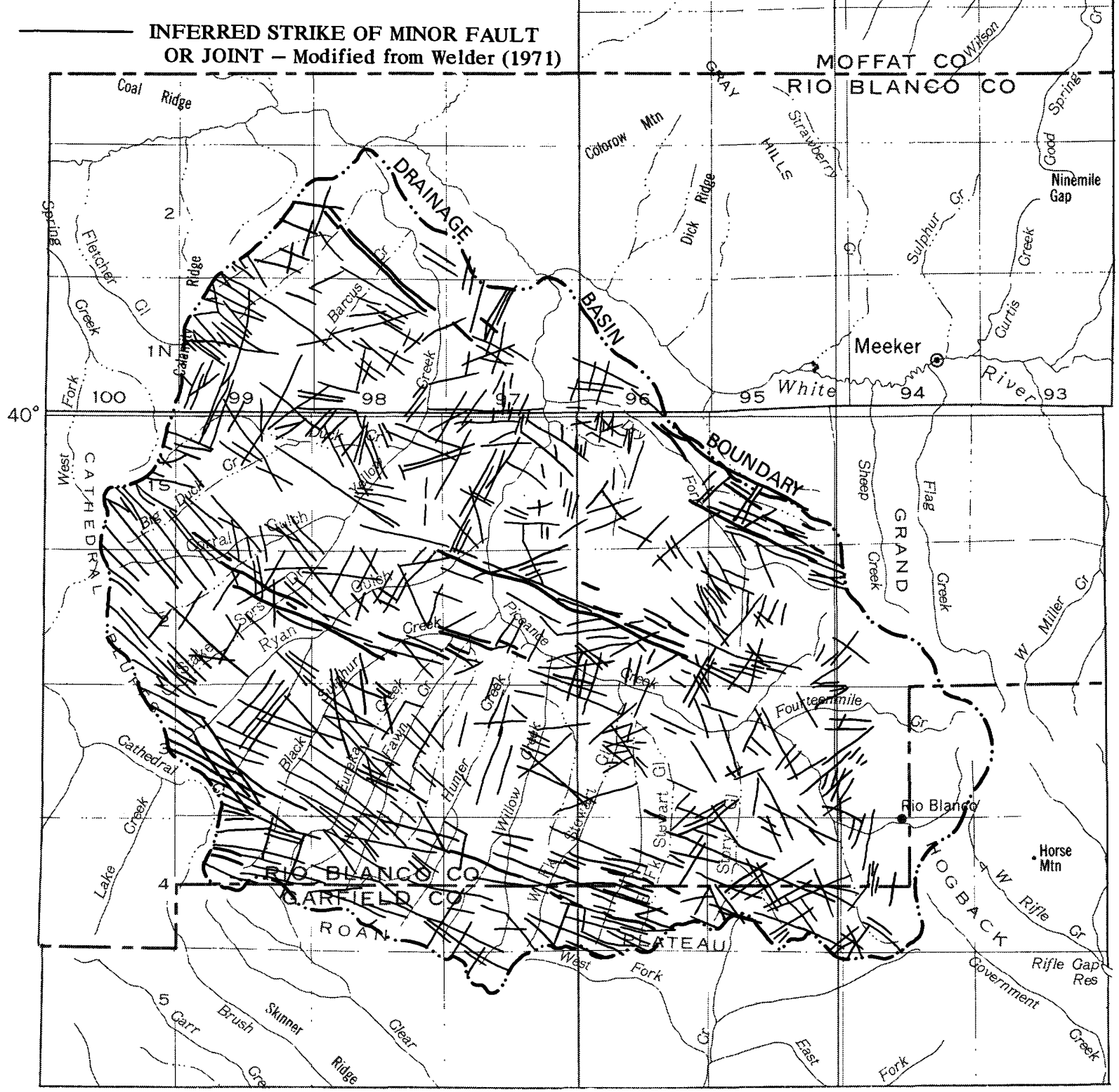

Base from U. S. Geological Survey

State base map, 1969

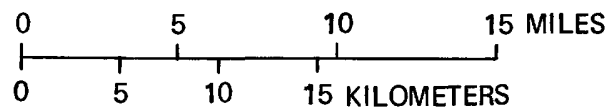

Figure 3.-Extent of surficial fracturing.

more than $250 \mathrm{ft}$ in the northwestern part of the basin (fig. 9).

Layer 5 extends from the base of the R- 6 zone to the base of the water-bearing materials in the basin. The base of layer 5 ranges in elevation from about 4,250 to about 7,500 ft (fig. 10). Thus, a difference of about $3,250 \mathrm{ft}$ exists between the structural high at the western margin of the basin and the structural low in the north-central part of the basin. The asymmetry of the ground-water basin is apparent as is the extent 


\section{EXPLANATION}

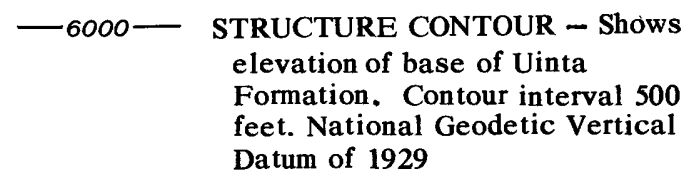

- WELL

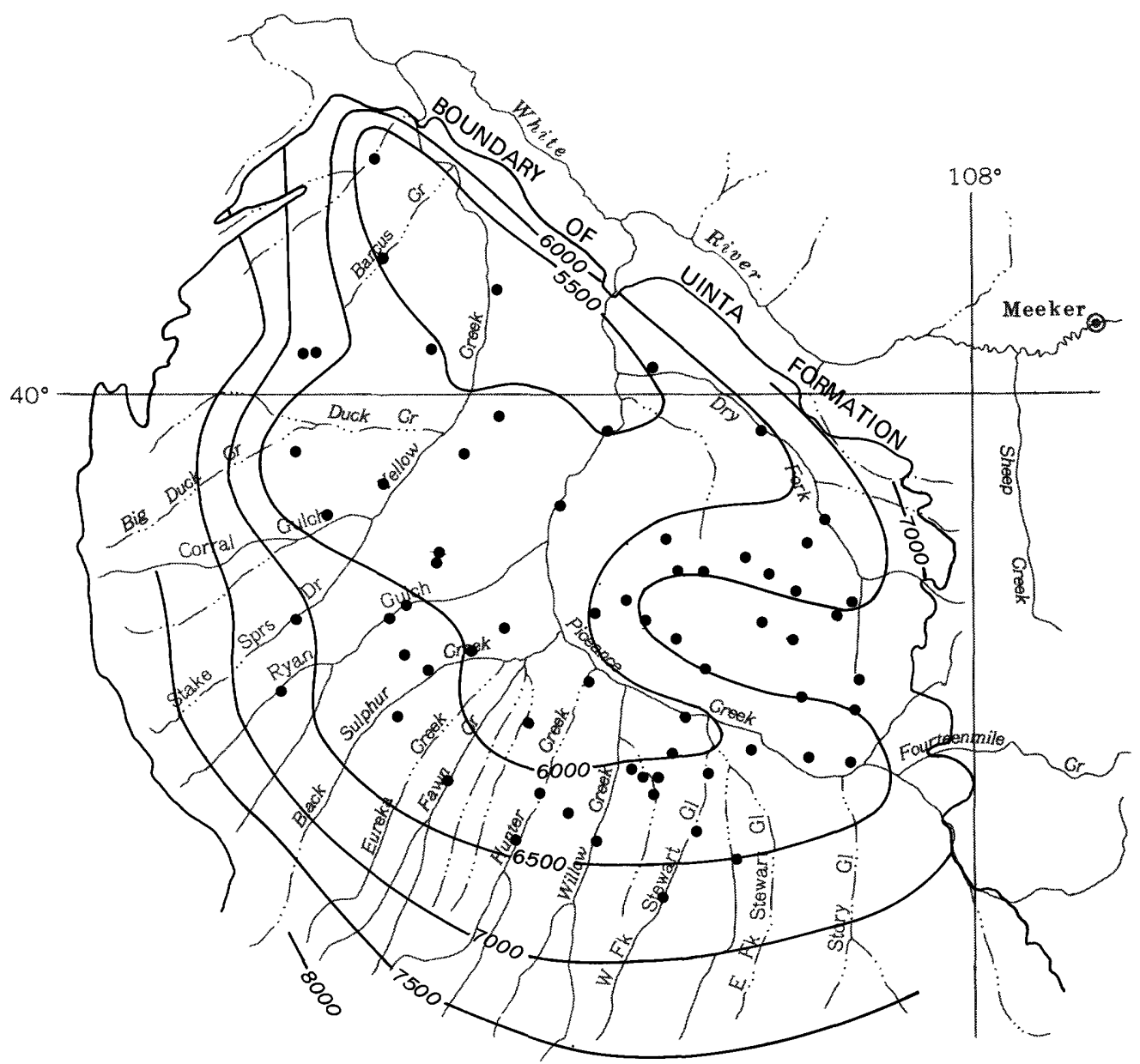

Base from U. S. Geological Survey State base map, 1969

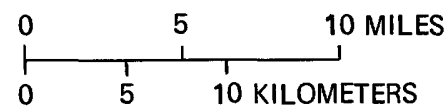

FiguRE 4.-Structure contours on the base of the Uinta Formation.

of the structural high located in the east-central part of the basin. The saline zone is found in a $340-\mathrm{mi}^{2}$ area in the central part of the basin (fig. 10). The saturated thickness of layer 5 varies from zero near the outcrops to more than $1,000 \mathrm{ft}$ in the northeastern part of the basin (fig. 11).

The total saturated thickness of the five layers exceeds $2,000 \mathrm{ft}$ in the northeastern part of the basin and generally exceeds $1,500 \mathrm{ft}$ throughout most of the central part of the basin. Saturated thickness in- creases rapidly from zero at the outcrops to more than $1,000 \mathrm{ft}$ near the eastern, northern, and western margins of the basin.

The aquifer terminology used by Coffin, Welder, and Glanzman (1971) and Weeks, Leavesley, Welder, and Saulnier (1974) correlates with the layers described above. Layers 1 and 2 represent the upper aquifer, layer 3 represents the leaky confining layer, and layers 4 and 5 represent the lower aquifer. 


\section{EXPLANATION}

$-200-$ LINE OF EQUAL SATURATED

THICKNESS - In terval 200

feet

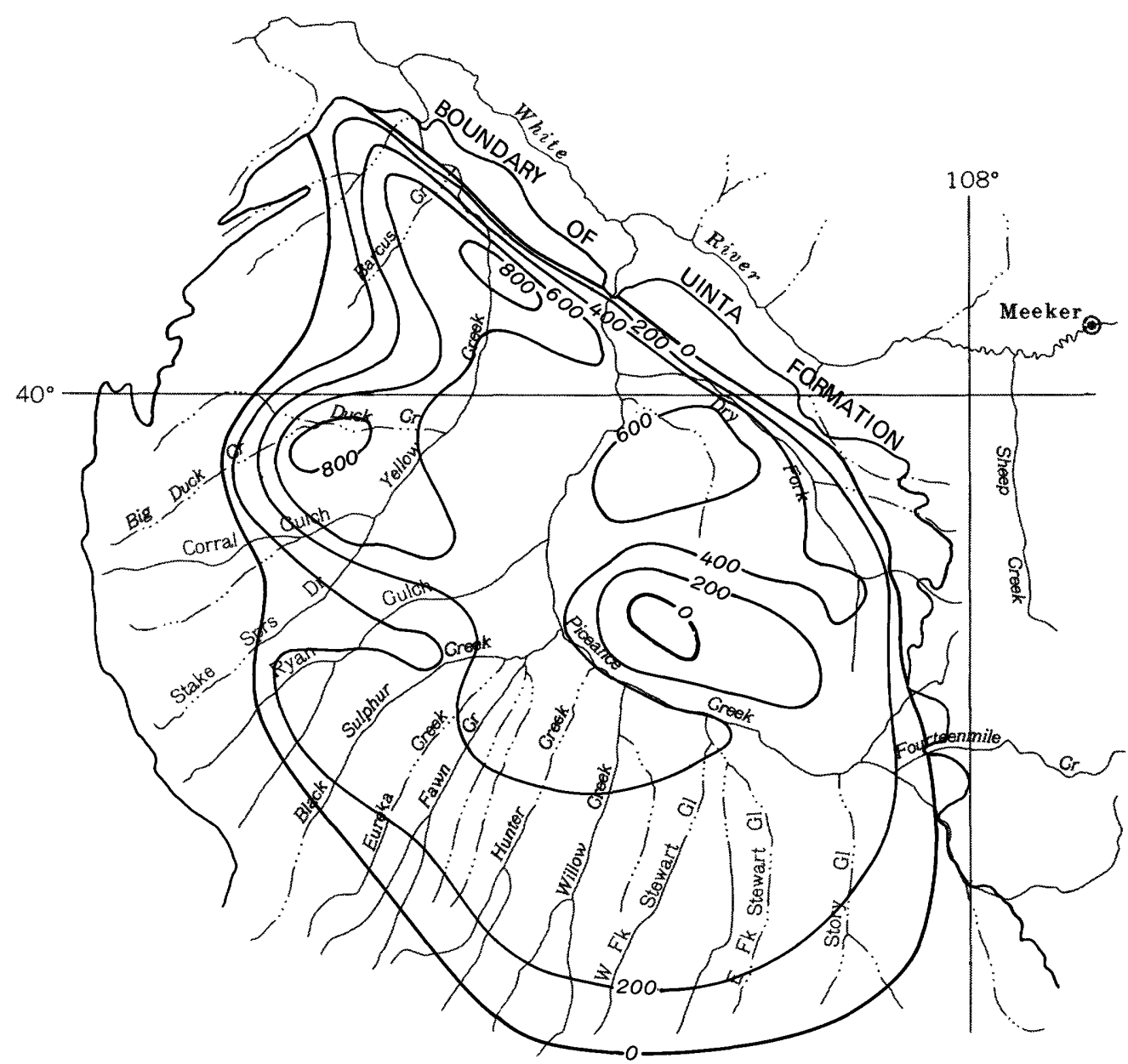

Base from U. S. Geological Survey

State base map, 1969

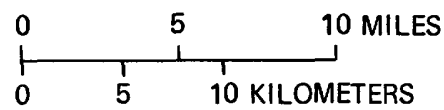

FIGURE 5.-Saturated thickness of the Uinta Formation.

\section{HYDRAULIC CONDUCTIVITY}

The mathematical model chosen to simulate the hydrology and water quality in the Piceance basin required a more detailed areal and vertical distribution of hydraulic conductivity than had been presented in reports of earlier studies. New estimates of lateral and vertical hydraulic conductivity were made using data presented by Ficke, Weeks, and Welder (1974); Weeks and Welder (1974); Weeks, Leavesley,
Welder, and Saulnier (1974); Wright Water Engineers, Inc. (1975); Ashland Oil, Inc., and Shell Oil Co., Operator (1976); Campbell (1977); and Dale and Weeks (1978); as well as unpublished data on aquifer tests performed by F. A. Welder, J. B. Weeks, and G. J. Saulnier, Jr. Data from these sources and other information on the structure, stratigraphy; and faulting in the basin were used by the authors to construct maps of the horizontal and vertical hydraulic conductivity of each layer. Where aquifer tests or other 


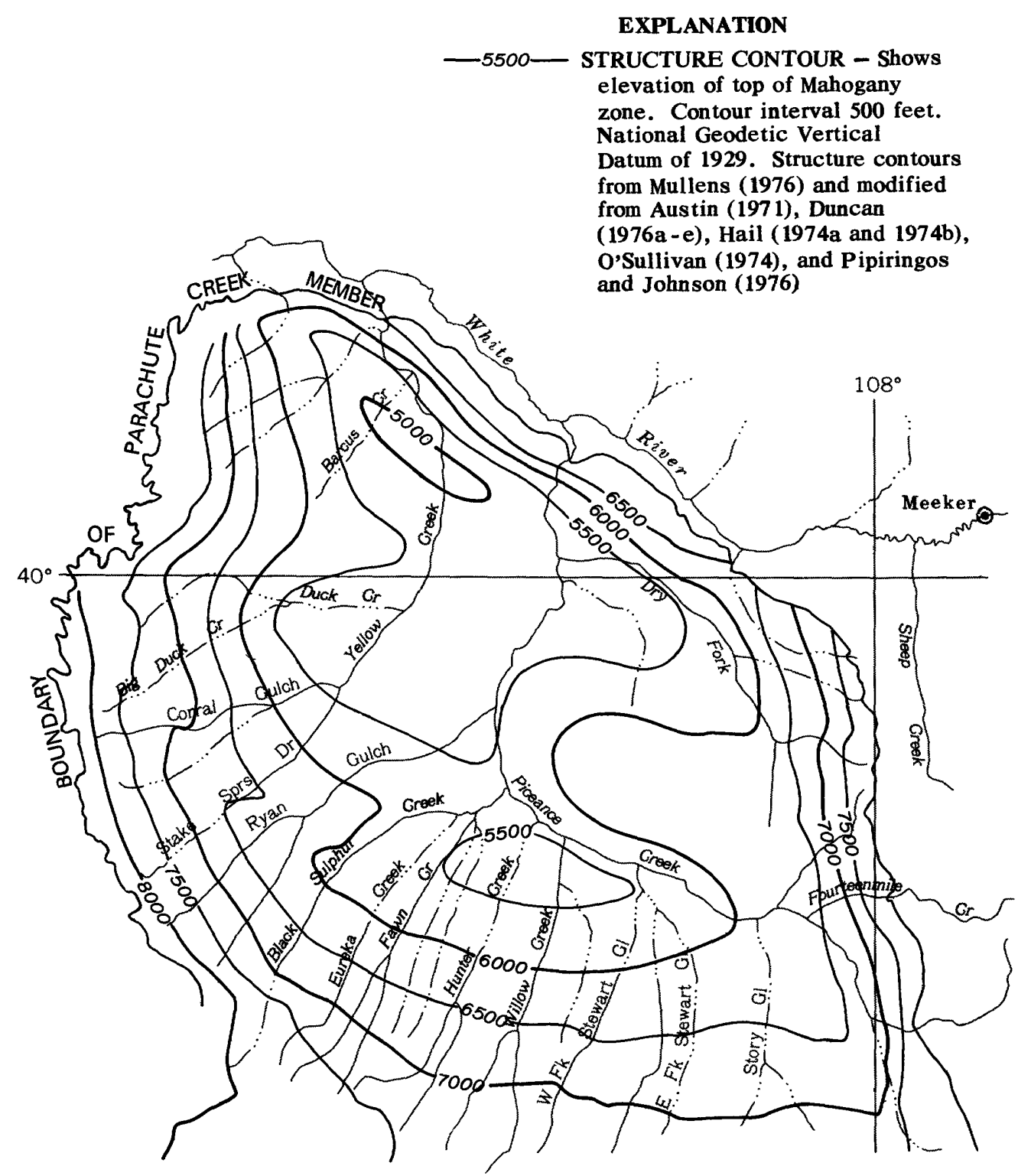

Base from U. S. Geological Survey State base map, 1969

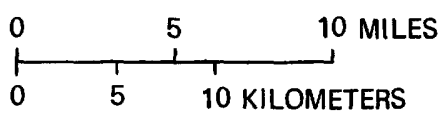

Figure 6.-Structure contours on the top of the Mahogany zone.

data were of sufficient density, hydraulic conductivity was estimated on a node by node basis. In less well-defined areas, only general estimates of the hydraulic conductivity over large areas were justified.

The nonhomogeneous character of the fractured aquifer makes determination of average aquifer characteristics based on scattered data points extremely difficult. As a result, the initial estimates of hydraulic conductivity were modified somewhat based on results of the model calibration. Although the resulting hydraulic conductivity distributions produce reasonable model results, it must be emphasized that the distributions are only estimates and, due to the complexity of the fractured aquifers, may not be unique in that a different distribution of hydraulic conductivity might be found that also produces reasonable model results and agrees with the hydrologic data. The lateral and vertical hydraulic 


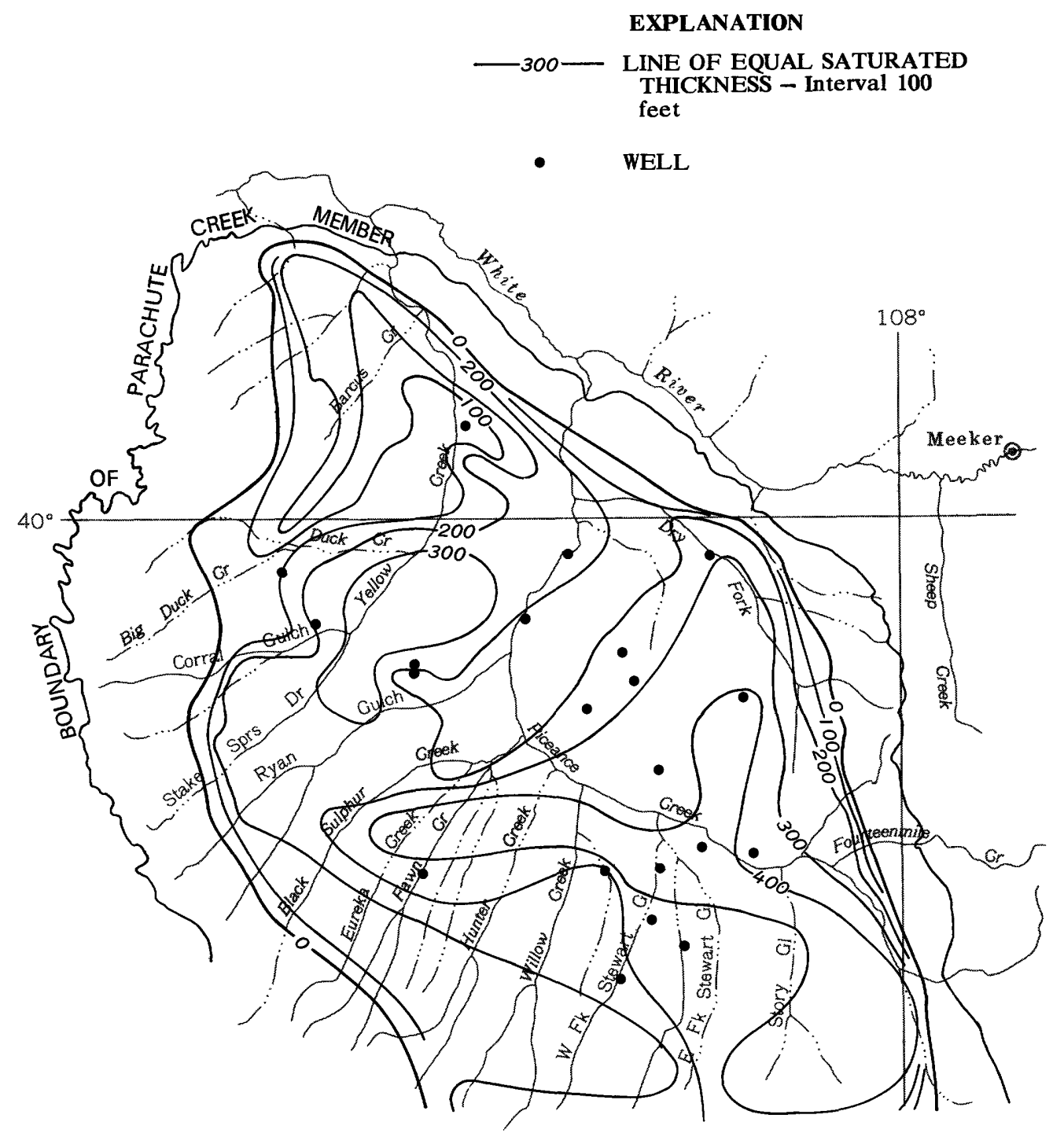

Base from U. S. Geological Survey State base map, 1969

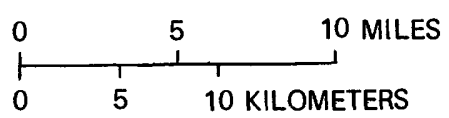

FigurE 7.-Saturated thickness of the Parachute Creek Member above the Mahogany zone.

conductivities estimated for each of the five layers are shown in figures 12-17. The figures indicate lateral hydraulic conductivities of as much as 2.0 $\mathrm{ft} / \mathrm{d}$ along Piceance Creek and in the north-central part of the basin. Lateral hydraulic conductivities around the margins of the basin range from 0.1 to 0.6 $\mathrm{ft} / \mathrm{d}$. Vertical hydraulic conductivities as small as $7 \times$ $10^{-4} \mathrm{ft} / \mathrm{d}$ occur in the Mahogany zone (layer 3) with values as much as $1.0 \mathrm{ft} / \mathrm{d}$ in layers 2,4 , and 5 .

Aquifer-test data (Ashland Oil, Inc., and Shell Oil Co., Operator, 1976, and Sokol, 1976) and work by Campbell (1977) indicate that the aquifers are non- homogeneous and anisotropic as is shown in figures 12-17. This is due to the differences in the response of the rocks to fracturing and is related to the distribution of rich and lean zones and the presence or absence of solution cavities and collapse breccia. Insufficient data exist to estimate the lateral anisotropy in layers 1, 3, 4, and 5; as a result, these layers were assumed to be isotropic [hydraulic conductivity in the $x$-direction $\left(K_{x}\right)=$ hydraulic conductivity in the $y$-direction $\left.\left(K_{y}\right)\right]$. A ratio of $K_{x}$ to $K_{y}$ of 1.1 was estimated for all of layer 2 based on the work of Campbell (1977). The ratio of lateral $\left(K_{x}\right)$ to vertical 
EXPLANATION

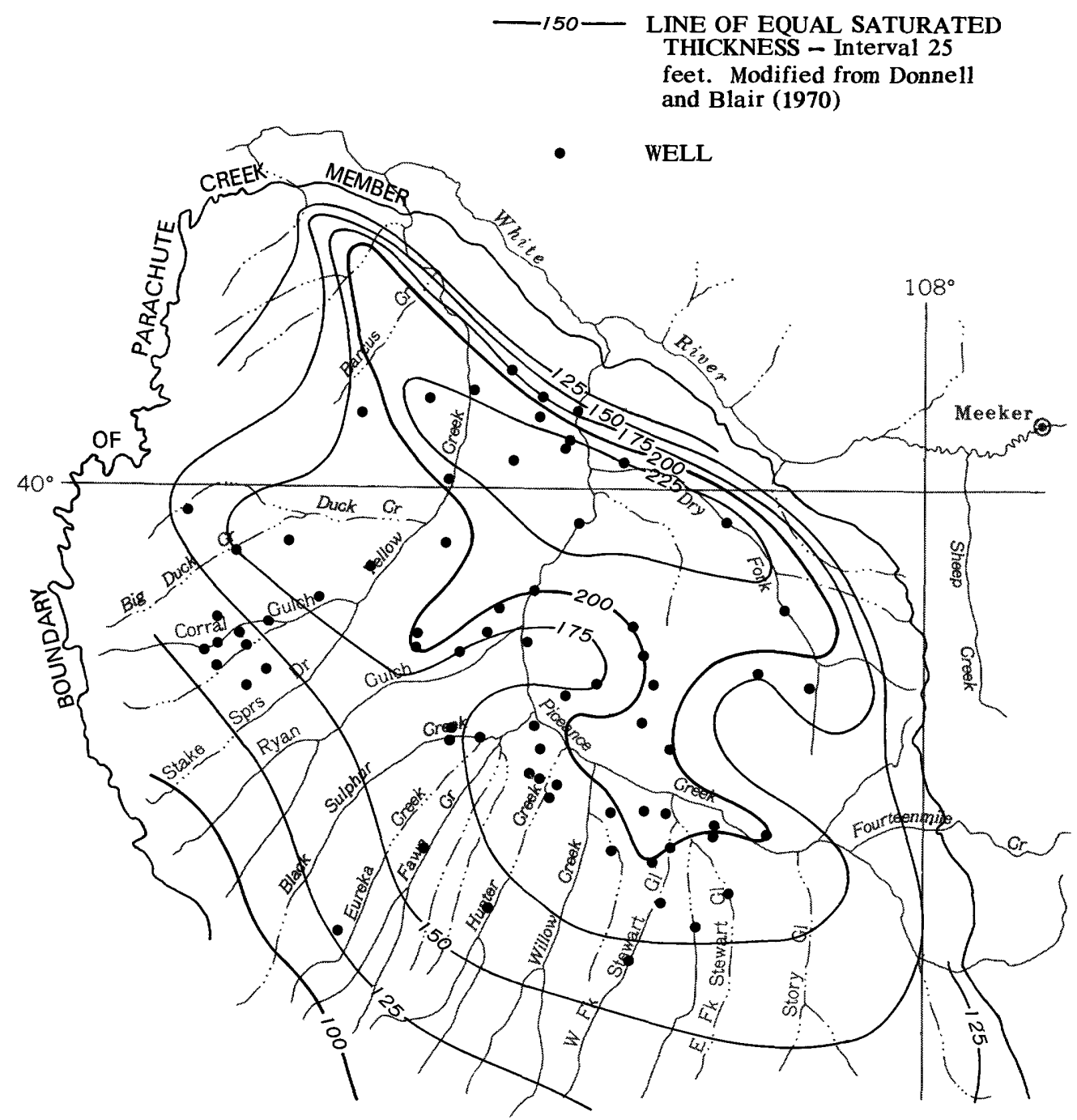

Base from U. S. Geological Survey

State base map, 1969

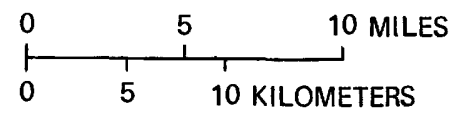

Figure 8.-Saturated thickness of the Malogany zone.

$\left(K_{z}\right)$ hydraulic conductivity varies from 2 in layers 1 and 2 to as much as 100 in layer 3 , and 500 in layers 4 and 5 .

\section{POROSITY AND COMPRESSIBILITY}

Few data have been collected to determine the porosity and compressibility of the rocks in Piceance basin. Aquifer tests of unfractured sections in the saline zone performed in 1973 (Wolff and others, 1974) and 1976 (Dale and Weeks, 1978) indicate that these sections are virtually impermeable and likely have little effective porosity. By contrast, relatively large porosities occur as a result of voids in collapse breccia and solution cavities.

Porosity estimates by the authors and by Banks and Franciscotti (1976) have been made by solving an equation (Lohman, 1972, p. 9) relating porosity to the storage-coefficient data obtained from aquifer tests in Piceance basin. This technique resulted in varied porosity estimates. From such results, Banks and his coworkers estimated the porosity in the Parachute Creek Member of the Green River Formation to be between 2 and 4 percent. A porosity of 1.6 percent was obtained from an analysis of a core 


\section{EXPLANATION}

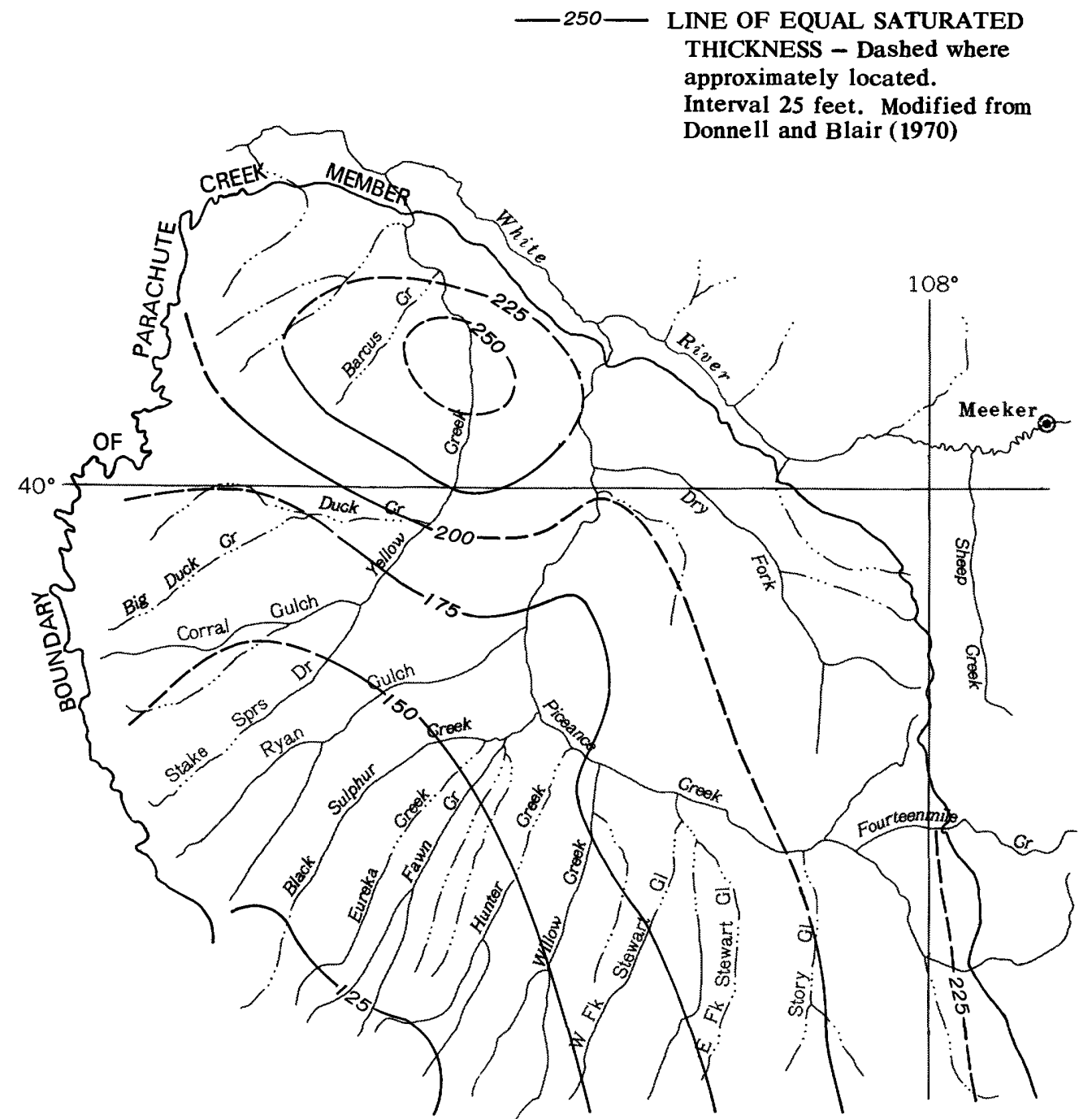

Base from U. S. Geological Survey State base map, 1969

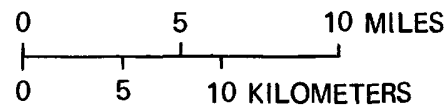

FIGURE 9.-Saturated thickness of the interval from the base of the Mahogany zone to the base of the R- 6 zone.

sample collected by Campbell and Olhoeft (1977). In an effort to use a reasonable yet conservative estimate of basinwide porosity, the authors chose a value of 1 percent. A small value of porosity was chosen so the rate of ground-water movement shown by subsequent modeling would not be too conservative and, thus, cause the potential for degradation of ground-water quality around the simulated mine tracts to be underestimated. About 6.7 million acre-ft of ground water are in storage in the Green River and
Uinta Formation aquifers in the basin if the average porosity of the formations is 1 percent. If the average porosity is 4 percent, the volume of water in storage would be about 27 million acre-ft. Better data on the porosity of the aquifers'are needed before a more accurate estimate of the volume of ground water in storage can be made.

Podio (1968) determined that the compressibility of water-saturated oil shale from the Green River Formation ranged from $2.6 \times 10^{-7}$ to $2.85 \times 10^{-7} \mathrm{in}^{2} / \mathrm{lb}$ 


\section{EXPLANATION}

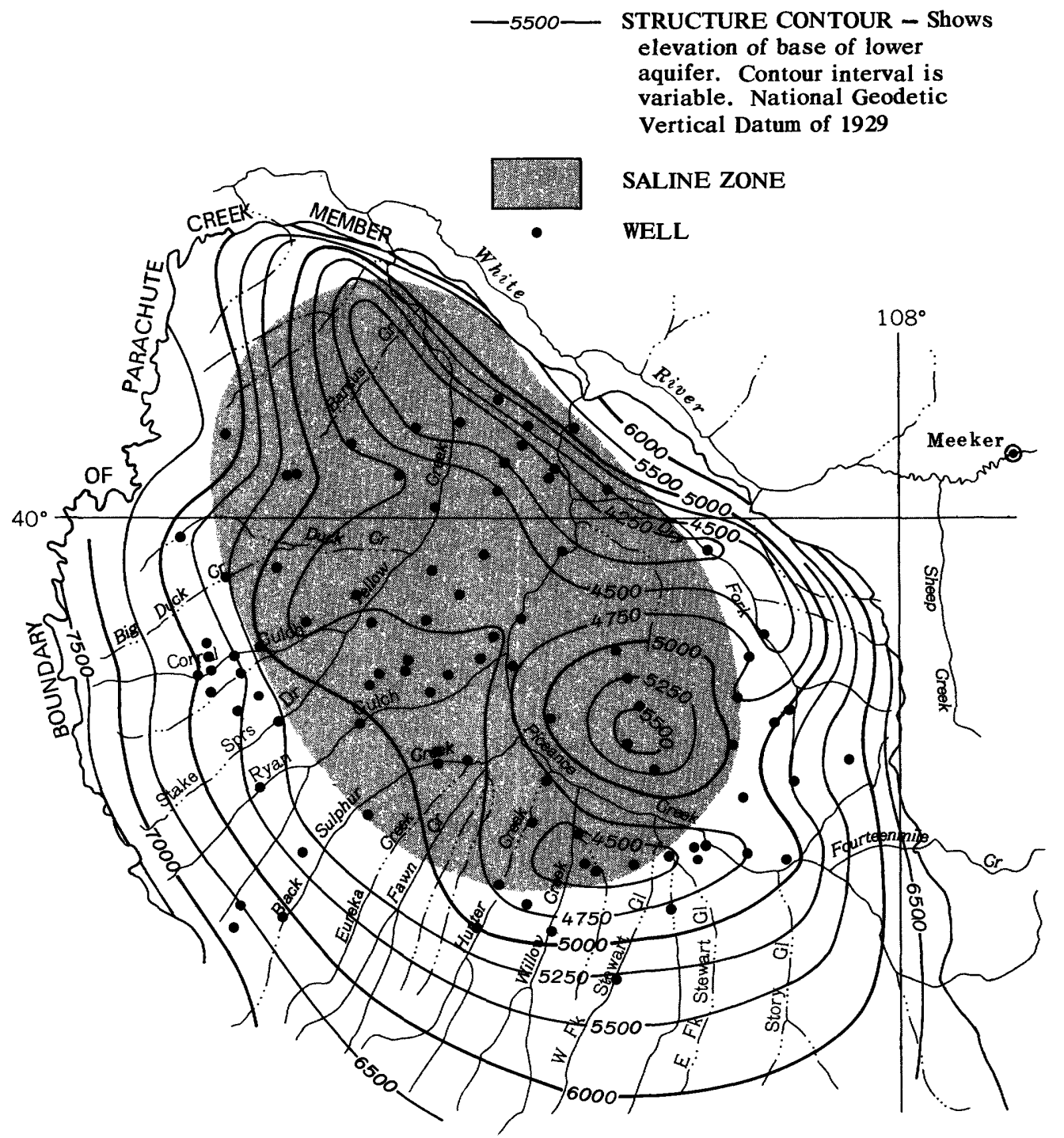

Base from U. S. Geological Survey State base map, 1969

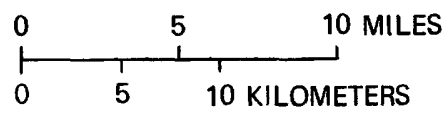

Figure 10.-Structure contours on the base of the lower aquifer.

under confining pressures ranging from 0 to 10,000 $\mathrm{lb} / \mathrm{in}^{2}$. Using these formation compressibilities, a porosity of 1 percent and water compressibility of $3.1 \times 10^{-6} \mathrm{in}^{2} / \mathrm{lb}$, the specific storage of the oil-shale aquifers was calculated to be $1.3 \times 10^{-7}$ per foot using equations of DeWiest (1969, p. 15). This compares favorably with the mean specific storage of $5 \times 10^{-7}$ per foot calculated from the storage-coefficient data presented by Weeks, Leavesley, Welder, and Saulnier (1974, p. 28).

\section{GROUND-WATER RECHARGE, DISCHARGE AND POTENTIOMETRIC HEADS}

The part of the Piceance structural basin considered in this investigation is a closed ground-water basin in which no cross-boundary flow of ground water occurs. Infiltrating precipitation is the principal source of ground-water recharge. This recharge causes both downward and lateral ground-water movement toward the north-central part of the basin. In 
EXPLANATION

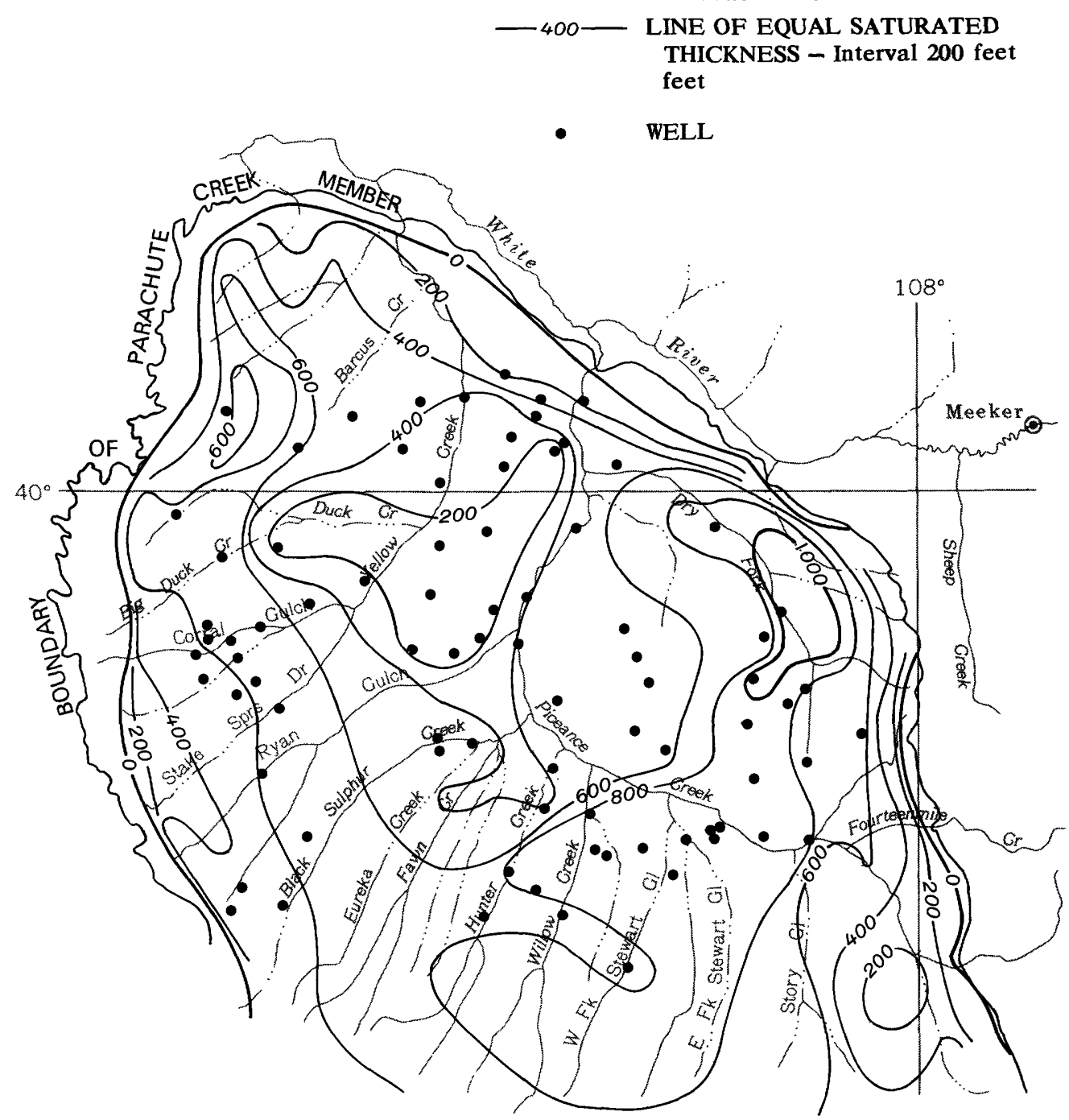

Base from U. S. Geological Survey State base map, 1969

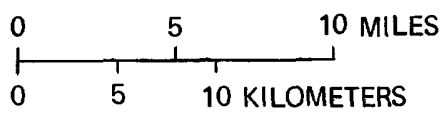

FIGURE 11.-Saturated thickness of the Parachute Creek Member below the base of the R-6 zone.

the central part of the basin, potentiometric-head gradients are opposite those near the basin margins and ground water moves upward from deeper to shallower strata, ultimately discharging into Piceance and Yellow Creeks and their tributaries. Some ground water also is discharged by evapotranspiration from vegetation and wetlands in the stream valleys. Comprehensive descriptions and estimates of the sources and rates of recharge to and discharge from the aquifers in Piceance basin have been reported (Weeks and others, 1974). The reported estimates generally were used in this investigation and are reviewed briefly to provide continuity in this report. 


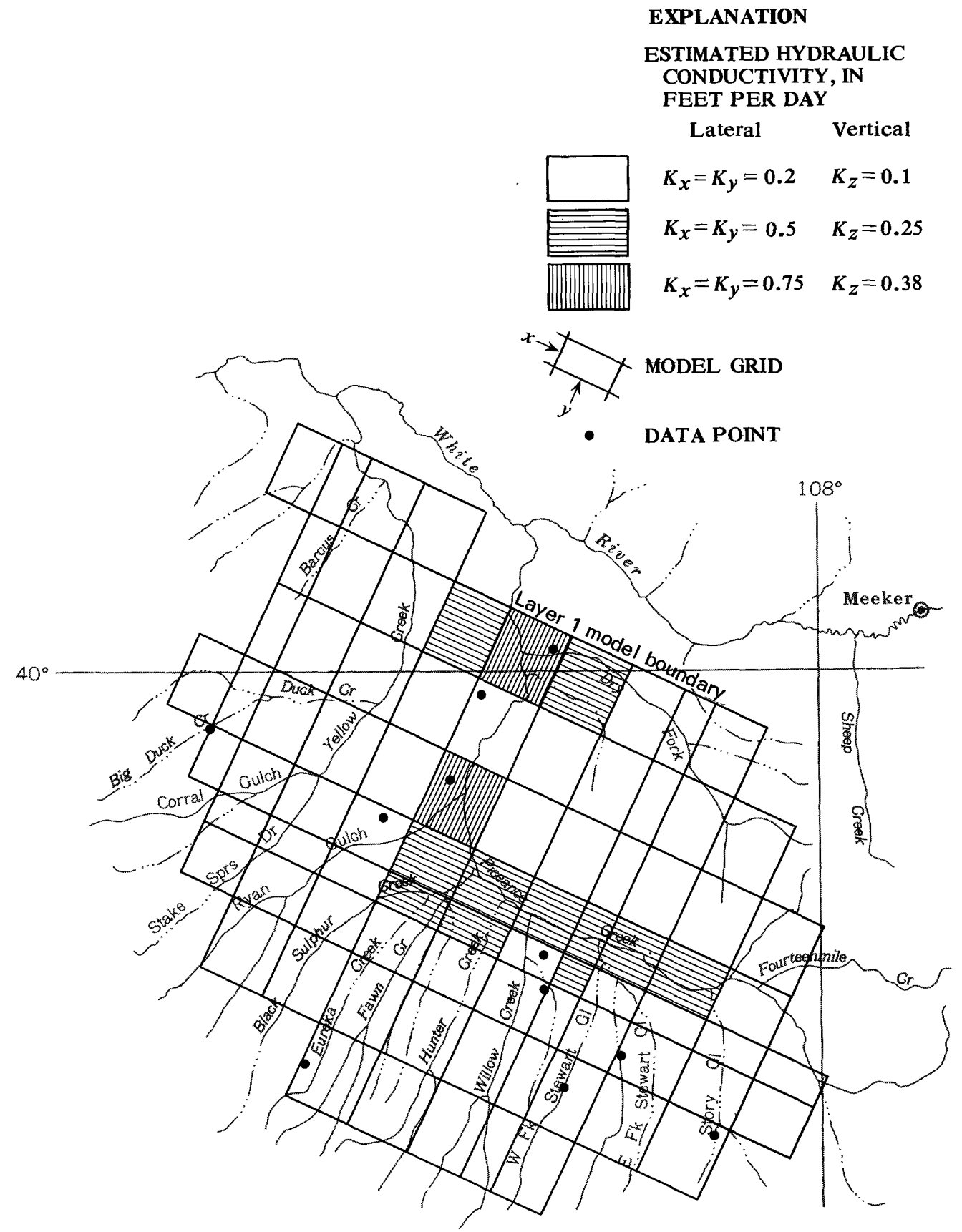

Base from U.S. Geological Survey State base map, 1969

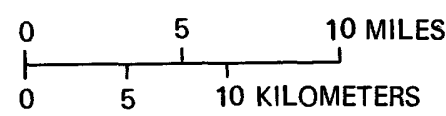

FIGURE 12.-Lateral and vertical hydraulic conductivity for layer 1. 


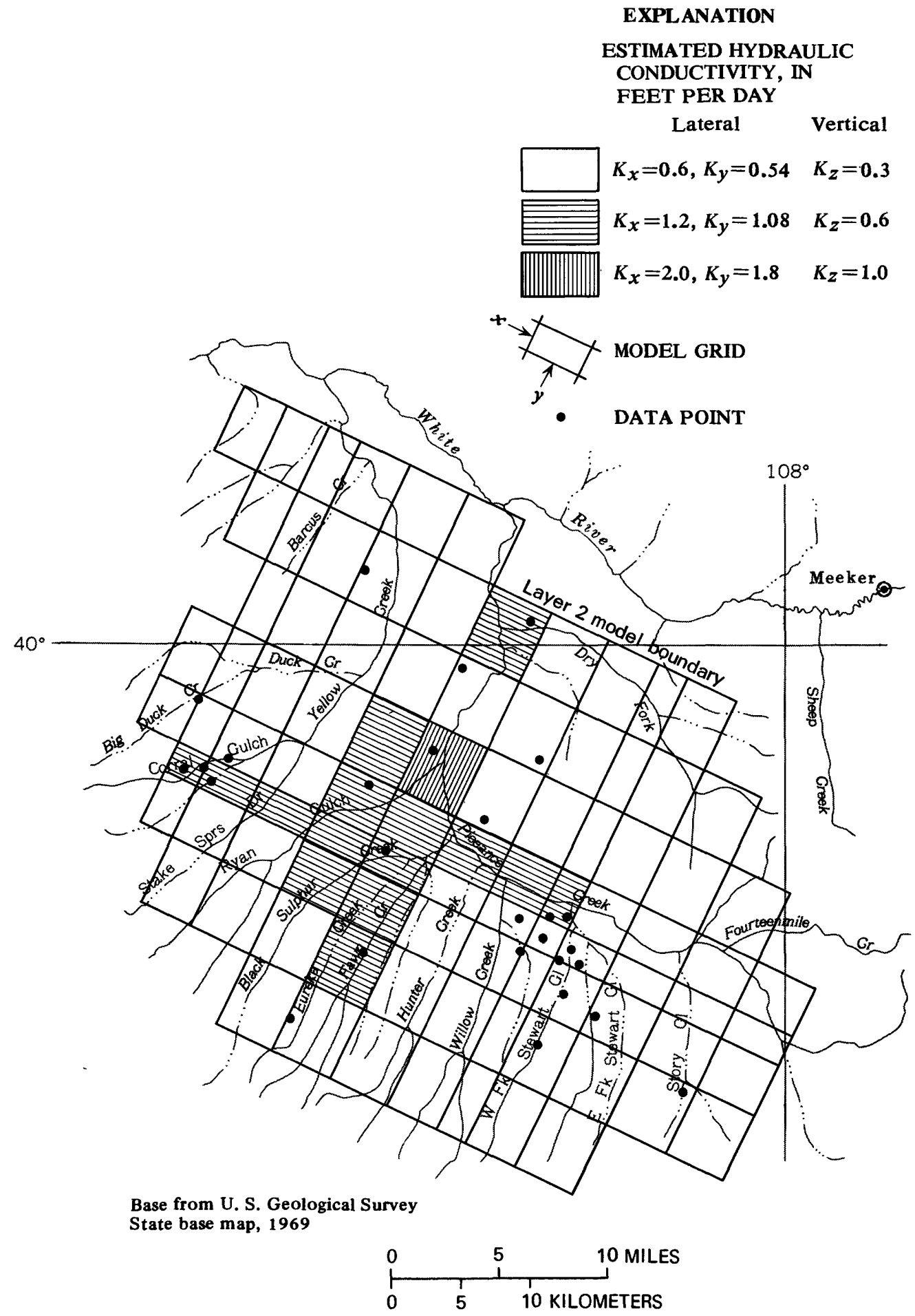

FIGURE 13.-Lateral and vertical hydraulic conductivity for layer 2.

GROUND-WATER RECHARGE AND DISCHARGE

Weeks, Leavesley, Welder, and Saulnier (1974) estimated that the principal source of ground-water recharge was snowpack melt water in areas with ele- vations greater than 7,000 ft. An estimated 33 to 36 $\mathrm{ft}^{3} / \mathrm{s}$ of aggregate recharge occurs either as direct infiltration into the bedrock aquifers or by recharge to small alluvial aquifers in the upper reaches of 
EXPLANATION

ESTIMATED HYDRAULIC

CONDUCTIVITY, IN

FEET PER DAY

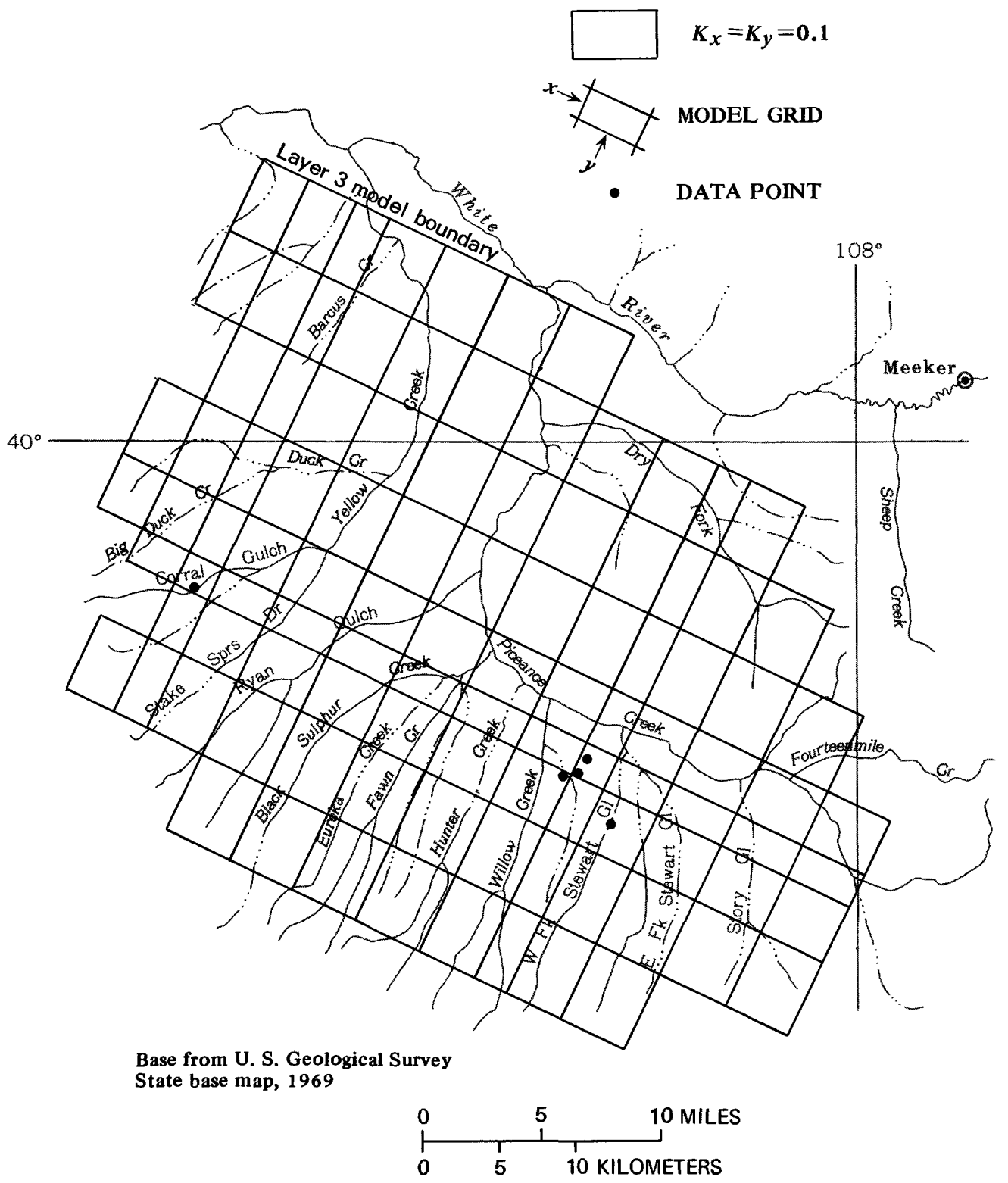

FIgURE 14.-Lateral hydraulic conductivity for layer 3.

numerous creeks, which, in turn, recharge the bedrock aquifers. The distribution of recharge is controlled by topography. Areas of higher elevation generally receive more precipitation than lower areas. As a result, the principal areas of ground-water recharge probably occur near the topographically high regions along the eastern, southern, and western margins of the basin.
Ground water discharges from the bedrock aquifers by means of: (1)Direct discharge to surface flow in Piceance and Yellow Creeks and their tributaries; (2) discharge to alluvial aquifers in the major stream valleys; and (3) by evapotranspiration from vegetation and wet soils located primarily in the stream valleys. Weeks, Leavesley, Welder, and Saulnier (1974) estimated that the aggregate discharge is between 


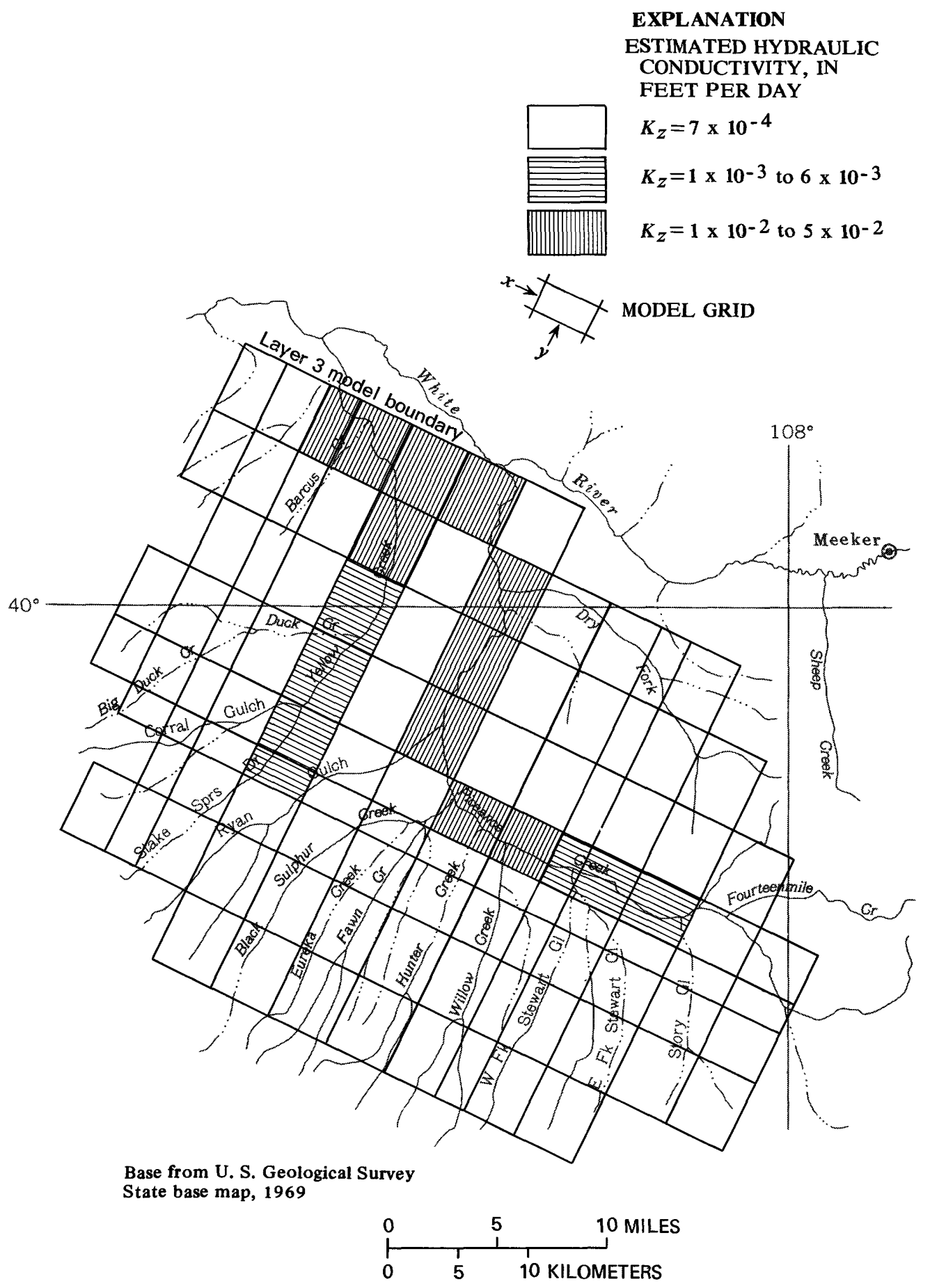

33 and $36 \mathrm{ft}^{3} / \mathrm{s}$, with 18 percent of the total discharge occurring in the Yellow Creek drainage basin and 82 percent occurring in the Piceance Creek drainage basin. About 80 percent of the surface runoff in the basin is supplied by ground-water discharge.
POTENTIOMETRIC SURFACES

Measurements of the elevation of the static water level in wells were used to construct the potentiometric-surface maps shown in figures 18 and 19 . Because of only minimal ground-water development 


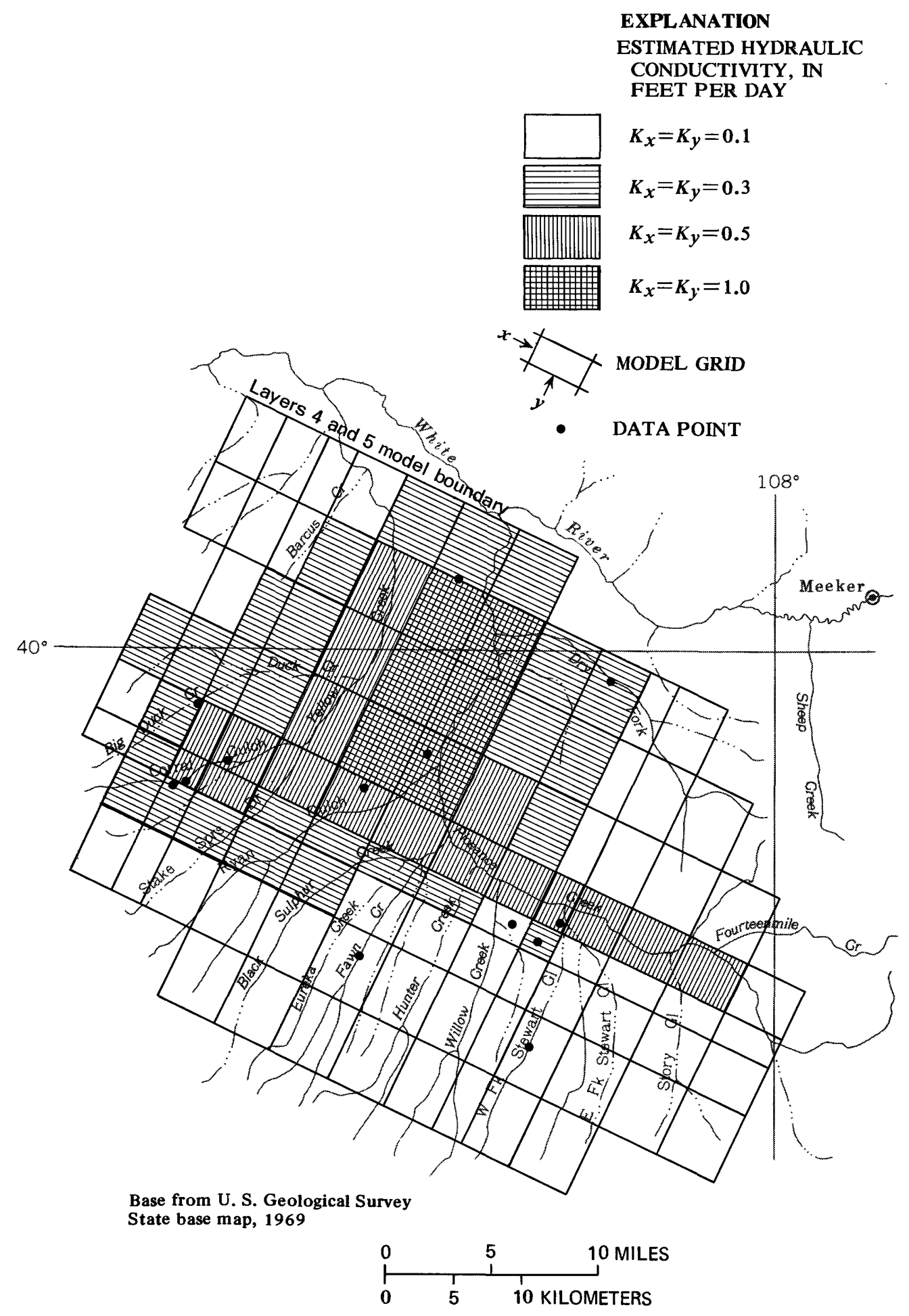

FIgURE 16.-Lateral hydraulic conductivity for layers 4 and 5.

as of 1977 , the potentiometric surfaces are representative of long-term ground-water conditions in the basin. The elevation of the potentiometric sur- face in the aquifer above the Mahogany zone (fig. 18) (layers 1 and 2) ranges from about $5,800 \mathrm{ft}$ near the mouths of Piceance and Yellow Creeks at the north- 


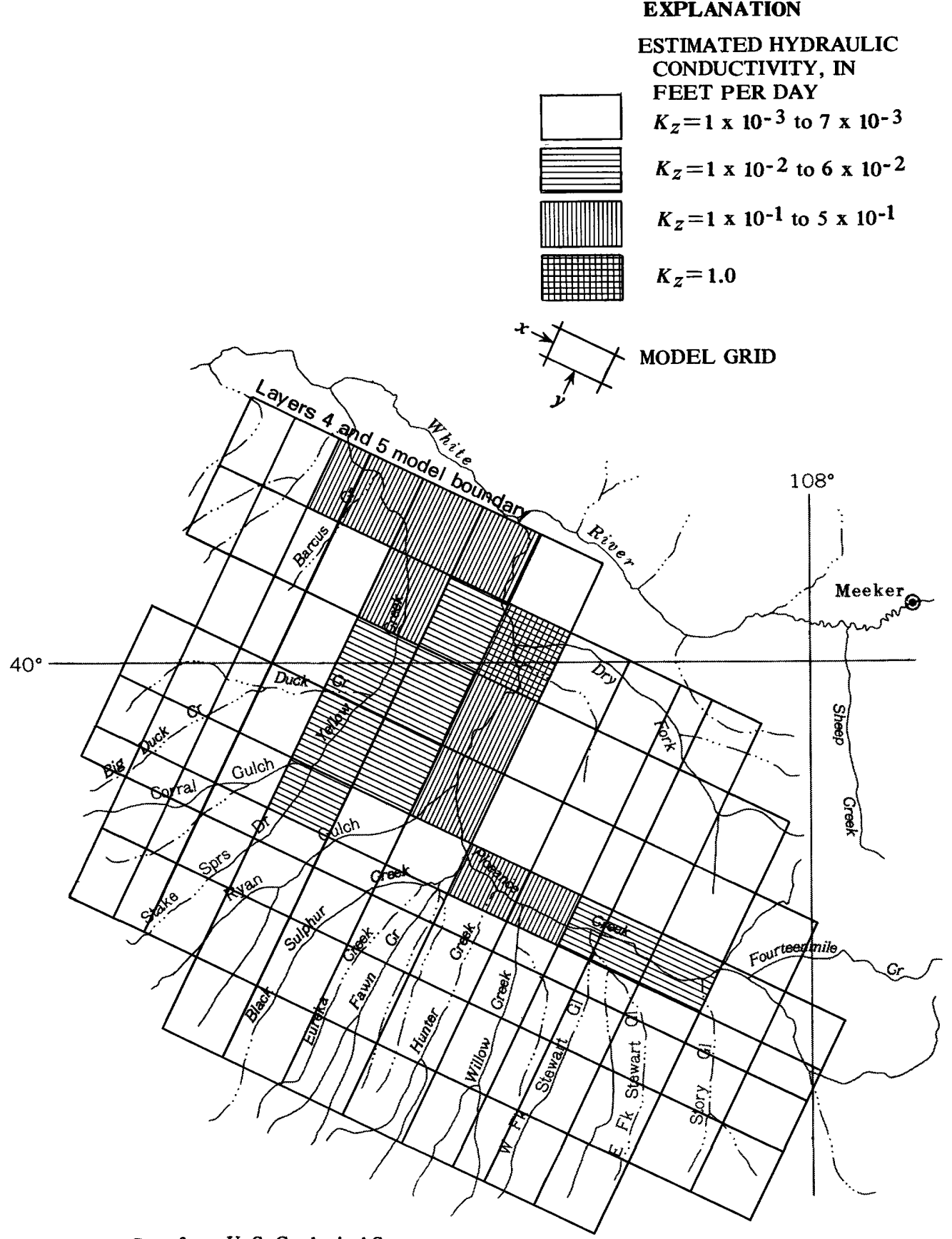

Base from U. S. Geological Survey State base map, 1969

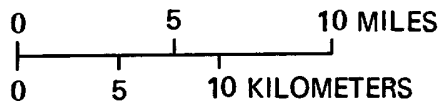

Figure 17.-Vertical hydraulic conductivity for layers 4 and 5.

ern margin of the basin, to about $7,400 \mathrm{ft}$ in the southern part of the basin. Ground-water gradients range from 20 to as much as $120 \mathrm{ft} / \mathrm{mi}$, and lateral ground-water pore velocities range from about 150 $\mathrm{ft} / \mathrm{yr}$ near the confluence of Ryan Gulch and Pice- ance Creek to about $300 \mathrm{ft} / \mathrm{yr}$ in the area south of Piceance Creek. These velocities are based on an average porosity of 1 percent and are thought by the authors to be a reasonable upper estimate of the rate of ground-water movement. 


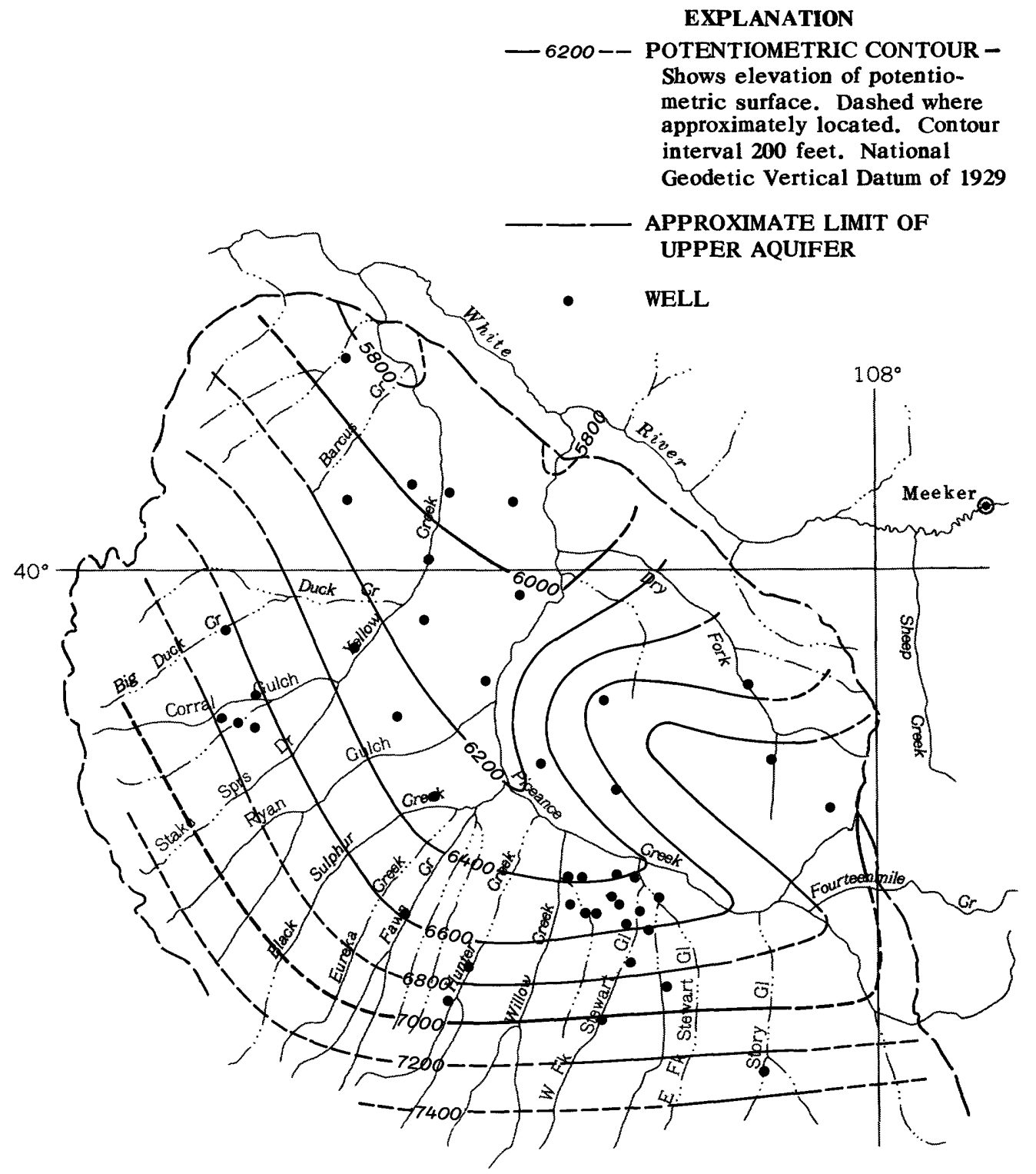

Base from U. S. Geological Survey State base map, 1969

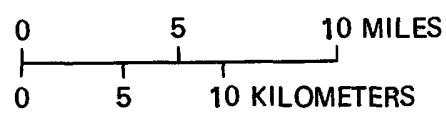

FIGURE 18.-Potentiometric surface of the upper aquifer.

The potentiometric surface in the aquifer below the Mahogany zone (fig. 19) (layers 4 and 5) is similar to that in the upper aquifer. Elevations range from about 5,800 to about $7,400 \mathrm{ft}$. Ground-water gradients range from 20 to as much as $130 \mathrm{ft} / \mathrm{mi}$, and lateral ground-water pore velocities range from about 90 $\mathrm{ft} / \mathrm{yr}$ near the confluence of Ryan Gulch and Piceance Creek to about $140 \mathrm{ft} / \mathrm{yr}$ near the confluence of Stewart Gulch and Piceance Creek.
Water moves through isotropic aquifers in a direction perpendicular to the potentiometric contours. Because the aquifers in the Piceance basin apparently are not significantly anisotropic, the direction of water movement is approximately perpendicular to the contours. On the basis of the configurations of the potentiometric surfaces, water moves from recharge areas near the basin margins toward discharge areas along Piceance Creek and the lower 


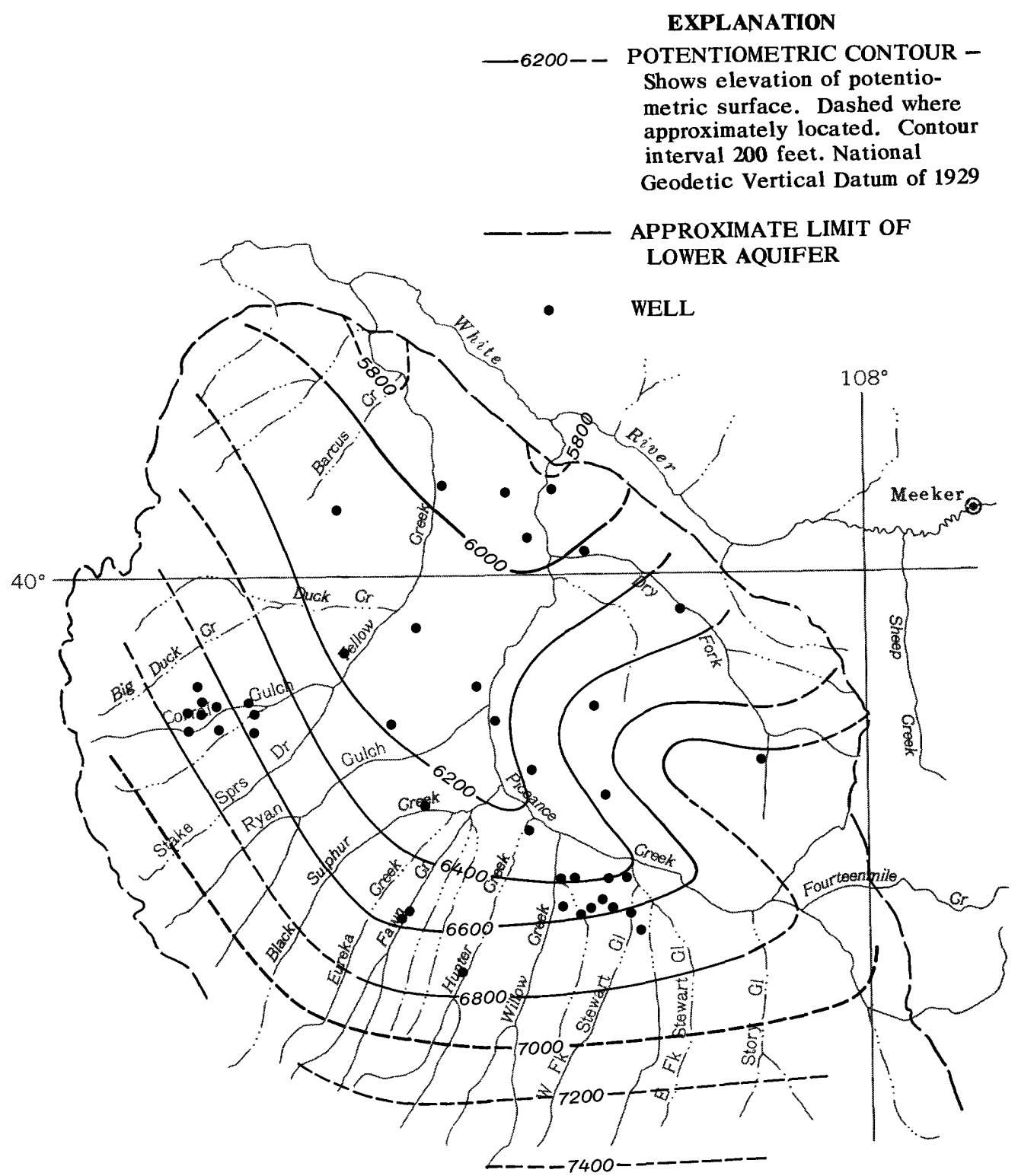

Base from U. S. Geological Survey State base map, 1969

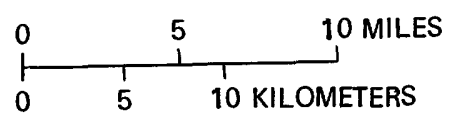

FIGURE 19.-Potentiometric surface of the lower aquifer.

reaches of Yellow Creek. The configuration of the potentiometric surfaces also indicates that water discharges along Dry Fork Creek and the downstream reaches of the creeks located between Black Sulphur and Willow Creeks.

The differences in the potentiometric heads in wells completed above and below the Mahogany zone are shown in figure 20. Potentiometric-head differences as large as $240 \mathrm{ft}$ have been measured in adjacent wells completed in the two aquifers. The pattern of potentiometric-head differences indicates that the potential for downward movement of water exists along the eastern, southern, and western margins of the basin, along the drainage divide between Piceance and Yellow Creeks, and in the area between Piceance Creek and Dry Fork. Potential for upward movement of water primarily exists along Piceance Creek and the downstream reaches of its tributaries. 
EXPLANATION

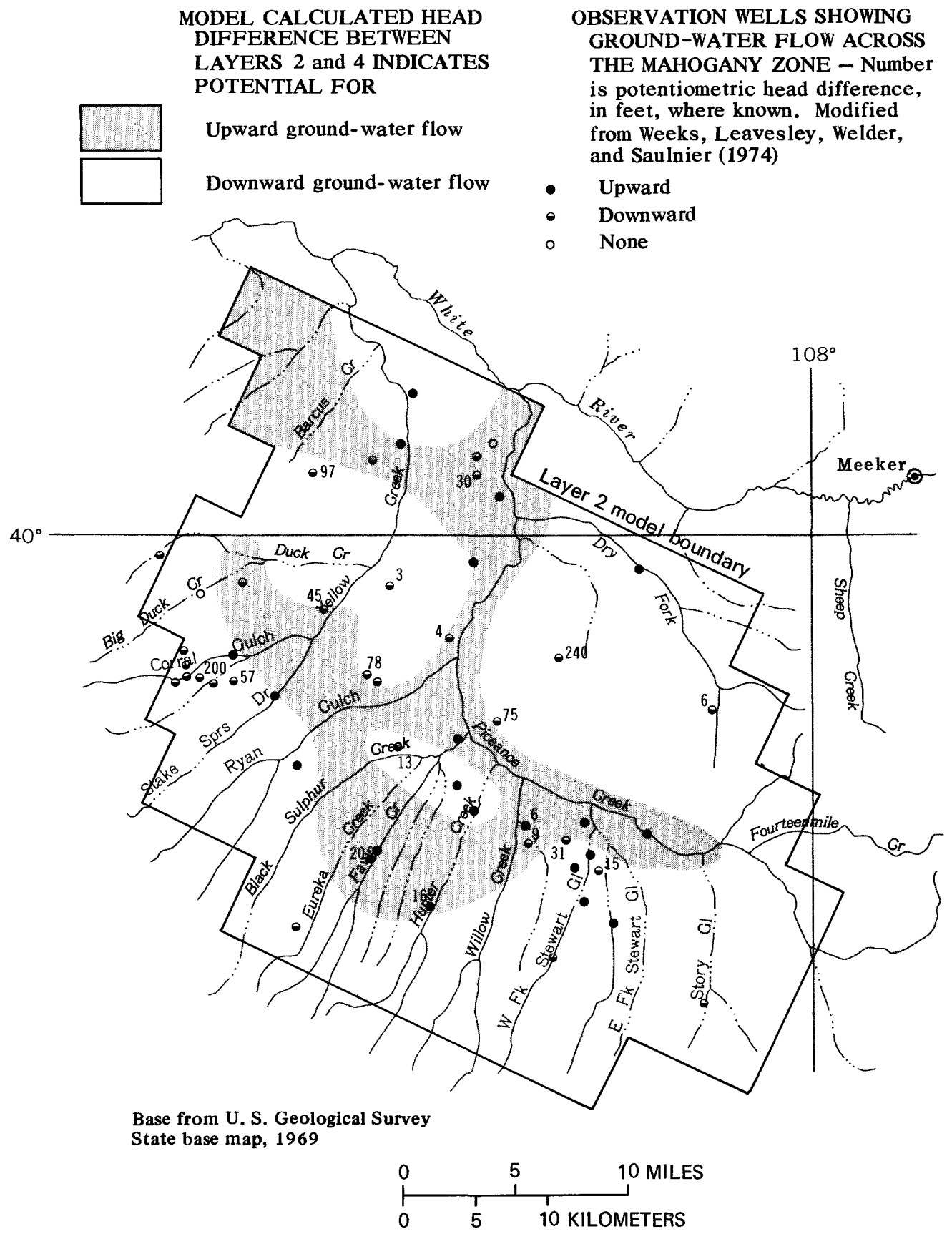

Figure 20.-Difference in potentiometric heads between the upper and lower aquifers.

\section{GEOCHEMICAL SYSTEM}

The concentration of dissolved solids in ground water in the Piceance basin ranges from $400 \mathrm{mg} / \mathrm{L}$ (milligrams per liter) near the margins of the basin to $40,000 \mathrm{mg} / \mathrm{L}$ in the north-central part of the basin. In addition to these lateral changes in quality, large increases in dissolved-solids concentrations also occur with depth in the aquifers. These spatial dif- ferences in concentration are due to changes in water quality along the ground-water flow paths between the points of recharge and the points of discharge. These changes include an increase in dissolved-sohds concentration, and a change in water type from a mixed cation bicarbonate water to a sodium bicarbonate water, oxidation and reduction of sulfur species, and relatively large increases in certain trace 
constituents such as strontium and fluoride. The changes reflect the geochemical environment through which the ground water flows. The magnitude of the changes is affected by the type and concentration of soluble minerals present in the aquifers, the type of clay minerals and amount of organic material present in the aquifers, and the flow path the water follows through the aquifers.

In the highland recharge areas, both sandstones and siltstones of the Uinta Formation and marlstones of the Parachute Creek Member crop out. The soil cover is relatively thin in these areas and snowmelt often infiltrates directly into weathered bedrock before moving down into unweathered bedrock. The infiltrating water carries dissolved atmospheric gases and soluble minerals from the weathered and unweathered surfaces into the upper aquifer. Dissolvedsolids concentrations in the recharge have not been directly measured but are indicated by the chemical quality of water in springs and shallow wells in the upper aquifer. These data indicate that the dissolvedsolids concentrations in the recharge may range from 450 to $800 \mathrm{mg} / \mathrm{L}$, as shown in figure 21. Dissolved carbon dioxide in the form of carbonic acid increases the solubility of the carbonate cements present in the sandstones and the carbonate minerals present in the marlstones. As a result, water samples from springs and surface water in the recharge areas indicate that the ground water varies from a calcium magnesium bicarbonate type to a mixed cation bicarbonate type. Although ground water in the recharge areas is generally in an oxidized state, reducing conditions exist at depth as indicated by the presence of hydrogen sulfide gas in water from springs from deep sources and wells producing water from the upper part of the Parachute Creek Member.

As the ground water in the upper aquifer flows away from the recharge areas, dissolved-solids concentrations increase and the water changes to a sodium bicarbonate type. Large dissolved-solidsconcentration increases occur in the Uinta Formation (layer 1) where concentrations are two to three times as great as in the recharging water, and near the base of the upper part of the Parachute Creek Member (layer 2) where concentrations are 10 or more times as great as in the recharging water. The principal source of this increase appears to be the upward flow of water with large dissolved-solids concentrations from the lower aquifer into the upper aquifer. Upward flow probably accounts for the larger dissolved-solids concentrations near tract $C-b$ and in the north-central discharge areas of the basin (figs. 20 and 24).
Increases in the dissolved-solids concentrations in the lower aquifer probably occur in three ways. First, the dissolved solids increase by dissolution of the host marlstones as water moves through the aquifer. Second, permeable zones produced by fracturing and dissolution of saline minerals near the basin margins laterally abut impermeable sections of the saline zone toward the central part of the basin. The configuration of the edges of the saline zone is highly irregular, resulting in local restrictions to horizontal and vertical flow. This restriction to flow appears to create zones of almost stagnant ground water that slowly dissolves saline minerals from the host rock. Third, water moving through fractures and solution openings in the lower part of the Parachute Creek Member can come in contact with sodium chloride and sodium bicarbonate salts in the aquifer. These soluble minerals dissolve to produce water with dissolved-solids concentrations in excess of $30,000 \mathrm{mg} / \mathrm{L}$. Over geologic time, these processes of dissolution have produced the leached zone.

Saulnier (1978) found that the dissolution is presently most active along the edges of the main body of the saline zone. Further, dissolution in the saline zone is aided by major fractures that penetrate this section and allow circulating ground water to contact the soluble salts. This phenomenon is well displayed in a west-northwest-trending zone of fracturing along the northern margin of the basin (fig. 22). Here fractures allow saline water to move from the lower to the upper aquifer, thereby increasing the dissolved-solids concentrations in the upper aquifer. This fracture-associated dissolution is reponsible for the saline springs in Alkali Flat adjacent to the lower reach of Piceance Creek and Stinking Spring along the lower reach of Yellow Creek. An analogous situation is the probable cause of the saline water pumped from wells that have been drilled through and left open to the saline zone. Saline water moving up the well bores locally contaminates water in the upper aquifer and in the alluvium. In the past, this local contamination has given an erroneous indication of the extent of saline water in the upper aquifer (Welder and Saulnier, 1978, p. 14).

\section{CHEMICAL REACTIONS}

The principal chemical reactions observed in the Piceance basin are dissolution, precipitation, ion exchange, and oxidation reduction. These reactions primarily are responsible for the chemical composition of the ground water in the basin. The reactions are best described in reference to position in the ground-water flow system. 


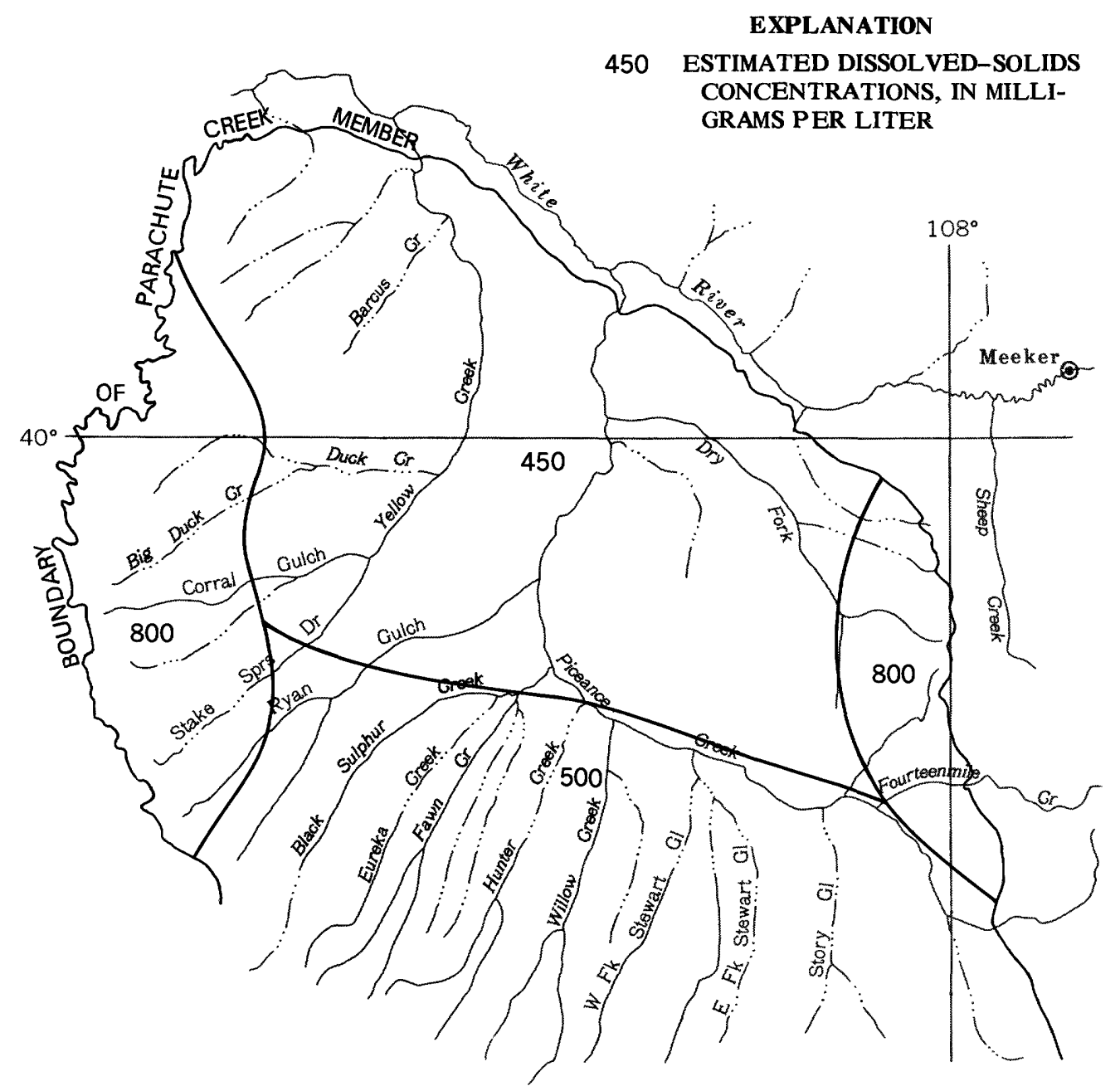

Base from U. S. Geological Survey State base map, 1969

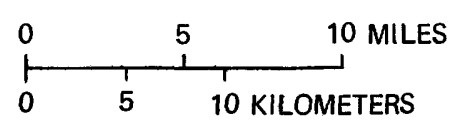

FIGURE 21.-Estimated dissolved-solids concentrations in water recharging the aquifer system.

\section{DISSOLUTION}

Various dissolution reactions occur throughout the basin but specific reactions predominate at different points along the ground-water flow paths. Mineralogic analyses of samples of oil shale from the Green River Formation indicate that about 43 percent of the marlstone is composed of calcite and dolomite (Yen and Chulingarian, 1976). In the Uinta Formation, calcite and dolomite are present as cements in the sandstones and siltstones of the unit. Although these minerals do not dissolve rapidly, the chemical composition of ground water in recharge areas where marlstones are exposed indicates calcite and dolomite are going into solution. Calcium concentrations usually range from 50 to $100 \mathrm{mg} / \mathrm{L}$ and are almost double the magnesium concentrations.

Farther down the ground-water flow path (toward the center of the basin), other dissolution reactions predominate. These reactions involve the evaporative salts, nahcolite and halite, found in the saline zone. The minerals are so soluble that they can be detected during drilling by measuring the specific conductance of water produced during drilling and comparing these data to core samples. Cores containing the salts are often of nonuniform diameter due to the differing rates of dissolution of adjacent segments of the core. Because of the small permeability of this zone (Dale and Weeks, 1978), the minerals can be dissolved only when fractures, wells, or 


\section{EXPLANATION}
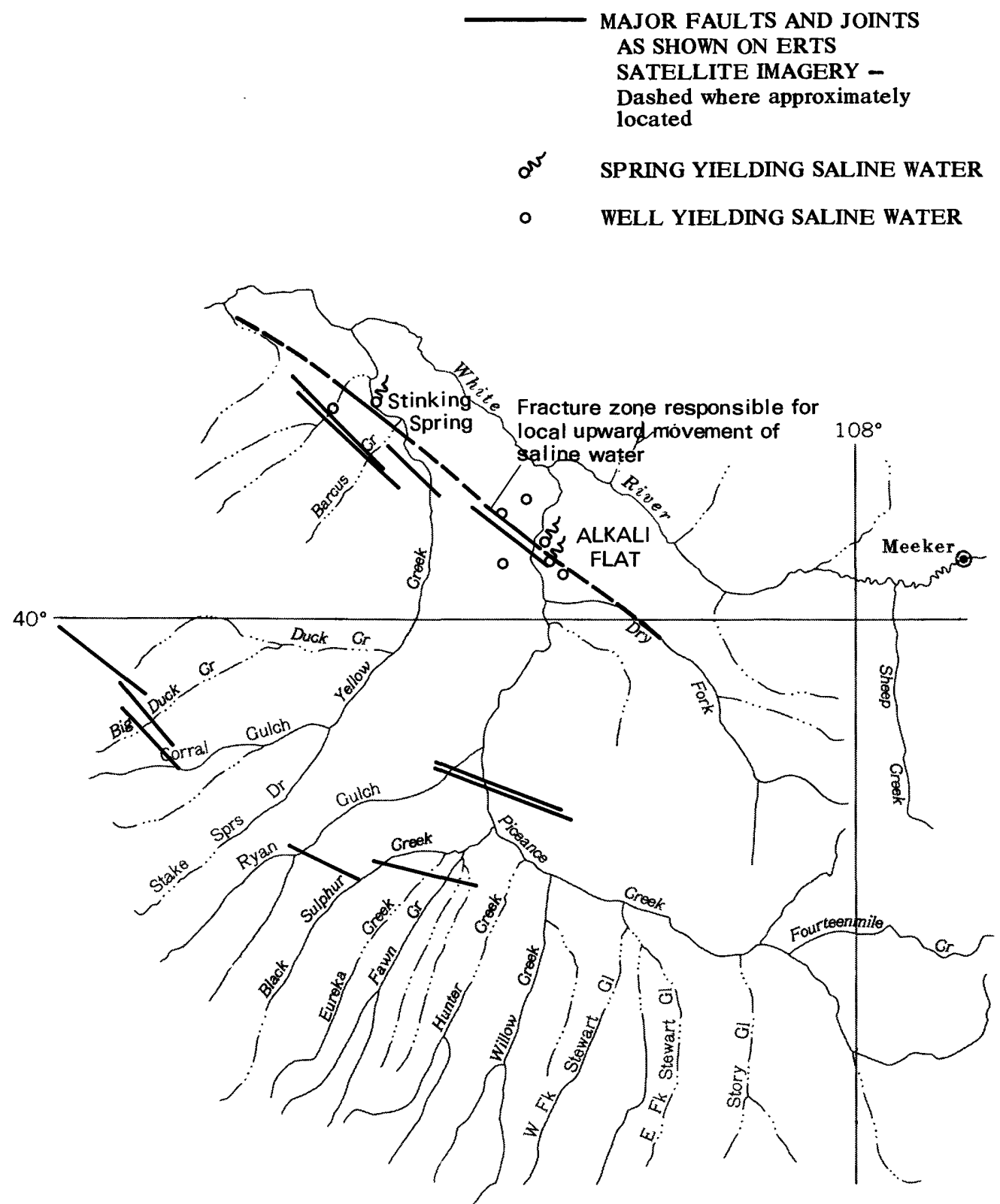

Base from U. S. Geological Survey State base map, 1969

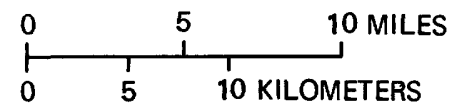

FIGURE 22.-Major faults and joints in the northern part of the Piceance basin (modified from Saulnier, 1978).

adjacent dissolution have exposed the minerals to water. Welder and Saulnier (1978) and Dale and Weeks (1978) report that water from the leached zone in the central part of the basin, where the saline zone is thickest, has a specific conductance that ranges from 1,100 to $1,600 \mu \mathrm{mho} / \mathrm{cm}$ (micromhos per centimeter at $25^{\circ} \mathrm{C}$ ). These relatively small values of specific conductance indicate that only limited dissolution is occurring at the top of the present saline zone. However, the specific conductance of water from wells near the perimeter of the saline zone indicates that large-scale dissolution occurs near the northern margin of the basin and along the edges of the saline zone. Dissolution of these sodium 
salts is a contributing factor in the change of water from a mixed cation bicarbonate type water to a sodium bicarbonate type water. Other factors affecting this change in water type are calcite precipitation and ion exchange, as explained in the following sections.

\section{PRECIPITATION}

Examination of drill cores and unweathered outcrops reveals calcite deposits in fractures and vugs in the Parachute Creek Member. A fault zone in Ryan Gulch contains a 2- to 5-ft wide filling of laminated and crystalline calcite. Springs in the northern part of the basin sometimes issue from travertine mounds, and seeps on cliff faces may flow down "drapings" of calcite and travertine. These occurrences are indirect evidence that calcite is at or near saturation in most ground water in Piceance basin even though maximum calcium concentrations are about $100 \mathrm{mg} / \mathrm{L}$ and may be as small as $10 \mathrm{mg} / \mathrm{L}$ in water from the Parachute Creek Member.

A computer program entitled WATEQ (Truesdell and Jones, 1974) was used to analyze water-quality data for the different aquifer units in the basin to determine the stability of various mineral phases in the ground-water environment. The calculations showed that calcite is at or near saturation in the majority of samples and in nearly all samples collected away from the recharge areas. The precipitation of calcite is probably determined by the generalized reaction:

$$
2 \mathrm{HCO}_{3}{ }^{-}+\mathrm{Ca}^{2+} \rightarrow \mathrm{CaCO}_{3} \mathrm{l}+\mathrm{H}_{2} \mathrm{CO}_{3} .
$$

In Piceance basin, the driving mechanism for such a reaction is the bicarbonate concentrations (usually greater than $300 \mathrm{mg} / \mathrm{L}$ ) in the water. The bicarbonate is supplied by dissolution of carbonate minerals and nahcolite, by the sulfate-reduction reaction discussed below, and possibly by silicate hydrolysis.

Other minerals that have been observed to be precipitated secondarily are pyrite, $\mathrm{FeS}_{2}$, and neighborite, $\mathrm{NaMgF}_{3}$. Pyrite is commonly found lining vugs, filling fractures, and replacing fossil remains in rocks from the Parachute Creek Member, especially below the Mahogany zone. Hydrogen sulfide gas often is detected in wells penetrating the Parachute Creek Member, indicating that reducing conditions are present. At the levels of $\mathrm{pH}$ (7.to 8.8) generally measured in the Piceance basin, pyrite is stable in reduced waters. Pyrite also is found as a primary precipitate in the marlstones, indicating that the secondary minerals may represent recycled pyrite produced by past changes in alkalinity and formation temperature.
Neighborite is a rare mineral and was found only in a few samples from the northern part of the basin. The mineral consists of soft, yellow to white, translucent crystals found in vugs in the Parachute Creek Member. Very little is known about the stability of neighborite, but water in the northern parts of Piceance basin locally contains relatively large concentrations of sodium and fluoride. Plots of water types and ionic ratios calculated for this part of the basin indicate a slight enrichment in magnesium due to calcite precipitation. Larger fluoride concentrations may combine with magnesium to form the ion pair, $\mathrm{MgF}_{3}$, prior to neighborite precipitation.

\section{ION EXCHANGE}

Although the changing of water from a mixed cation bicarbonate type in the recharge areas to a sodium bicarbonate type in the central discharge parts of the basin occurs in both the upper and lower aquifers, the change is more pronounced and occurs in shorter lateral and vertical distances in the Parachute Creek Member. For example, water from a spring issuing from the upper aquifer along upper Black Sulfur Creek has a calcium concentration of 61 $\mathrm{mg} / \mathrm{L}$ and a sodium concentration of $45 \mathrm{mg} / \mathrm{L}$. A sample collected from the lower aquifer at Ryan Ridge in the central part of the basin has a calcium concentration of $4.2 \mathrm{mg} / \mathrm{L}$ and a sodium concentration of $550 \mathrm{mg} / \mathrm{L}$. Dissolution of nahcolite is a significant factor in this change in ionic proportions in areas where brines exist, but in other areas and in the Uinta Formation, another mechanism must account for this change in ionic proportions.

The dolomitic marlstones of the Parachute Creek Member contain significant amounts of clay minerals. Dyni (1976) determined that smectite, illite, chlorite, and kaolinite occur in these rocks and that a progression of clay types occurs from the basin margins to the basin center. Illite is the most common clay mineral in the Piceance basin, especially away from the saline-mineral depocenter. Ground water near the margins of the basin may have calcium concentrations of about $100 \mathrm{mg} / \mathrm{L}$ as the result of dissolution of the dolomitic marlstones. If ion exchange were taking place according to the following reaction ( $X$ indicates an exchange site):

$$
\mathrm{Ca}^{2+}+\mathrm{Na}_{2} \mathrm{X} \rightarrow \mathrm{CaX}+2 \mathrm{Na}^{+},
$$

the calcium would be removed from solution and sodium would become the dominant cation in solution. Although the calcium concentration is not ex- 
cessive, preliminary geochemical model studies indicate that ion exchange may be actively altering the water composition in the central part of the basin.

Another ion exchange mechanism involving dolomite could potentially contribute to the observed magnesium enrichment according to the following generalized reactions ( $X$ indicates an exchange site):

$$
\begin{gathered}
\mathrm{CaMg}\left(\mathrm{CO}_{3}\right)_{2}+\mathrm{Ca} X \rightarrow \mathrm{Mg} X+2 \mathrm{CaCO}_{3}, \\
\mathrm{Mg} X+2 \mathrm{Na}^{+} \rightarrow \mathrm{Na}_{2} X+\mathrm{Mg}^{2+} .
\end{gathered}
$$

This series of reactions could lead to the observed precipitation of low magnesium calcite (Desborough and others, 1974) and relative magnesium enrichment in the water. Sodium concentrations in the water could remain relatively large due to nahcolite dissolution and the calcium-sodium exchange illustrated by reaction 2 .

\section{OXIDATION}

Sulfur is present in ground water in Piceance basin as both oxidized and reduced species. Sulfur in the Uinta Formation is present as the oxidized sulphate ion in concentrations exceeding $500 \mathrm{mg} / \mathrm{L}$. Oxidizing conditions exist in the Uinta Formation due to the availability of oxidized water, which occurs as precipitation recharge. In areas of upward water movement, sulfide species that migrate upward into the Uinta Formation from underlying formations are oxidized to sulfate. In other areas where upward movement of sulfur is not possible, the source of the sulfate in the Uinta Formation is unknown. Gypsum has been recorded only in discharge areas in the Uinta Formation, not in recharge areas or near the water table. In the upper parts of the Willow Creek drainage basin, springs bring water containing hydrogen sulfide gas to the surface from below the Uinta Formation. In this part of the recharge area, such upward leakage along fractures may provide the source of sulfate for the Uinta Formation.

In the Parachute Creek Member, primary and secondary pyrite minerals in the organic-rich marlstones probably provide a sulfur source when exposed to oxidized water in the recharge areas.

\section{REDUCTION}

Water from the organic-rich marlstones of the Parachute Creek Member often contains hydrogen sulfide gas and smaller sulfate concentrations than found in the Uinta Formation. Sulfate concentrations less than $10 \mathrm{mg} / \mathrm{L}$ are common in samples from the lower aquifer. During the drilling of 24 test holes in 197576 , hydrogen sulfide gas commonly was released as the drill penetrated the Parachute Creek Member.

The source of sulfur in the Parachute Creek Member is not certain but the large amounts of organic material present in this unit probably help to maintain a reducing condition throughout much of $\mathrm{Pi}$ ceance basin. The most probable mechanism for sulfide production is through the generalized reaction:

$$
\begin{gathered}
\text { organic material }+\mathrm{SO}_{4}{ }^{2-}- \\
\mathrm{H}_{2} \mathrm{~S}+\text { carbonate species. }
\end{gathered}
$$

Whether biogenic processes are involved in the reduction of sulfate is not clear, but the coincidence of aqueous sulfide species and organic material in the bedrock occurs throughout the basin. This reaction also would act as another contributor to the large concentrations of bicarbonate found in water from this stratigraphic unit.

Pyrite is commonly found in small quantities as a primary and secondary mineral in the Parachute Creek Member (Desborough and Pitman, 1974). This mineral is slightly soluble in warm water and may contribute small amounts of hydrogen sulfide to the water through the following reaction in a reducing environment:

$$
\mathrm{FeS}_{2}+4 \mathrm{H}^{+}+2 e^{-} \rightarrow 2 \mathrm{H}_{2} \mathrm{~S}+\mathrm{Fe}^{2+} .
$$

The $\mathrm{Fe}^{2+}$ ion that would result from reaction in equation 6 may be reprecipitated as the black precipitate often observed during the pumping of wells producing water from the Parachute Creek Member. The $\mathrm{Fe}^{2+}$ ion probably combines with the $\mathrm{HS}^{-}$to precipitate $\mathrm{FeS}$, which is unstable in the oxidizing environment that occurs when the water reaches the surface. This instability causes the precipitate to oxidize in the presence of air to form an iron oxide. Iron oxide coatings are commonly found on rocks that are exposed to the "black water" discharged from wells tapping the Parachute Creek Member.

Secondary pyrite is formed where the dissolved iron, which went into solution in the recharge areas, precipitates out of solution in the discharge areas. Drill cores from the Naval Oil Shale Reserve, immediately to the south of the study area, have extensive pyrite coatings in vugs and on fractures. These secondary pyrite minerals occur where ground water is close to a discharge area.

The product of the principal chemical reactions is a sodium bicarbonate water with oxidized sulfur species 
in the Uinta Formation and reduced sulfur species in the Parachute Creek Member. Carbonate species and, therefore, total carbon dioxide in the sytem are produced by atmospheric introduction via recharge, reduction of sulfur species, and dissolution of the carbonate minerals, calcite, dolomite, and nahcolite. Carbonate species are removed from the system in the northern part of the basin by calcite precipitation. Large sodium concentrations are produced by ion exchange and nahcolite and halite dissolution.

\section{DISTRIBUTION OF TRACE CONSTITUENTS}

Certain trace constituents occur in ground water in the basin in larger than normal concentrations. The relative concentrations of these constituents can be used as an aid in identifying the source of the water in springs and wells. Desborough, Pitman, and Huffman (1974) reported on the mineral residence of many of the trace constituents, and Dyni (1976) speculated that smectites and illites served as traps for trace constituents soon after the lake sediments were deposited. Other sources of trace constituents are in primary sulfide, halide, carbonate, and silicate minerals that occur in the basin sediments. The following data on the occurrence and distribution of trace constituents in ground water in the Piceance basin is excerpted from Saulnier (1978).

Trace constituents that were analyzed for but found in less than significant concentrations were beryllium, copper, cadmium, lead, mercury, manganese, molybdenum, selenium, and zinc. Trace constituents found in significant concentrations to warrant further discussion were arsenic, barium, boron, fluoride, iron, lithium, and strontium.

ARSENIC

Concentrations of dissolved arsenic in ground water in Piceance basin generally do not exceed $50 \mu \mathrm{g} / \mathrm{L}$ (micrograms per liter). However, concentrations of dissolved arsenic between 10 and $50 \mu \mathrm{g} / \mathrm{L}$ are common in water from wells tapping the Parachute Creek Member in the area between Piceance Creek and Dry Fork. Arsenic concentrations of 80 and 95 $\mu \mathrm{g} / \mathrm{L}$.were found in water from two wells located in this area. The mineral residence of arsenic is probably authigenic sulfides in the Parachute Creek Member (Desborough and others, 1974).

\section{BARIUM}

Dissolved-barium concentrations greater than 500 $\mu \mathrm{g} / \mathrm{L}$ occurred in water from about one-third of the sampled wells completed in the lower aquifer. The largest concentrations occurred in the brines found in the northern part of the basin. Barium concentrations generally are less than $500 \mu \mathrm{g} / \mathrm{L}$ in the upper aquifer. Hem (1970) suggests that barium concentrations generally are controlled by the solubility of barite $\left(\mathrm{BaSO}_{4}\right)$. The occurrence of barite as a secondary mineral in the northern part of Piceance basin has been reported (G. A. Desborough, written commun., 1975). Calculations using the WATEQ computer program indicate that the brines in the basin are slightly saturated with respect to barite and are saturated with respect to witherite $\left(\mathrm{BaCO}_{3}\right)$, which also occurs in the area (Milton, 1971). Barium can possibly be complexed with chloride in reduced waters (Holland, 1967), a distinct possibility in the high chloride, reducing waters of the north-central Piceance basin. Upon entering oxidized waters, the relatively insoluble barite would then precipitate as a secondary mineral, the mode of occurrence observed for barite in this study (Plummer, 1971).

\section{BORON}

Concentrations of boron greater than $5,000 \mu \mathrm{g} / \mathrm{L}$ are common in water samples from the lower aquifer and less common in the upper aquifer. Concentrations of this magnitude occur in water throughout the basin but are most common in the northern part of the basin where the brines occur.

Boron is commonly concentrated in evaporites, but no borate minerals have been reported in the Piceance basin. Shepard and Gude (1973) found that boron can occur in potassium feldspars of saline, alkaline, lacustrine deposits. Boron has not been identified in the feldspars of the Piceance basin, but searlsite $\left(\mathrm{Na}_{3} \mathrm{Si}_{2} \mathrm{O}_{6} \cdot \mathrm{H}_{2} \mathrm{O}\right)$, reedmergnerite $\left(\mathrm{NaBSi}_{3} \mathrm{O}_{8}\right)$, garrelsite $\left[(\mathrm{Ba}, \mathrm{Ca}, \mathrm{Mg}) \mathrm{B}_{2} \mathrm{SiO}_{6}(\mathrm{OH})_{3}\right]$, and leucosphenite $\left(\mathrm{CaBaN}_{3} \mathrm{BTi}_{3} \mathrm{Si}_{9} \mathrm{O}_{29}\right)$ have been reported in the Green River Formation (Milton, 1971). Little is known of the solubility of these minerals. As a result, the mineral source of the boron in solution in the Piceance basin is unknown at present.

\section{FLUORIDE}

The distribution of dissolved fluoride in the upper and lower aquifers can be described in relation to the abundance of dissolved calcium as well as the presence of fluoride minerals. The amount of fluoride ion theoretically in solution at equilibrium can be determined by the solubility product $\left(K_{\mathrm{ap}}\right)$ of fluorite $\left(\mathrm{CaF}_{2}\right)$ :

$$
K_{\mathrm{sp}}=\left(\mathrm{Ca}^{2+}\right)\left(\mathrm{F}^{-}\right)^{2} .
$$


Because the fluoride activity is squared, small calcium concentrations would allow large fluoride concentrations to be present in the water. The equilibrium concentration of dissolved calcium fluoride is 15 $\mathrm{mg} / \mathrm{L}$ at $18^{\circ} \mathrm{C}$. The average concentrations are 38 $\mathrm{mg} / \mathrm{L}$ for calcium and $1.1 \mathrm{mg} / \mathrm{L}$ for fluoride in water from the Uinta Formation, $18 \mathrm{mg} / \mathrm{L}$ for calcium and $7.1 \mathrm{mg} / \mathrm{L}$ for fluoride in water from the upper part of the Parachute Creek Member, and $10 \mathrm{mg} / \mathrm{L}$ for calcium and $22 \mathrm{mg} / \mathrm{L}$ for fluoride in water from the lower part of the Parachute Creek Member. Larger concentrations of calcium in water from the Parachute Creek Member would result in the precipitation of fluorite. The reduction of calcium concentrations due to ion exchange and calcite precipitation are thus important factors in maintaining the observed large concentrations of fluoride.

Authigenic cryolite $\left(\mathrm{Na}_{8} \mathrm{AlF}_{6}\right)$, fluorite $\left(\mathrm{CaF}_{2}\right)$, fluorapatite $\left[\mathrm{Ca}_{5}\left(\mathrm{PO}_{4}\right)_{3} \mathrm{~F}\right]$, and neighborite $\left(\mathrm{NaMgF}_{3}\right)$ are present in the Parachute Creek Member (Charles Milton, written commun., 1974). Calculations using the WATEQ computer program indicate that the water is undersaturated with respect to both fluorite and cryolite; thus, these minerals probably are dissolving rather than precipitating. As a result, the large proportion of fluoride in cryolite could add significantly to the dissolved-fluoride concentrations found in the ground water. Little is known about the kinetics of dissolution of these minerals in the presence of water containing relatively small concentrations of calcium and relatively large concentrations of sodium.

The original source of the fluoride is uncertain. The fluoride may have been added to Lake Uintah by hot springs or volcanic ash. Devitrified tuffaceous lenses are common in the Green River Formation. Evaporation from the lake could have concentrated the fluoride sufficiently to form authigenic fluoride minerals and allow the inclusion of the fluoride ion in clay minerals. After induration and basin deformation, circulating ground water reversed the process, allowing relatively large concentrations of fluoride to be present in the water. At some time after resolution of the fluoride, neighborite $\left(\mathrm{NaMgF}_{3}\right)$ precipitated in vugs. It appears likely that the formation of $\mathrm{MgF}_{3}^{-}$complexes precedes neighborite precipitation. As in the calcium fluoride example above, the solubility product indicates that relatively small magnesium concentrations would be required to maintain the relatively large fluoride concentrations. In the lower aquifer, the smallest concentrations of dissolved magnesium are found to coincide with the largest concentrations of dissolved fluoride as required by the solubility product calculations.
The absence of significant concentrations of dissolved fluoride in the Uinta Formation is due to the combination of relatively larger calcium concentrations than in the Parachute Creek Member and the absence of a source of fluoride in the sediments or in authigenic minerals. Near some fractures, faults, and improperly constructed wells, water in the alluvial aquifer and the Uinta Formation has unusually high concentrations of fluoride for this formation. These relatively larger concentrations occur in the northern part of the basin where the potentiometric head allows upward movement of water from the Parachute Creek Member.

\section{IRON}

Water with more than $300 \mu \mathrm{g} / \mathrm{L}$ of dissolved iron is common in the upper aquifer. The sandstones and siltstones of the Uinta Formation have ironstone concretions throughout. These concretions probably are the major source for much of the dissolved iron.

The Parachute Creek Member contains variable amounts of authigenic pyrite (Trudell and others, 1970). In the recharge areas and in the warm bicarbonate water found in the lower aquifer where the pH normally ranges from 7.5 to 8.5 , pyrite either can be dissociated to form ferrous ions in solution or the ferrous ion can combine with carbonate to form siderite and ferroan $\left[(\mathrm{Mg}, \mathrm{Fe}), \mathrm{CO}_{3}\right]$. The presence of siderite and ferroan are commonly reported in the Parachute Creek Member (Desborough and others, 1974; Robb and Smith, 1974). Relatively small concentrations of iron occur in water in the Parachute Creek Member, indicating that most dissolved iron may be reprecipitated as carbonate. As noted above, the "black water" produced from many wells in the Parachute Creek Member indicates that some ferrous iron remains in solution and is carried into wells and subsequently precipitated as FeS.

\section{LITHIUM}

Concentrations of dissolved lithium are greater than $100 \mu \mathrm{g} / \mathrm{L}$ in water samples from wells that contain brines. Relatively large concentrations of lithium also are associated with water that has relatively small dissolved-solids concentrations but relatively large concentrations of other trace constituents. The largest concentrations of lithium occur in samples from wells in the central part of the basin. Dissolved lithium concentrations as much as 39 and $42 \mathrm{mg} / \mathrm{L}$ have been reported in water from these wells. Desborough and others (1974) did not find a likely mineral residence for lithium but indicated that fluoride and lithium show a positive correlation 
in water samples from the Piceance basin reported in Ficke, Weeks, and Welder (1974). Relatively large lithium concentrations also are associated with relatively large concentrations of bicarbonate. The lithium may occur in the evaporite minerals of the Parachute Creek Member either as a carbonate or a chloride. In addition, lithium may be, adsorbed on clays. It is possible that in predominantly sodium waters, sodium could exchange for adsorbed lithium in smectites and illites. Because these same waters also have relatively small calcium concentrations and consequently relatively large fluoride concentrations, the result would be a positive lithium-fluoride correlation.

\section{STRONTIUM}

Strontium is a significant trace constituent in the upper aquifer system, especially in the Uinta Formation and its associated marlstone tongues. In samples from springs in drainage basins tributary to Piceance Creek, strontium concentrations increase downgradient in a distance of 10 to $15 \mathrm{mi}$. Thus, minerals containing strontium probably are being dissolved by the circulating ground water. Calculations using the WATEQ computer program indicate the water generally is supersaturated with respect to strontianite $\left(\mathrm{SrCO}_{3}\right)$ but not with respect to celestite $\left(\mathrm{SrSO}_{4}\right)$. However, celestite is rarely reported in mineral analyses in Piceance basin.

The strontianite supersaturation indicates a precipitation reaction that is very slow. Thus, the strontium in solution could be dissolved from carbonates or sulfates in the first few miles of the flow system and remain dissolved in the water, accumulating due to a slow rate on mineral precipitation. The original source of the strontium in the Uinta Formation is unknown, but it is possible that strontium occurs in the carbonate cements or as accessory sulfate in the Uinta Formation.

\section{THE SIMULATED HYDROLOGIC SYSTEM}

Mining of oil shale from tracts $\mathrm{C}-\mathrm{a}$ and $\mathrm{C}-\mathrm{b}$ will require water to be pumped from the mines in order to prevent flooding. The pumping could cause waterlevel declines in the aquifers and reduce the rate of ground-water discharge to streams near the mines. In addition, the pumping could alter the location of ground-water flow paths, thereby producing changes in the chemical quality of the water in the aquifers and in local streams. Spent shale also could become a source of ground-water quality degradation once the mining intervals have been exhausted and the mine retorts containing the spent shale become flooded. Studies by Ward, Margheim, and Lof (1971) and Schmidt-Collerus (1974) indicate that between 1 and 5 percent of the spent shale may be water-soluble saline minerals. On abandoning tract $C-b$, for example, the volume of saline minerals in the spent shale might range from 30 to $\mathbf{1 5 0}$ million tons and could thus have a serious long-term impact on the water quality near the abandoned mine. Mathematical-modeling techniques may be used to evaluate the possible effects of various mine-pumping practices and subsequent mine flooding. Weeks, Leavesley, Welder, and Saulnier (1974) and Sokol (1976) determined some of the possible effects of mine dewatering on the water levels in the upper and lower aquifers in Piceance basin; however, they did not study the water-quality changes that may accompany the mining activities.

\section{MODEL DESCRIPTION}

In order to simulate the possible effects of the mines on ground-water quality, a three-dimensional mathematical model that simulates solute transport through the ground-water system was constructed. The model is based on a finite-difference solution technique developed for the U. S. Geological Survey by INTERCOMP, Ine. (1976). The model simulates confined, density-dependent flow and solute transport with dispersion in nonhomogeneous, anisotropic aquifers with irregular geometry under steady- or transient-flow conditions. The model simulates movement of a conservative solute (dissolved-solids concentrations) with dissolution as the only chemical reaction term. As a result, the complex geochemical system in the basin can only be simulated to the extent that the geochemistry affects the dissolved-solids concentrations in the aquifer. This is not a severe restriction, however, because dissolution of evaporite minerals in the saline zone and dissolution in the unsaturated zone are the predominant chemical reactions occurring in the basin, and these reactions dominate the effects of the other geochemical reactions. The basic equations that describe the ground-water flow and material balance of the solute have pressure and concentration as the primary dependent variables. The independent variables include: (1) Time; (2) aquifer characteristics, such as hydraulic conductivity, aquifer extent and thickness, porosity, compressibility, solubility, and dispersivity; (3) fluid characteristics, such as concentration, density, compressibility, viscosity, and flux rate; and (4) related initial and boundary conditions.

The node network used in the Piceance basin model 
consists of a 9- by 14-cell array for each of the five layers considered in the model. The lateral model boundary for any individual layer may vary from the boundary of an adjacent layer due to the differences in the lateral extent of the layer in each depth interval.

The hydrologic-model parameters are described at each node in the model area. The thickness of each model layer corresponds to the saturated thickness shown in figures $5,7,8,9$, and 11 . The hydraulicconductivity values assigned to the $x, y$, and $z$ components for each model layer are shown in figures 12 to 17 . The porosity, potentiometric-head, groundwater quality, and specific-storage data discussed previously also were used to define the independent variables of the model.

Dissolution was simulated by using the groundwater recharge sources in the model program to supply mass to the aquifer. The rate at which the mass was supplied corresponds to the rate of dissolution.

\section{MODEL CALIBRATION}

In order to assure that the model calculations are correct, a calibration procedure was used to check the model-calculated potentiometric heads and dissolvedsolids concentrations against the corresponding measured values. The present potentiometric heads and dissolved-solids concentrations are representative of the long-term ground-water conditions in the basin because only minimal ground-water development has occurred as of 1977. Because of the lack of transient-flow conditions in the basin, a steady-flow calibration of the model was the only calibration check possible. In this type of calibration, the model is used to simulate the long-term water-level and waterquality conditions that would result from an undisturbed natural environment. These model results are then compared to the measured data as a check of the simulation capability of the model. A disadvantage of this type of calibration is that the specific storage of the aquifers cannot be tested in the model. However, if subsequent model simulations represent long-term equilibrium conditions, the specific storage will not affect the model results.

Model simulations made using different values of dispersivity indicated that the best model results were obtained when the simulated dispersion equaled the numerical dispersion due to space- and timetruncation errors. Subsequent model simulations were made using zero-longitudinal and transverse-dispersivity factors with dispersion due only to truncation error in the backward finite-difference approximation in space and time. This approach appears to be reasonable for two reasons. First, as the node size and scale of a solute-transport model increases, the model results become less sensitive to dispersivity (Robson, 1974). Because of this, similar modelconcentration distributions can be obtained using very different values of model dispersivity. Second, test simulations were made using a centered-in-spaceand-time finite-difference approximation (which produces no numerical dispersion) and the backward-inspace-and-time approximation (which produces numerical dispersion). Comparison of these two simulations indicated that, at the node sizes used in the Piceance basin model, the effects of numerical dispersion would not adversely affect the concentration distribution. The centered-in-space-and-time approximation could not be used in thePiceance basin model due to problems of solution stability inherent in this technique.

The equilibrium potentiometric heads calculated by the model for layers 1 and 5 are compared in figure 23 to the measured potentiometric heads in the upper and lower aquifers (figs. 18 and 19). The best agreement between calculated and measured potentiometric heads occurs in model layer 1 where calculated heads are within $10 \mathrm{ft}$ of measured heads at 77 of the 86 model nodes in this layer. The degree of agreement is due partly to the effect of the stream valleys of Piceance and Yellow Creeks that tend to control the water levels in the upper aquifer near the valleys. The deeper the model layer is below the stream valleys, the less effect the valleys have on the potentiometric head in the layer. As a result, the calculated potentiometric heads in layer 5 are within $10 \mathrm{ft}$ of the measured potentiometric heads at only 39 of the 104 nodes in this layer (fig. 23). The modelcalculated potentiometric-surface maps for layers 2 and 4 are nearly identical to the potentiometricsurface maps based on measured data shown on figures 18 and 19 , indicating that the model is able to produce a reasonable simulation of equilbrium potentiometrichead conditions. This agreement is further indicated by the comparison of measured and calculated potentiometric-head differences across the Mahogany zone shown in figure 20 . In the areas of greatest potentiometric-head difference, away from Piceance Creek and Yellow Creek valleys, the agreement between measured and calculated data is good. There is less agreement near the streams where only slight potentiometric-head differences occur across the Mahogany zone. 


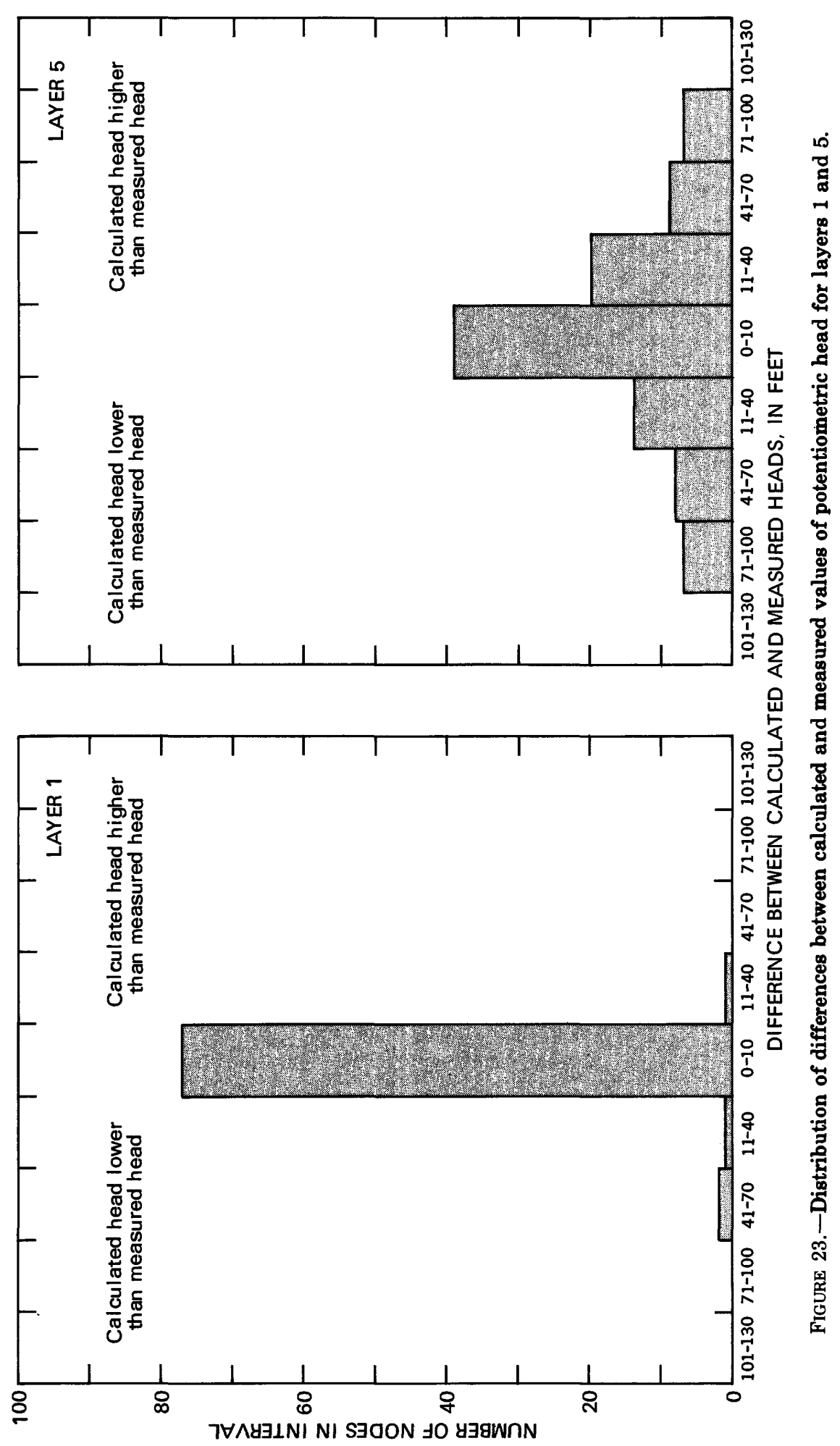


Because the model calculates dissolved-solids concentrations in addition to potentiometric heads, the calibration procedure also compared measured and calculated concentration data. The measured and model-calculated dissolved-solids concentrations for each of the five model layers are shown in figures 24 to 28. Attempts to manually draw lines of equal concentration based on the measured data shown on the left of figures 24 to 28 have met with only limited success. The data points, although fairly numerous, apparently are not adequate to properly define the extent of areas of equal concentration. The reason for this difficulty became apparent when the model results were mapped. As shown on the right side of the figures, the calculated dissolved-solids distribution is multimodal, showing many areas of high and low concentration in the basin. This complex distribution is difficult to define based only on the measured data available. When a comparison is made between the measured and calculated dissolved-solids concentrations, a reasonable degree of agreement is evident. The best agreement between the measured and calculated values occurs in layer 5 . This is significant because the rate of dissolution at the saline zone has a controlling effect on the concentration distribution in layer 5 . Thus, the dissolution rate simulated in the model must be reasonably correct in order for the calculated dissolved-solids concentrations in layer 5 to agree with the measured data.

A third calibration check on the simulation ability of the model involved a comparison of the measured and calculated quantity and chemical quality of water recharging to or discharging from the aquifer system. These data are shown in table 2 with dissolved- solids concentrations expressed in terms of pounds of salt per day.

The estimated-flow data are based on the work of Weeks, Leavesley, Welder, and Saulnier (1974) and represent hydrologic conditions in the basin prior to the Rio Blanco subsurface nuclear detonation which altered the streamflow characteristics in Piceance Creek after April 1973. Estimated salt-load values were computed from water-quality and streamflow records for the Piceance and Yellow Creeks gaging stations near the White River (U. S. Geological Survey, 1961-75). Since the ground-water basin is in equilibrium, the salt load leaving the basin must equal the salt load entering the basin. The total salt load for the recharge terms was, therefore, estimated to be equal to the total salt load for the discharge terms. Aquifer dissolution is the rate of dissolution of soluble minerals in the aquifer and the saline zone. In using the model to calculate the rate of aquifer dissolution, it was necessary to simulate a very small flow rate $\left(0.2 \mathrm{ft}^{3} / \mathrm{s}\right)$, although ground-water flow does not actually originate from aquifer dissolution.

Significant agreement exists between the estimated and calculated flow and salt-load data shown in table 2. The discharge to Yellow Creek shows the greatest difference; however, $3.5 \mathrm{ft}^{3} / \mathrm{s}$ may be a better estimate of the ground-water discharge to the Yellow Creek drainage area than the 4.5 to $5.9 \mathrm{ft}^{3} / \mathrm{s}$ previously estimated. The lower estimate is based on the physical setting of lower Yellow Creek, the surface-water discharge and salt load in the creek, and sensitivity evaluations made using this model.

When the model-calculated ground-water discharge and dissolved-solids concentrations to Piceance

TABLE 2.-Ground-water mass balance

\begin{tabular}{|c|c|c|c|c|}
\hline & \multicolumn{2}{|c|}{ Estimated values } & \multicolumn{2}{|c|}{ Calculated values } \\
\hline & $\begin{array}{c}\text { Flow } \\
\left(\mathrm{ft}^{\mathrm{t}} / \mathrm{g}\right)\end{array}$ & $\begin{array}{c}\text { Salt load } \\
(\mathbf{b} / \mathrm{d})\end{array}$ & $\begin{array}{l}\text { Flow } \\
\left(\mathrm{ft}^{3 / \mathrm{g})}\right.\end{array}$ & $\begin{array}{l}\text { Salt Ioad } \\
\text { (ab/d) }\end{array}$ \\
\hline $\begin{array}{l}\text { Recharge terms: } \\
\text { Precipitation recharge .... } \\
\text { Aquifer dissolution }\end{array}$ & $\begin{array}{c}33.4-36.1 \\
0.0\end{array}$ & $\begin{array}{l}\left({ }^{1}\right) \\
\left({ }^{1}\right)\end{array}$ & $\begin{array}{r}32.4 \\
0.2\end{array}$ & $\begin{array}{l}0.9 \times 10^{5} \\
1.1 \times 10^{5}\end{array}$ \\
\hline Total recharge terms ....... & $33.4-36.1$ & $2.0 \times 10^{5}$ & 32.6 & $2.0 \times 10^{5}$ \\
\hline $\begin{array}{l}\text { Discharge terms: } \\
\text { Piceance Creek } \\
\text { Yellow Creek }\end{array}$ & $\begin{array}{r}27.3-31.6 \\
5.9-4.5\end{array}$ & $\begin{array}{l}1.8 \times 10^{5} \\
0.2 \times 10^{5}\end{array}$ & $\begin{array}{r}29.0 \\
3.5\end{array}$ & $\begin{array}{l}1.8 \times 10^{5} \\
0.2 \times 10^{5}\end{array}$ \\
\hline Total discharge terms & 33.4-36.1 & $2.0 \times 10^{5}$ & 32.5 & $2.0 \times 10^{5}$ \\
\hline
\end{tabular}

${ }^{1}$ No data available. 
THE SIMULATED HYDROLOGIC SYSTEM

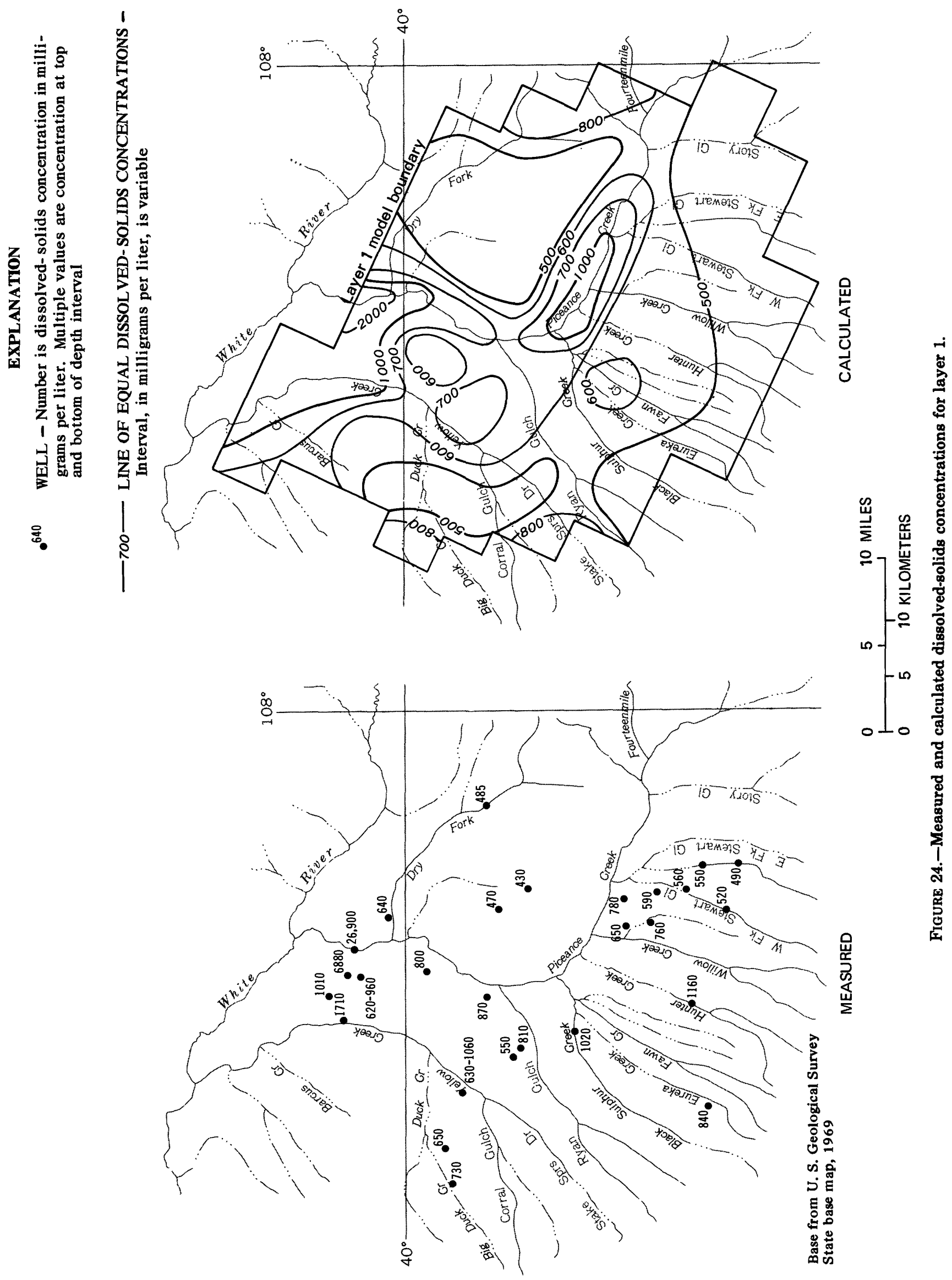



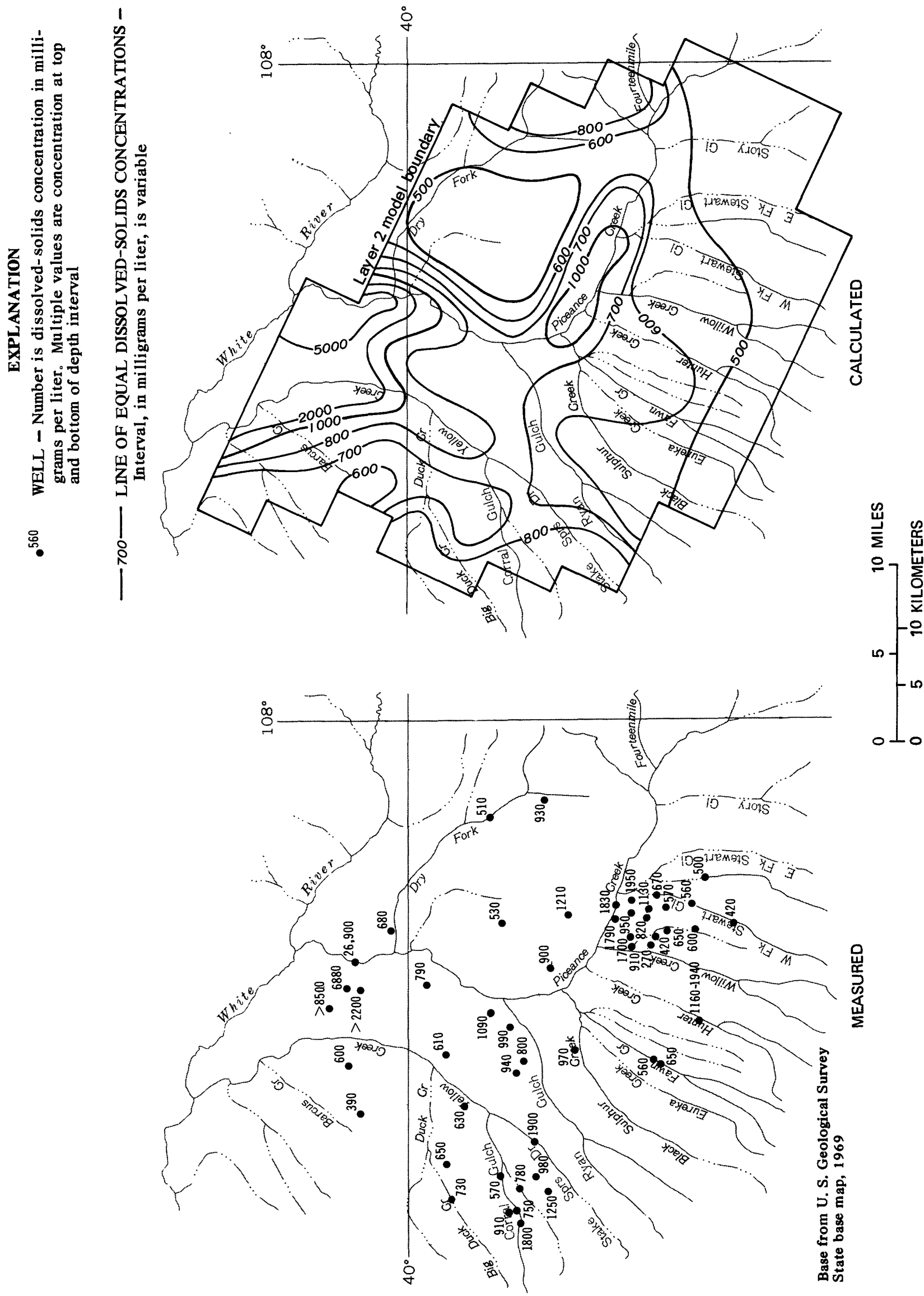
THE SIMULATED HYDROLOGIC SYSTEM

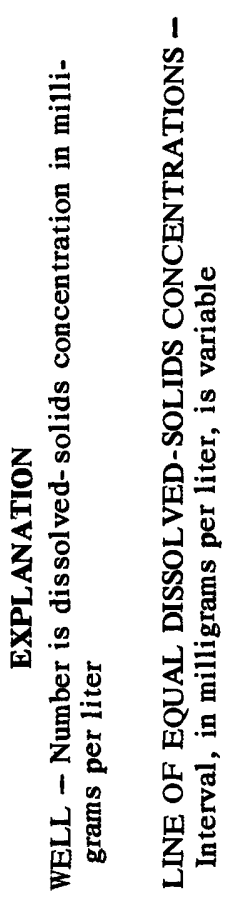

‥
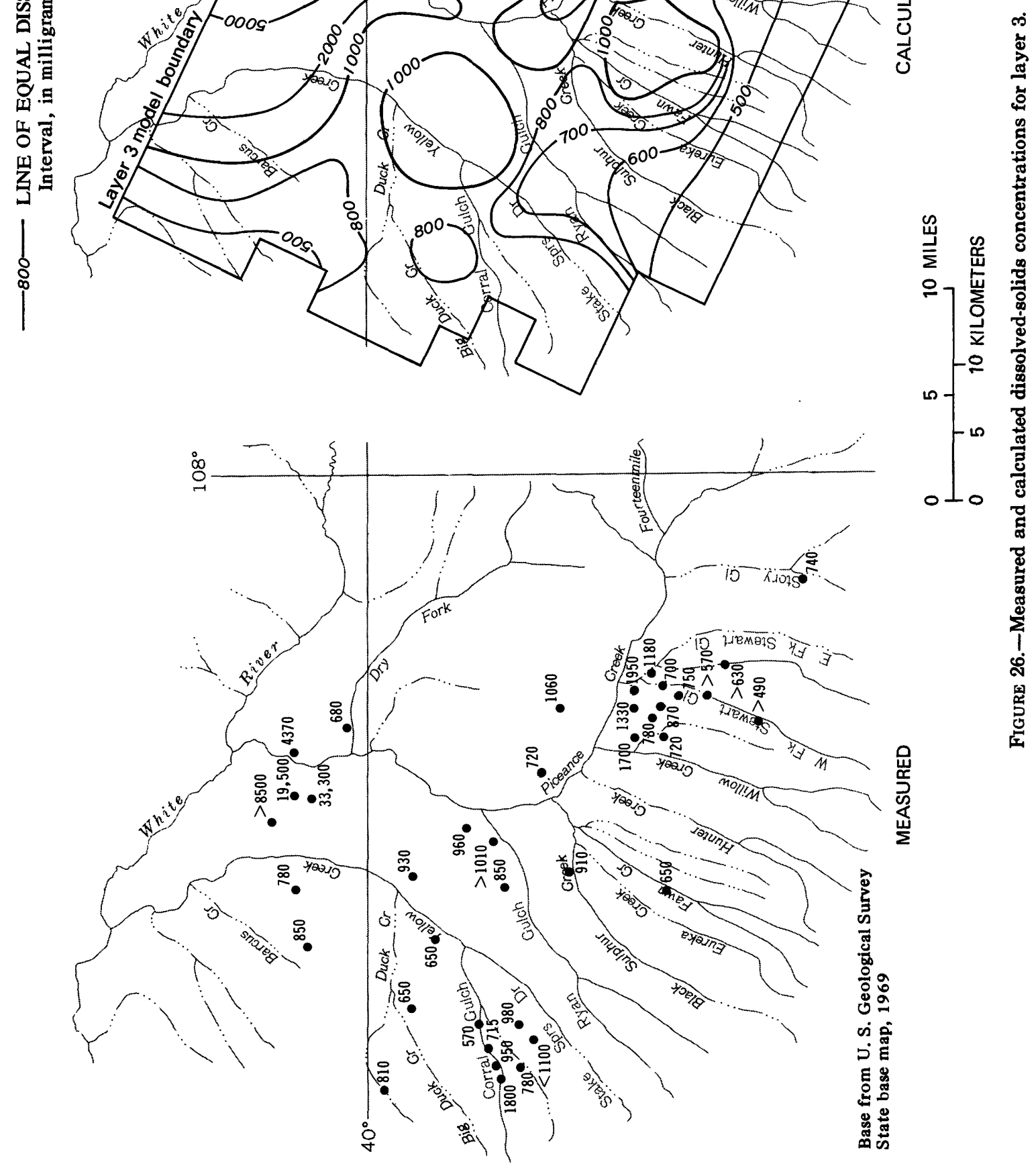

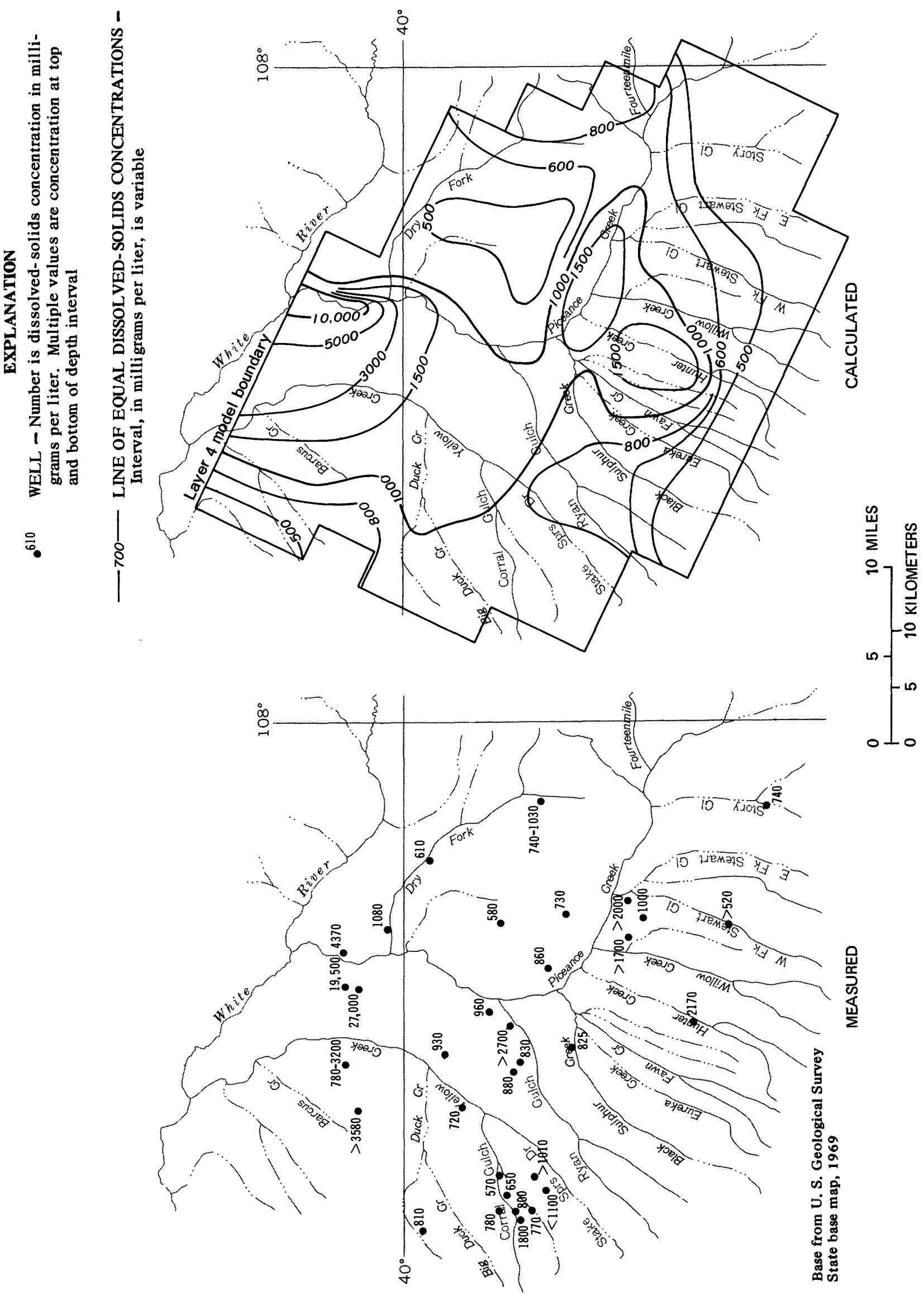


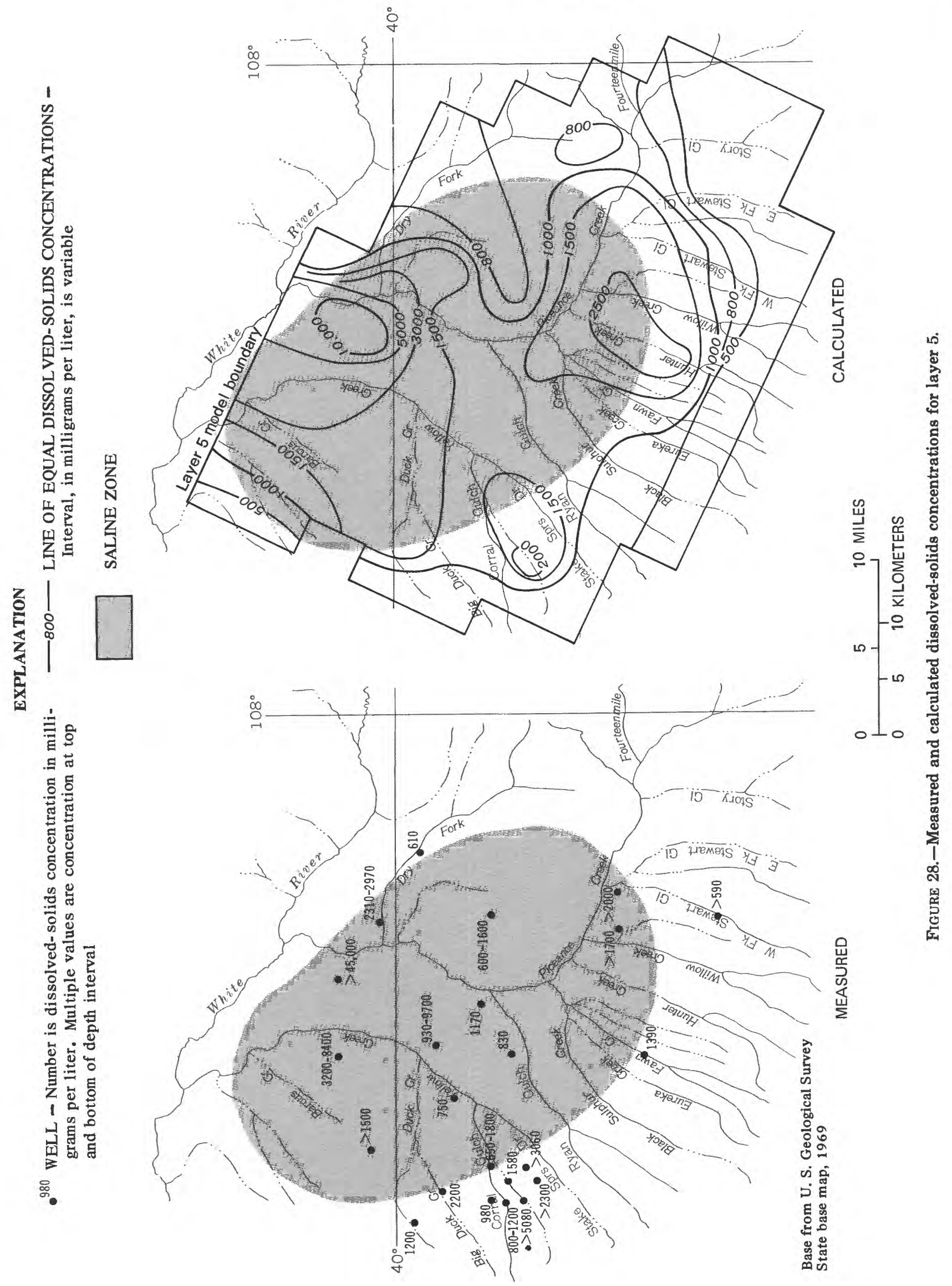


and Yellow Creek valleys are corrected for evapotranspiration losses and surface runoff, the dissolved-solids concentrations of the mean-annual streamflow may be estimated. The model-calculated estimates for these values were $1,600 \mathrm{mg} / \mathrm{L}$ for Piceance Creek and $2,400 \mathrm{mg} / \mathrm{L}$ for Yellow Creek. Using streamflow records for Piceance Creek and Yellow Creek at the near White River gaging stations (U.S. Geological Survey, 1961-75), the dissolved-solids concentrations of mean-annual streamflow in Piceance Creek was calculated to be $1,620 \mathrm{mg} / \mathrm{L}$ and in Yellow Creek to be $2,450 \mathrm{mg} / \mathrm{L}$. The close agreement between the estimates indicates that the model correctly calculates the dissolved-solids concentration in ground-water discharge to streams in the basin as measured at the basin boundary. Based on this model study, about 90 percent of the ground water and dissolved solids in the basin is discharged in Piceance Creek drainage, and the remaining 10 percent is discharged in Yellow Creek drainage.

\section{HYDROLOGIC KNOWLEDGE GAINED THROUGH MODELING}

The successful calibration of the model has demonstrated that the model is a reasonably valid tool for evaluating the hydrogeochemistry of the Piceance basin. Such an evaluation commonly involves model calculations of the effects of various stresses on the aquifers and streams, but of equal importance is the added hydrologic knowledge gained by constructing and calibrating the model.

Different rates and distributions of precipitation recharge were tried during model calibration until a configuration was found that produced a good match between the measured and calculated potentiometric surfaces. The resulting recharge configuration is shown in figure 29 and, in most areas, is similar to the distribution of October to April precipitation in the area (U.S. Weather Bureau, 1960) and the recharge rates and distribution calculated by Weeks, Leavesley, Welder, and Saulnier (1974). The recharge rate in the area between Dry Fork and Piceance Creek is larger than that previously estimated (Weeks and others, 1974), due in part to a lack of potentiometric-head data in this area at the time of the earlier work.

Prior to the construction of this model, few data were available on the rate and distribution of dissolution of the saline minerals occurring in the aquifers or in the saline zone. By using the model to evaluate various dissolution rates, it was possible to determine rates that appear reasonable and produce the proper dissolved-solids concentration in the aquifers. It was found that the areas of greatest dissolution occur (fig. 30) either near the margins of the saline zone or along a northwest-trending fracture system near the northern part of the basin (fig. 22). These findings were reached independently of similar findings discussed previously (see discussion in "Geochemical System section") and support the previous conclusions. These results suggest that the relatively small permeability of the horizontal bedding in the sediments limits rapid dissolution to areas where (1) fracturing allows additional groundwater movement through the soluble minerals, or (2) ground water is able to contact the soluble minerals by lateral movement into the margins of the saline zone.

The rate of dissolution occurring in the aquifers was found to be much less than the dissolution rate at the saline zone (table 3). This is consistent with core-drilling results that commonly show negligible saline-mineral content above the saline zone (Dyni, 1974). Model results indicate that about $1 \times 10^{5} \mathrm{lb} / \mathrm{d}$ of dissolution occurs at the saline zone while about $7 \times 10^{3} \mathrm{lb} / \mathrm{d}$ of dissolution occurs in the aquifers.

TABLE 3.-Mineral-dissolution rates

\begin{tabular}{|c|c|}
\hline $\begin{array}{l}\text { Source of dissolved solids } \\
\text { in ground water }\end{array}$ & $\begin{array}{c}\text { Dissolution rate } \\
\text { (lb/d) }\end{array}$ \\
\hline Saline zone and layer 5 & 100,000 \\
\hline Layer 4 & 4,000 \\
\hline Layer 3 & 300 \\
\hline Layer 2 & 2,000 \\
\hline Layer 1 & 600 \\
\hline Unsaturated zone & 90,000 \\
\hline
\end{tabular}

As precipitation recharge percolates through the unsaturated sediments of the Uinta Formation overlying the aquifer, soluble minerals are dissolved and ultimately carried into the aquifer. This form of dissolution is the second largest source of dissolved solids in the Piceance basin aquifers, totaling about $9 \times 10^{4} \mathrm{lb} / \mathrm{d}$. The distribution of this source is indicated on figure 21 . The areas with recharge concentrations of 450 and $800 \mathrm{mg} / \mathrm{L}$ contribute an average salt load of $240(\mathrm{lb} / \mathrm{d}) / \mathrm{mi}^{2}$ to the aquifers and the area with recharge concentrations of $500 \mathrm{mg} / \mathrm{L}$ contributes an average of $150(\mathrm{lb} / \mathrm{d}) / \mathrm{mi}^{2}$.

The model-calculated ground-water discharge to the streams and alluvial aquifers in Piceance and Yellow Creek valleys is plotted in figure 31 to show 
EXPLANATION

RECHARGE RATE, IN INCHES PER YEAR

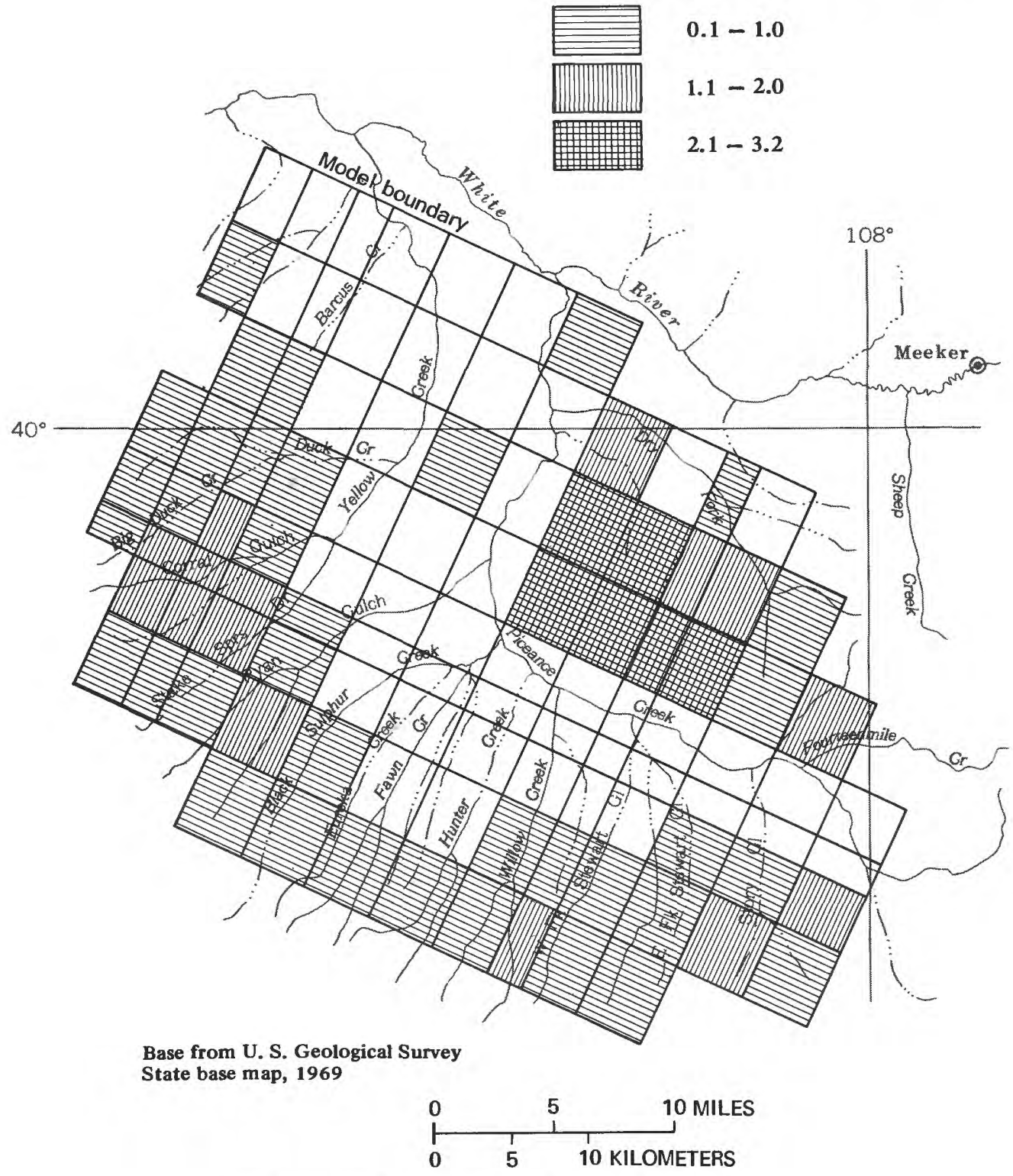

FIGURE 29.-Precipitation recharge distribution.

the cumulative distribution from upstream to downstream reaches of the valleys. The rate of groundwater discharge in the Piceance Creek valley is relatively steady in a reach extending from 4 to $31 \mathrm{mi}$ upstream from the White River. The dissolved-solids distribution, by contrast, shows markedly larger concentrations of dissolved solids in the groundwater discharge in two reaches 0 to $9 \mathrm{mi}$ and 24 to $28 \mathrm{mi}$ upstream from the White River. These two reaches overlie two areas with relatively large rates of salinemineral dissolution in the saline zone (fig. 30). A similar increase in the dissolved-solids concentration of ground-water discharge to Yellow Creek occurs 10 to $14 \mathrm{mi}$ upstream from the White River, and this reach also overlies an area of rapid dissolution in the saline zone. These model results indicate that, if evapotranspiration and underflow in the alluvium can be accounted for, it might be possible to make an 


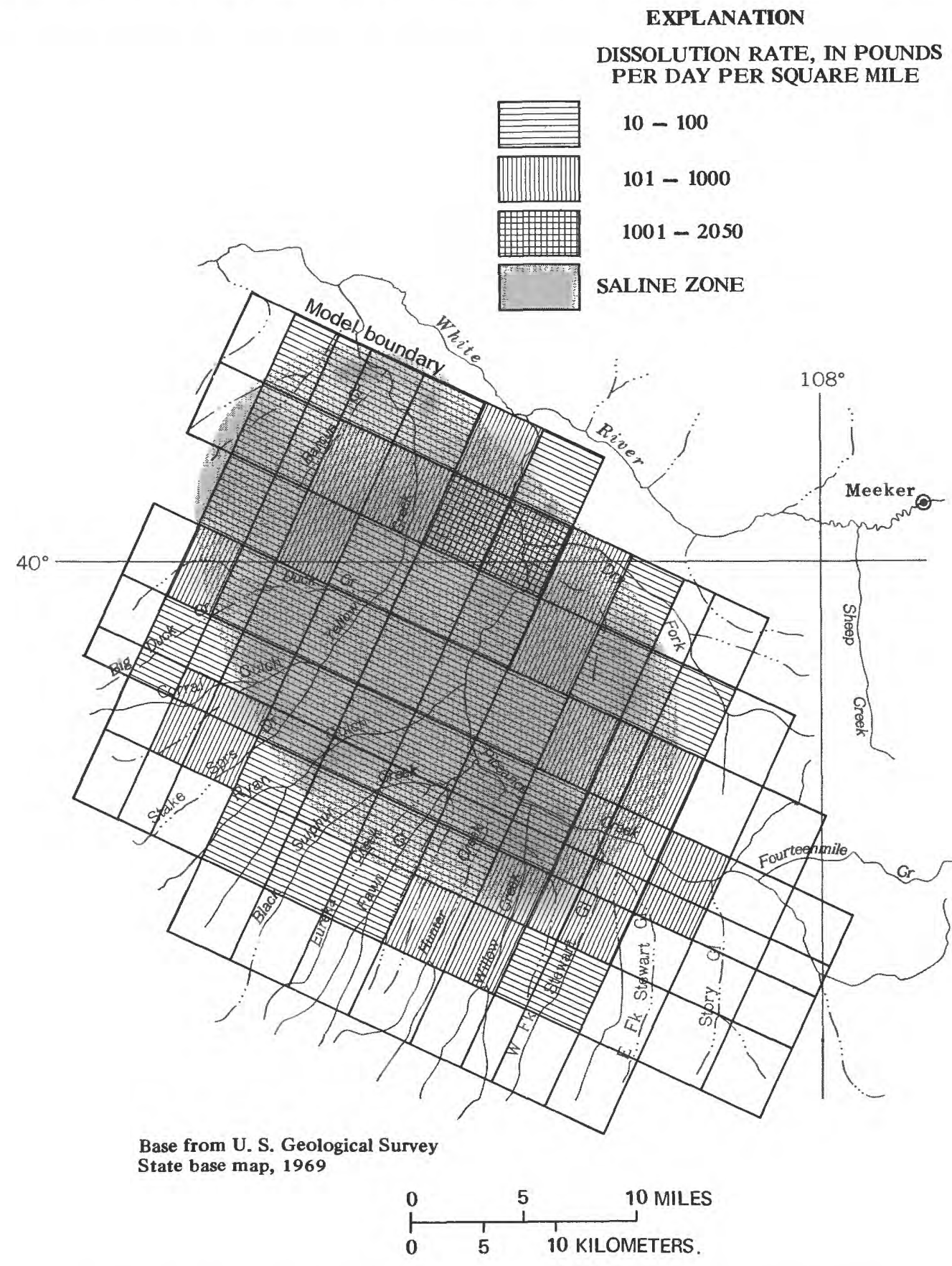

FIGURE 30.-Rate of dissolution of saline minerals at the base of the aquifer system.

onsite determination of the relative rate of salinemineral dissolution in the saline zone simply by monitoring changes in the quality of surface water during relatively low flows along Piceance or Yellow Creeks.

\section{MODEL SIMULATIONS}

The ground-water model developed as part of this investigation is capable of calculating the potentiometric head and dissolved-solids concentrations that result from a given set of ground-water recharge and 

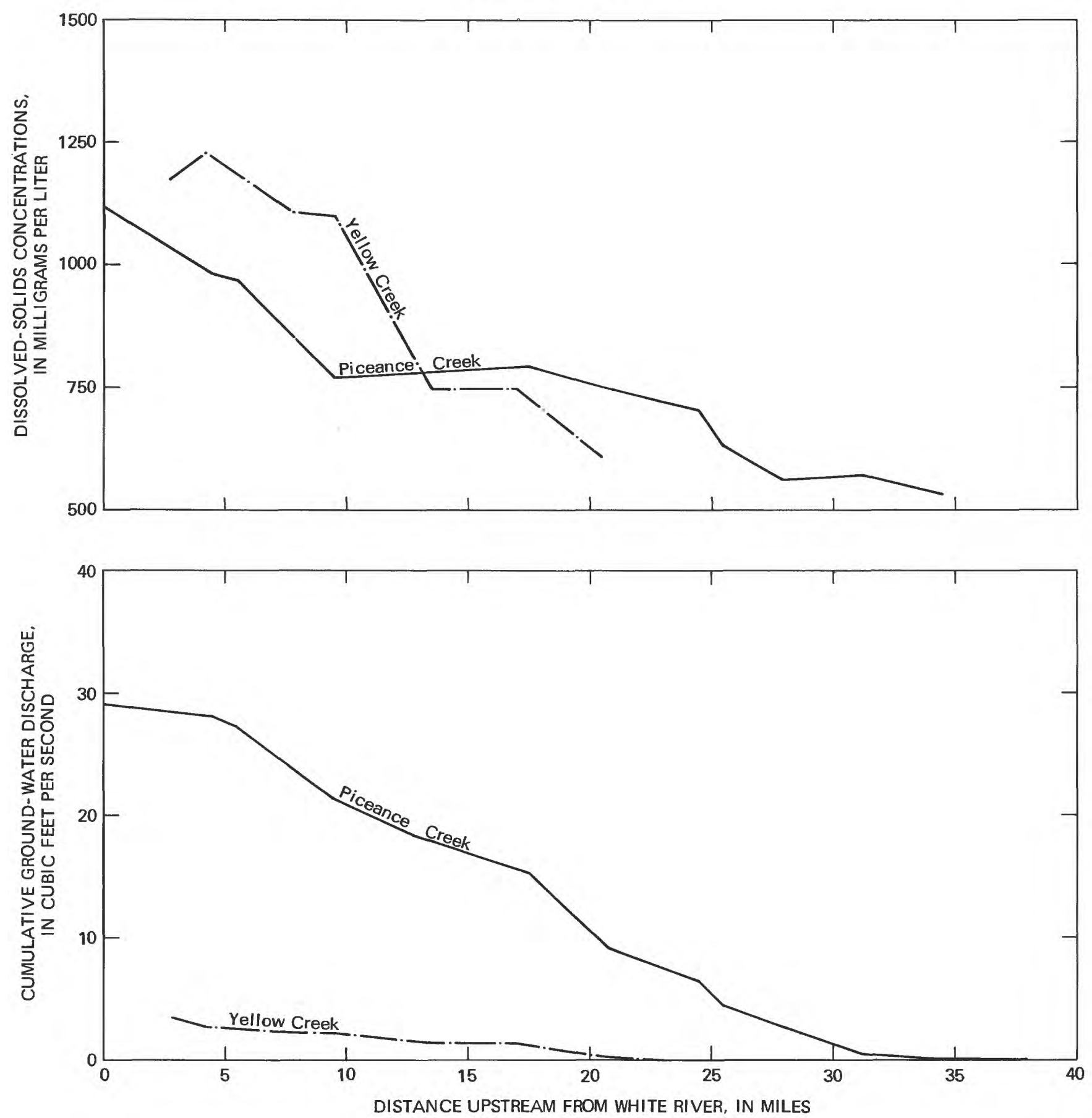

FIgURE 31.-Cumulative ground-water discharge distribution and dissolved-solids concentrations along Piceance and Yellow Creeks.

discharge conditions. If the recharge and discharge conditions include ground-water pumping near an oil-shale mine, the model results will show the effects of this pumping on the potentiometric surface and dissolved-solids concentration in the aquifers. The model thus provides a means of estimating the effects of various hypothetical mining practices and subsequent mine flooding on the water resources of the basin.

The scope of these model simulations is limited by 
the structure of the model and the availability of detailed information about the various mining practices and subsequent mine flooding to be evaluated. The model cannot simulate both confined and watertable storage coefficients; as a result, it will not simulate transient water-table conditions as might occur near a mine being actively dewatered or flooded. Because of this limitation, subsequent model simulations represent equilibrium flow conditions and thus are not affected by the difference between watertable and confined storage coefficients.

In the ground-water model described by Weeks, Leavesley, Welder, and Saulnier (1974), the confined and water-table storage coefficients were taken into consideration, allowing the model to simulate the transient changes in potentiometric heads produced by mine dewatering in tracts $\mathrm{C}-\mathrm{a}$ and $\mathrm{C}-\mathrm{b}$. These model results adequately describe transient conditions during mine dewatering and no attempt was made to duplicate these results using the threedimensional model. Their results indicate that although complete equilibrium conditions may not occur for several centuries after pumping begins, the major change in head occurs within 20 to 30 years after a pumping stress is imposed. Therefore, the equilibrium conditions simulated in the present model probably are reasonable approximations of conditions that would exist in the aquifer at least 30 years after a steady pumping stress commences.

Insufficient data exist to completely describe the future operations of the two mines to be developed in tracts $\mathrm{C}-\mathrm{a}$ and $\mathrm{C}-\mathrm{b}$. As a result, the model simulations are not intended to predict the future hydrologic conditions in the Piceance basin but rather are intended to show the hydrologic conditions that would result if a hypothetical stress were placed on the aquifers near the mining tracts. The simulated mines near tracts C-a and C-b are both $2.2 \mathrm{mi}^{2}$ in area and are located as shown in figures 32 and 39.

The choice of an aquifer porosity of 1 percent also affects the model-simulation results. This conservative value was used in the model so the rate of ground-water movement calculated by the model would tend to be too rapid rather than too slow. The model results, thus, tend to depict a more rapid movement of zones of differing chemical quality than would occur if the effective porosity of the aquifer is larger than 1 percent. In this respect, the model will simulate conditions closer to a "worst case" situation rather than a "best case" situation of contaminant movement.

\section{TRACT C-a}

Current (1978) plans for mining oil shale in tract $\mathrm{C}-\mathrm{a}$ involve the use of modified in-situ retorting procedure in which rubble columns of oil shale are created and retorted in situ. Only a small part of raw shale is removed to provide void space for the rubble and the spent shale is left in place in rubble columns after retorting is completed. Mining activities are to begin with a 10-year modular development phase followed by about 30 years of commercial mining. The interval to be mined is contained in a $3.4 \mathrm{mi}^{2}$ area in the northern part of the tract and extends from near the top of the Mahogany zone (model layer 3 ) to the base of the R-4 zone (Gulf Oil Corp.-Standard Oil Co., 1977). The R-4 zone is a kerogen-rich oil-shale zone located near the middle of the geologic strata included in model layer 5 . Ground water will be pumped to prevent flooding of the mine workings. Mining will occur when the water level near the mine is maintained at a level about $1,000 \mathrm{ft}$ below the initial water level in the tract. The rate of ground-water pumping will increase as the size of the mine expands from the small-scale modular phase to full-scale production. Plans for the modular-development phase indicate that water pumped from the mine will be injected into the bedrock aquifers around the mine to prevent adverse water-level changes away from the tract. Plans for injection during the commercial development phase are not well defined at this time (1978).

\section{MINE DEWATERING}

The model was first used to evaluate the long-term effects of pumping a simulated mine near tract $\mathrm{C}-\mathrm{a}$. It was assumed that water would be pumped from the mine (or wells adjacent to the mine) at a rate which would produce about $1,000 \mathrm{ft}$ of potentiometric-head change in the mine and that no pumped water would be returned to the aquifer. It also was assumed that the water pumped from the mine would be entirely removed from the hydrologic system in the Piceance basin and, thus, have no further effects on the basin. Although this assumption may not be realistic in terms of the actual operational procedure to be used at the mines, it allows the model to simulate the hydrologic impacts of various dewatering practices and subsequent mine flooding without the results being masked by effects of mine-water disposal in the basin. An initial model simulation indicated 
that, when only layer 5 is pumped, vertical (downward) leakage of water through the sediments near tract C-a would adequately lower the heads in model layers 2, 3, and 4 without the need for pumping from these layers. The Uinta Formation near tract $\mathrm{C}-\mathrm{a}$ is not considered to be a significant aquifer; as a result, layer 1 is not considered in the model at tract $\mathbf{C}-\mathbf{a}$.

The model results indicate that a long-term pumping rate of about $5 \mathrm{ft}^{3} / \mathrm{s}$ would be required to produce $1,000 \mathrm{ft}$ of potentiometric-head change in a mine near tract $\mathrm{C}-\mathrm{a}$ with a $2.2 \mathrm{mi}^{2}$ area. The area affected by water-level declines in excess of $1 \mathrm{ft}$ increases from about $370 \mathrm{mi}^{2}$ in layer 2 to $480 \mathrm{mi}^{2}$ in layer 5 (fig. 32). Because these changes represent equilibrium conditions in the basin, the rate of pumping from the mine would be balanced by an equal reduction in groundwater discharge to Yellow Creek and Piceance Creek valleys of about 2 and $3 \mathrm{ft}^{3} / \mathrm{s}$, respectively.

Simulations of various mine-pumping rates indicate that (1) pumping the mine will decrease dissolved-solids concentrations in the water near the mine, and (2) the greater the pumping rate the greater the decrease in dissolved-solids concentrations. Pumping the mine will increase the vertical (downward) and lateral rates of ground-water movement toward the mine. Because the dissolved-solids concentrations in water in the shallow aquifers is less than the concentrations in water in the deeper aquifers, increased downward movement would bring more water with fewer dissolved solids into the deeper part of the aquifer, thereby reducing the dissolvedsolids concentrations in the deeper aquifers. A second factor contributing to these model results is the rate of dissolution of the saline minerals, which is specified in the model as a function of time. The longer ground water remains in contact with a source of dissolution, the greater the dissolved-solids concentrations will become. The increased rate of water movement near the mine would reduce the contact time with local sources of dissolution and thereby would contribute to the reduced dissolvedsolids concentrations. The successful calibration of the model supports the assumption that the rate of saline-mineral dissolution is a function of time. However, dissolution as a function of water velocity or dissolved-solids concentration can occur, but data are not available to determine if these factors have a significant effect on the rate of dissolution in the Piceance basin.

The areal distributions of changes in dissolved- solids concentrations that would be produced by pumping the mine near tract $\mathrm{C}-\mathrm{a}$ at a rate of $5 \mathrm{ft}^{3} / \mathrm{s}$ are shown in figures 33 and 34 . The effects of the mine pumpage on the dissolved-solids concentrations would vary considerably depending on the depth of the aquifer. In layer 2 , for example, a decrease in dissolved-solids concentrations would occur in a $240-\mathrm{mi}^{2}$ area around the simulated mine (fig. $33)$. In layer 5 , the altered rates of ground-water flow would produce a decrease in dissolved-solids concentrations in a $140-\mathrm{mi}^{2}$ area extending from the mine to Piceance Creek. A small area of increase in dissolved-solids concentrations of less than $50 \mathrm{mg} / \mathrm{L}$ would occur to the east of the mine, and a large area of increase of more than $400 \mathrm{mg} / \mathrm{L}$ would occur downgradient (northeast) from the mine. The changes in dissolved-solids concentrations for layers 3 and 4 would be of intermediate values between those shown for layers 2 and 5. Model results based on other pumping rates indicate that as the mine pumping rate increases or decreases, the magnitude of change in dissolved-solids concentrations will increase or decrease, and the size of the area affected by these changes also will increase or decrease.

Under equilibrium conditions, the volume of water pumped from the mine would be exactly balanced by a reduction in the rate of natural discharge from the basin. If the mine were pumped at $5 \mathrm{ft}^{3} / \mathrm{s}$, groundwater discharge in Yellow Creek drainage would be reduced from 3.5 to $1.4 \mathrm{ft}^{3} / \mathrm{s}$ and the ground-water discharge in Piceance Creek drainage would be reduced from 29 to $26 \mathrm{ft}^{3} / \mathrm{s}$. The distribution and chemical quality of cumulative ground-water discharge in Yellow Creek valley before and after the mine is pumped are shown in figure 35 . The model does not separate the baseflow, underflow, or evapotranspiration components of ground-water discharge. As a result, the surface flow in Yellow Creek is not directly calculated by the model. However, the model-calculated cumulative ground-water discharge figures give an approximation of surface-water flow and chemical quality without taking into consideration the effects of precipitation runoff, evapotranspiration, or ground-water underflow in the valley alluvium.

The most upgradient area of ground-water discharge to Yellow Creek valley occurs 20 to $23 \mathrm{mi}$ upstream from the confluence with the White River under the initial or present-day conditions. After the basin reaches equilibrium with the pumping from the 
EXPLANATION

LINE OF EQUAL WATER LEVEL
DECLINE - Interval, in feet, is variable

AREA OF SIMULATED MINE

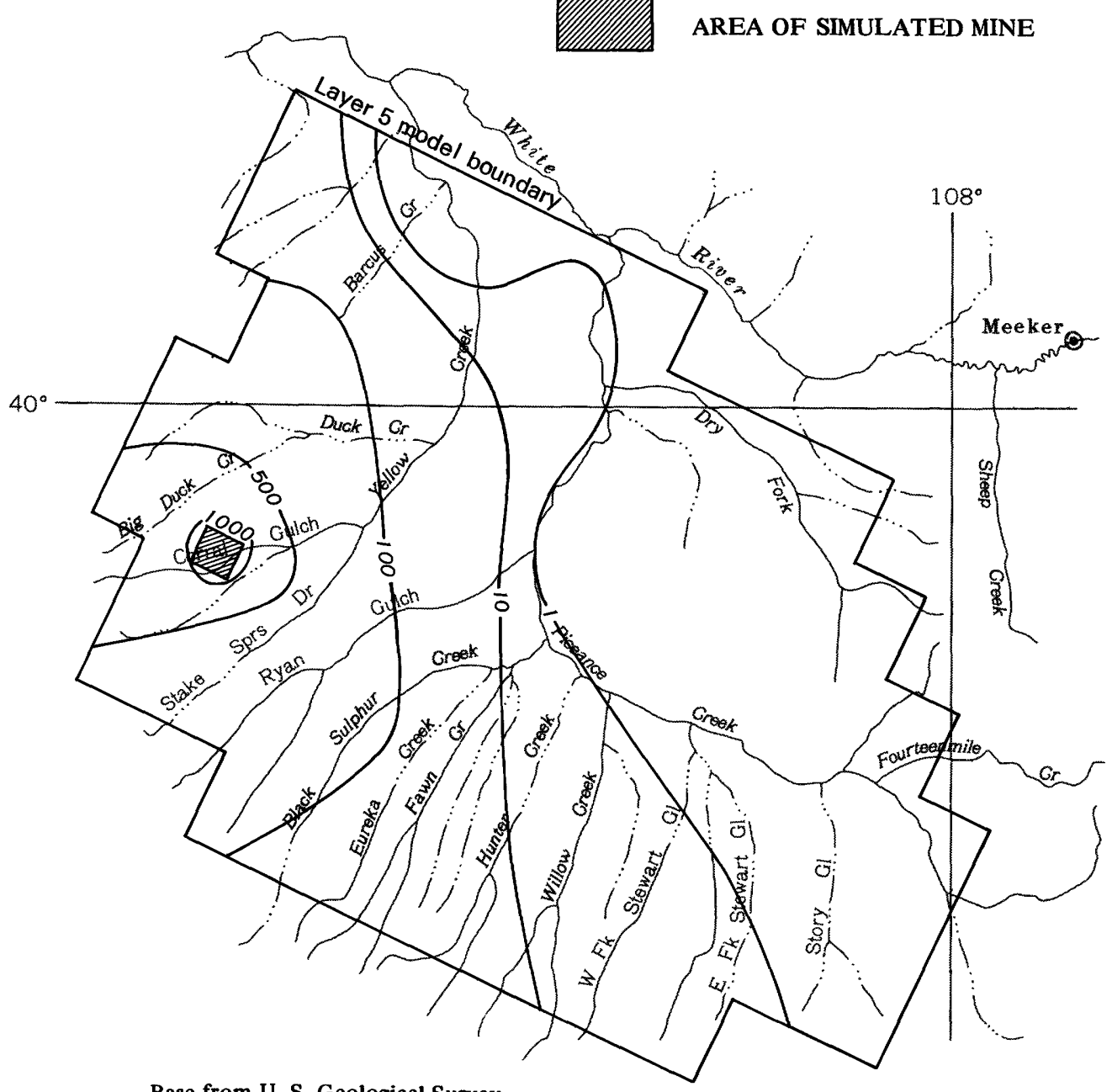

Base from U. S. Geological Survey State base map, 1969

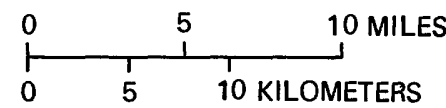

Figure 32.-Model-calculated drawdown in layer 5 produced by pumping mine near tract C-a at 5 cubic feet per second.

mine near tract $\mathrm{C}-\mathrm{a}$, the most upgradient area of ground-water discharge to Yellow Creek valley will be shifted downgradient, occurring 9 to $13 \mathrm{mi}$ upstream from the White River. The dissolved-solids concentrations will increase from 1,100 to 1,900 $\mathrm{mg} / \mathrm{L} 8 \mathrm{mi}$ upstream from the White River as a result of the loss of the water that initially discharged into the upper reaches of the valley.

The inability of the model to simulate transient- flow conditions involving both confined and watertable storage coefficients limits its use in evaluating the effects of injection of ground water pumped from a mine. Although the pumping-injection procedure is primarily a transient ground-water flow problem, a special case exists in which the injection rate is controlled so as to maintain equilibrium conditions in the remainder of the ground-water basin outside of the mine. The simulation of these large-scale equili- 


\section{EXPLANATION}

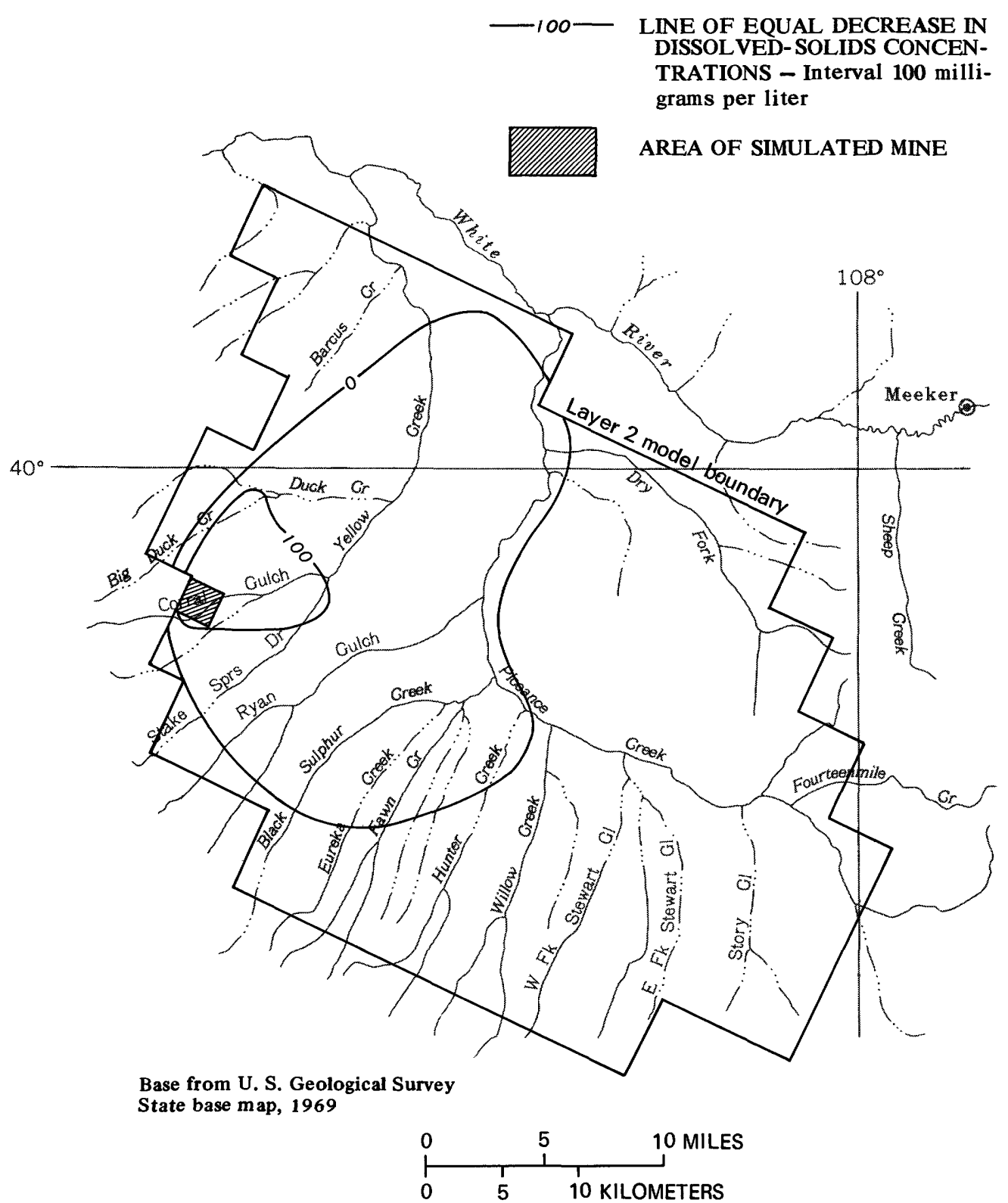

FIGURE 33.-Model-calculated decrease in dissolved-solids concentrations in layer 2 produced by pumping mine near tract $\mathrm{C}-\mathrm{a}$ at 5 cubic feet per second.

brium conditions would be within the capability of the model were it not for the importance of smallscale conditions within the mine. The chemical quality of the injected water, for example, is determined by small-scale conditions that cannot be properly simulated with this model. If the chemical quality of the injected water is predetermined, the model can be used to show the effects of injecting water of different chemical quality into the equilibrium ground-water flow field in the Piceance basin. Separate model simulations of this special case of the injection problem were not made because virtually identical model simulations are required to simulate the effects of spent oil-shale leaching in an abandoned and flooded mine. The mine-leaching simulations can be considered to represent injection simulations in which the dissolved-solids concentrations of the injected water are greater than that of the ground water. 


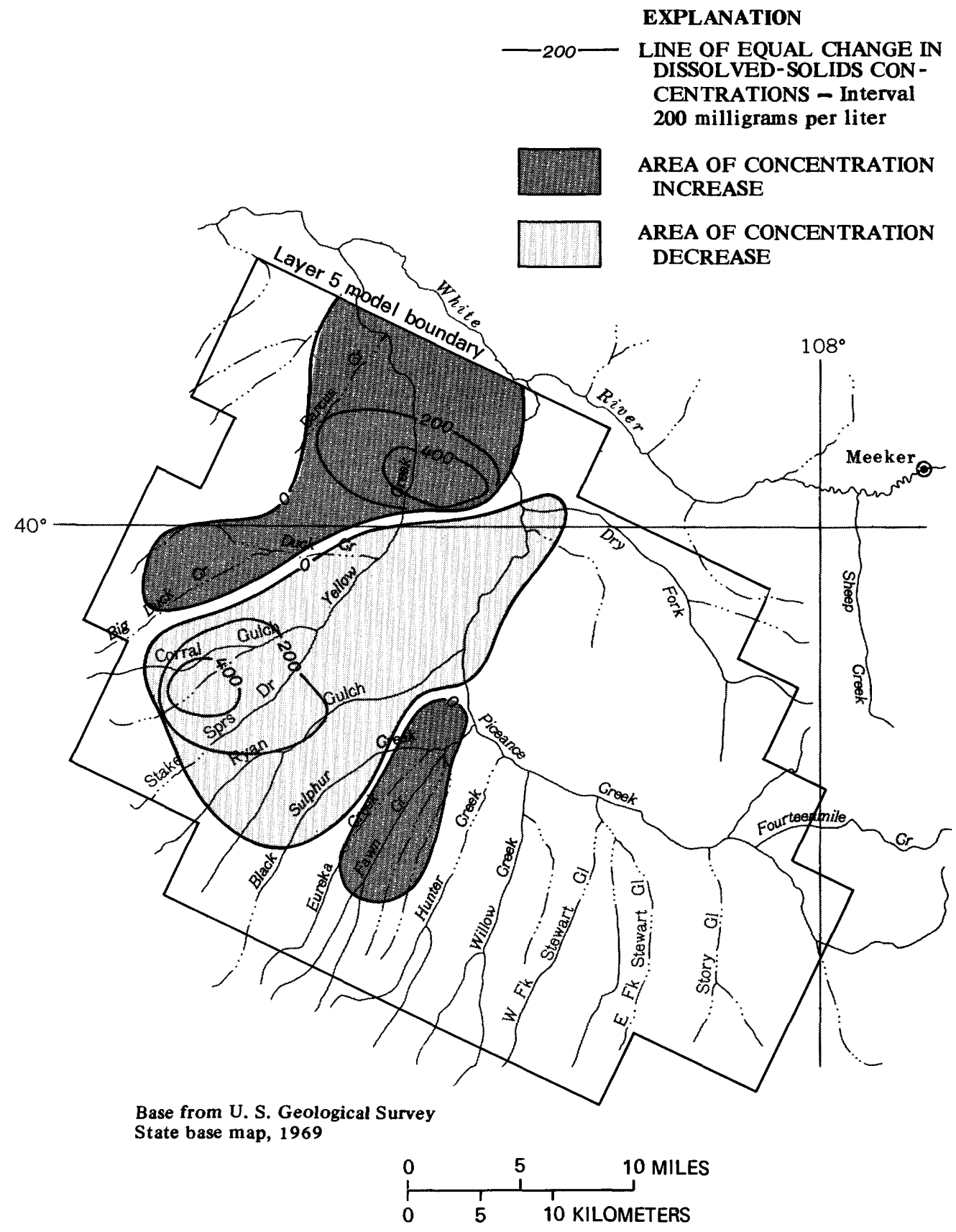

FIGURE 34.-Model-calculated change in dissolved-solids concentrations in layer 5 produced by pumping mine near tract $\mathrm{C}-\mathrm{a}$ at 5 cubic feet per second.

\section{MINE FLOODING}

The next group of model simulations were made to investigate the effects of flooding of an abandoned mine near tract $\mathrm{C}-\mathrm{a}$ containing large quantities of spent shale in underground retorts. In these simulations, it was assumed that the radial flow of water toward the mine, during the time the cone of depression around the mine would be filling, will effectively halt any migration of ground water away from the saline minerals in the spent shale in the mine. In effect, it was assumed that no poor-quality ground water would move away from the abandoned mine until the aquifer returns to the equilibrium conditions that occurred prior to pumping the mine. This is thought by the authors to be a reasonable assumption even though in actuality some movement might occur before complete equilibrium exists. For these simulations, leaching is assumed to begin when leachate moves into the aquifers outside of the mine. The 

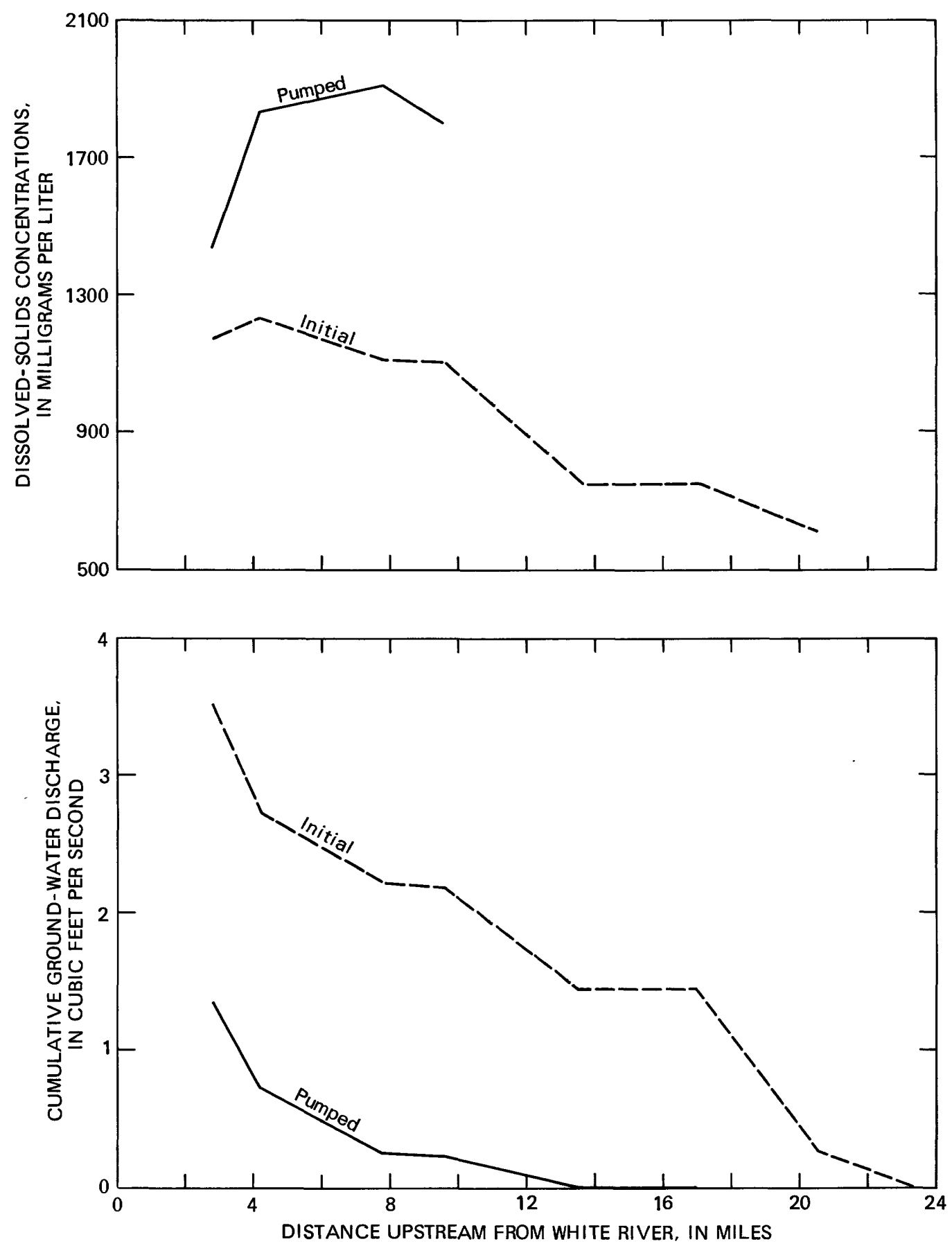

FIGURE 35.-Change in model-calculated ground-water discharge and dissolved-solids concentrations in Yellow Creek valley produced by pumping mine near tract $\mathrm{C}-\mathrm{a}$ at 5 cubic feet per second.

simulations differ from those simulating mine pumping in that the model calculates transient (timevarying) concentration conditions that would occur in an equilibrium or steady-state flow system.

As mentioned previously, spent oil shale may contain soluble saline minerals in concentrations ranging from 1 to 5 percent by weight. The rate of dissolution of these minerals by ground water will be affected by indeterminate factors, such as retorting temperatures, shale particle size, and permeability of the retorts. Management of the oil-shale mines during and after the retorting operations can drastically affect these factors and, thus, the rate of dissolution that will occur in the abandoned and flooded mine.

The model was used to determine the effects of 
various mine-leaching rates since the actual rate to be expected is not known. The change in dissolvedsolids concentrations after 60 years of leaching, shown in figure 36 , is calculated from initial conditions in the basin aquifers prior to the effects of mine pumping. As shown, the mine leachate would have the most pronounced effect on the water quality in the layer with the largest hydraulic conductivity (layer 2) and the least effect in the layer with the smallest hydraulic conductivity (layer 3). Dissolved-solids concentrations as much as $50,000 \mathrm{mg} / \mathrm{L}$ would occur in layer 2 adjacent to the mine after 60 years of leaching at rates that are thought to be possible for an actual mine in tract $\mathbf{C}-\mathbf{a}$.

The longer the mine leaching continues, the more pronounced the water-quality changes in the aquifer will become. The change in dissolved-solids concentrations in each model layer for 60 years of constant mine leaching at a rate of $1.3 \times 10^{5} \mathrm{lb} / \mathrm{d}$ is shown in figure 37. The large volume of water initially in and near the simulated mine containing relatively small concentrations of dissolved solids would mix with the influx of mine leachate to produce the gradual change in water quality shown. Throughout the 60 year simulation period, the layers with the largest hydraulic conductivity show the largest change in concentration.

The areal distribution of the water-quality change in layer 2 is shown in figure 38. Dissolved-solids concentrations will increase by more than 1,000 $\mathrm{mg} / \mathrm{L}$ in a $30-\mathrm{mi}^{2}$ area downgradient from the mine after 60 years of mine leaching. Dissolved-solids increases in excess of $10 \mathrm{mg} / \mathrm{L}$ will occur in a $140-\mathrm{mi}^{2}$ area. As indicated by the changes shown in figure 37, the areas affected by water-quality changes in the other model layers would be smaller than the areas in layer 2. Only minor changes in water quality in Yellow Creek will result after 60 years of leaching, primarily because water with relatively large dissolved-solids concentrations will not have reached the main areas of ground-water discharge along the creek.

If the mine is managed so as to minimize the rate of dissolution of the saline minerals in the abandoned retorts, the effects on the ground-water quality could be much less significant than those shown by these model simulations. Conversely, disregard for spentshale leaching problems could lead to a serious and long-term degradation in the ground-water quality in Piceance basin.

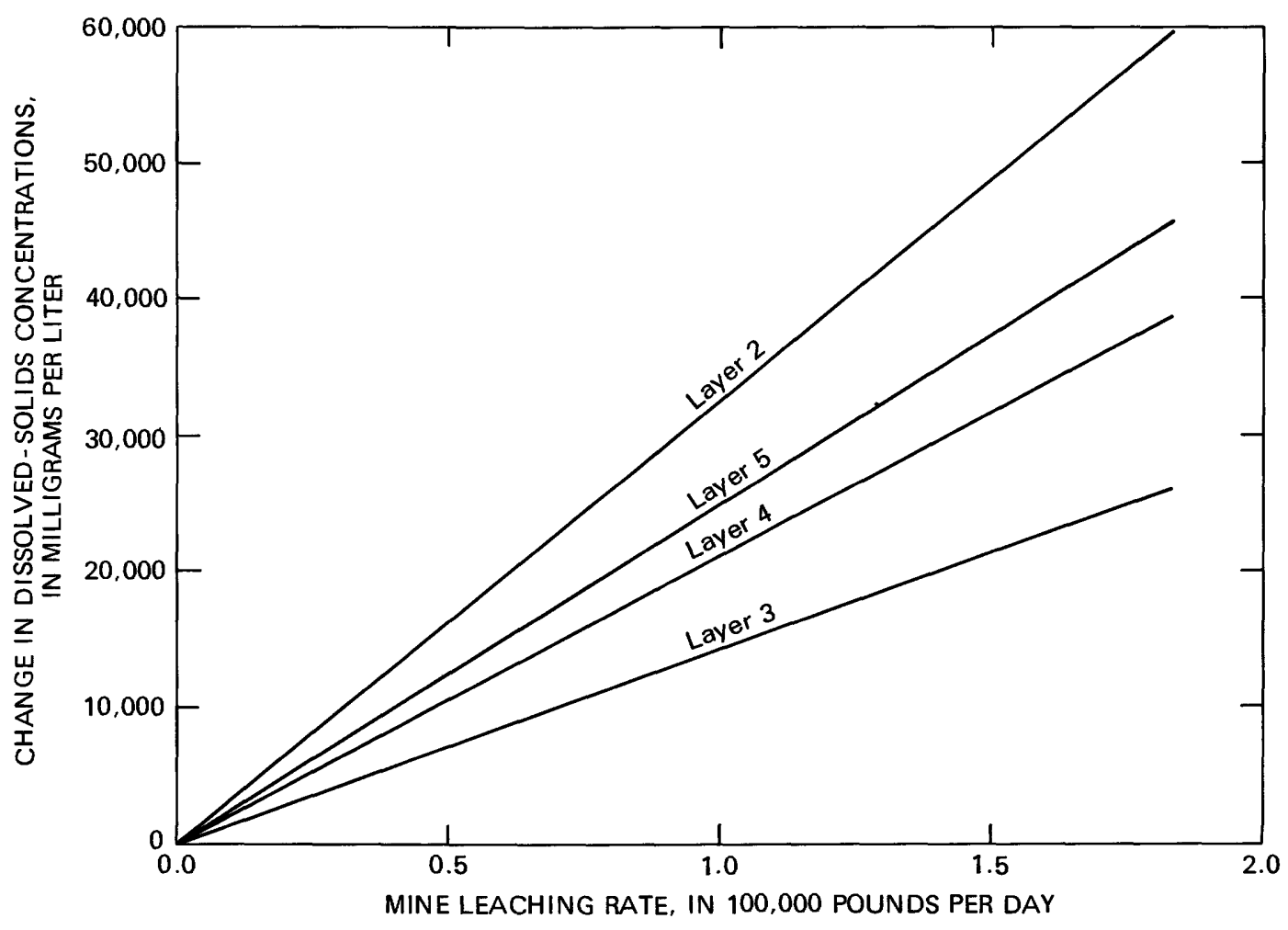

FIGURE 36.-Change in dissolved-solids concentrations in aquifers adjacent to abandoned mine near tract $\mathrm{C}-\mathrm{a}$ after 60 years of leaching. 


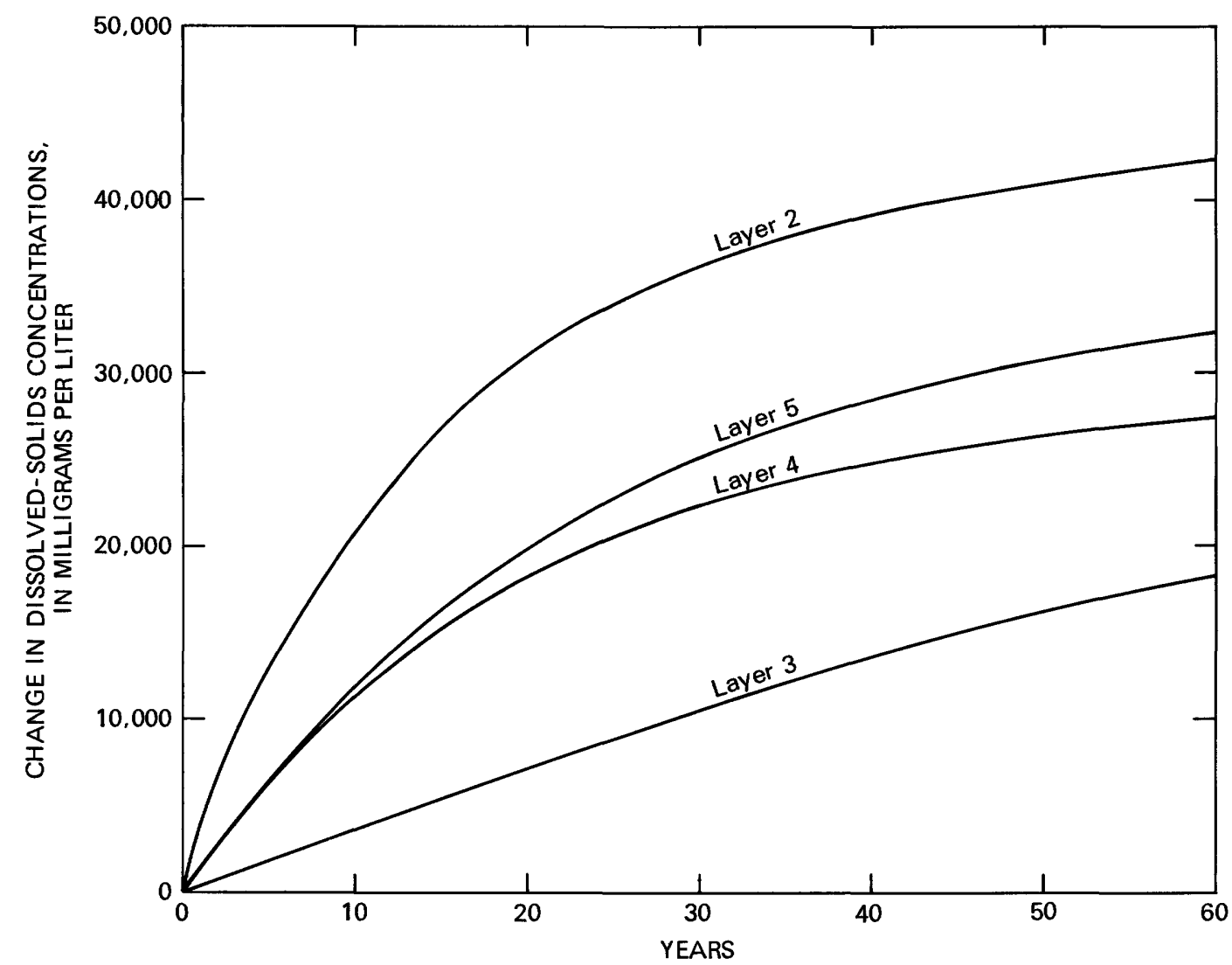

FIGURE 37.-Change in dissolved-solids concentrations with time in aquifers adjacent to abandoned mine for leaching rate of $1.3 \times 10^{5}$ pounds per day.

TRACT C-b

Plans for mining oil shale in tract $\mathrm{C}-\mathrm{b}$ are similar to the planned mining in tract $\mathrm{C}$ - $\mathrm{a}$ in that a modified in-situ retorting procedure will be used. Mining operations are expected to continue for about 60 years with the size of the mine increasing about 0.12 $\mathrm{mi}^{2} /$ years to an ultimate area of about $7 \mathrm{mi}^{2}$. The mining interval extends from just above the Mahogany zone, in model layer 2 , to just below the top of model layer 5 , a vertical distance of about $500 \mathrm{ft}$ (Ashland Oil, Inc., Occidental Oil Shale, Inc., 1977). Ground water will be pumped from the mine to lower the water level in the mine about $1,400 \mathrm{ft}$ to prevent flooding of the mine workings. Plans for disposal of the pumped water are not definite at present (1978), but possibilities include injection into the aquifers, discharge to Piceance Creek, or other off-tract discharge options.

\section{MINE DEWATERING}

The model was used to evaluate the effects of longterm pumping from a simulated mine in tract $\mathrm{C}-\mathrm{b}$. It was assumed that a $2.2-\mathrm{mi}^{2}$ area mine would with- draw water from model layers 2 through 5 and that the pumped water would not be returned to the aquifer. The relative yield of each model layer to the simulated mine is shown in table 4. As shown, model layers 2 through 5 .would contribute water directly to the mine, with layers 2 and 5 contributing the majority of the water due to the larger hydraulic conductivity of these two layers. This is in contrast to the model results for tract $\mathrm{C}-\mathrm{a}$ which indicate that water would not flow directly into the mine from layers 2 through 4 when layer 5 was pumped to maintain the required water level in that layer.

TABLE 4.-Distribution of total pumpage by model layer for tract $\mathbf{C}-\boldsymbol{b}$

\begin{tabular}{|c|c|}
\hline Model layer & $\begin{array}{l}\text { Percentage of } \\
\text { total pumpage }\end{array}$ \\
\hline 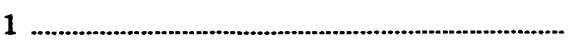 & 0.0 \\
\hline 2 & 41.2 \\
\hline 3 & 3.4 \\
\hline 4 & 9.9 \\
\hline 5 & 45.5 \\
\hline
\end{tabular}




\section{EXPLANATION}
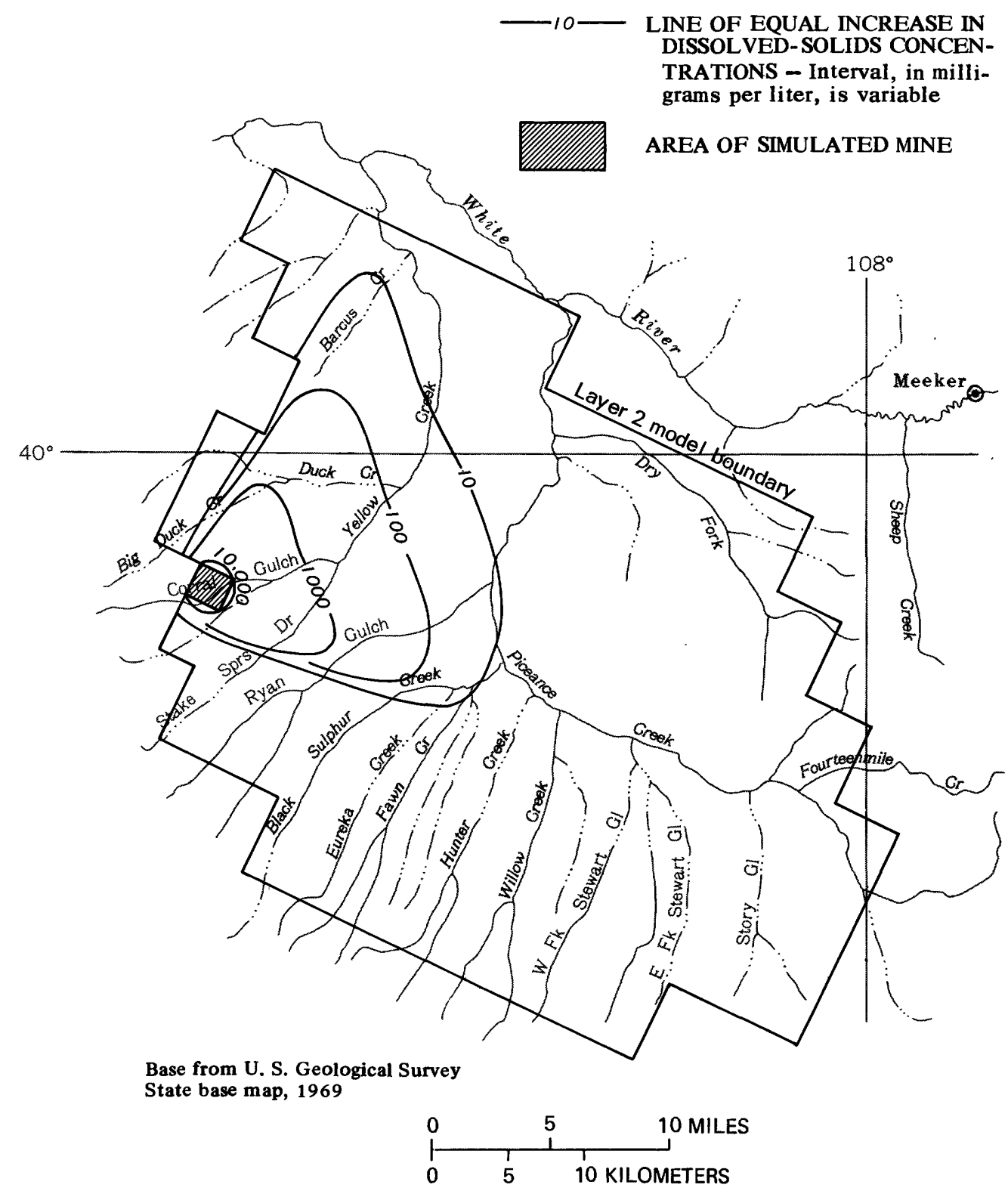

FIGURE 38.-Model-calculated increase in dissolved-solids concentrations in layer 2 after 60 years of leaching from abandoned mine at $1.3 \times 10^{5}$ pounds per day.

It was determined that a long-term mine-pumping rate of about $15 \mathrm{ft}^{3} / \mathrm{s}$ will be needed to maintain the required $1,400-\mathrm{ft}$ water-level decline in layer 5 in tract $\mathrm{C}-\mathrm{b}$. The distribution of pumping shown in table 4 produced about $800,900,1,100,1,200$, and $1,400 \mathrm{ft}$ of water-level decline in tract $\mathrm{C}-\mathrm{b}$ in model layers 1 through 5 , respectively. Water-level declines in layer 5 in excess of $1 \mathrm{ft}$ will occur in a $560-\mathrm{mi}^{2}$ area of the Piceance basin with declines in excess of $100 \mathrm{ft}$ occurring in a $240-\mathrm{mi}^{2}$ area in the southern part of the basin (fig. 39). Progressively smaller areas of equal water-level decline will occur in the layers above layer 5. In layer 1 , for example, declines in excess of 1 $\mathrm{ft}$ will occur in a $410-\mathrm{mi}^{2}$ area.

Simulations were made using different mine-pumping rates to show the long-term effects of the pumping on the water quality in the aquifers. Results of these simulations indicate that, as the mine-pumping rate increases, the dissolved-solids concentration near the mine in model layers 1,2 , and 3 will remain 

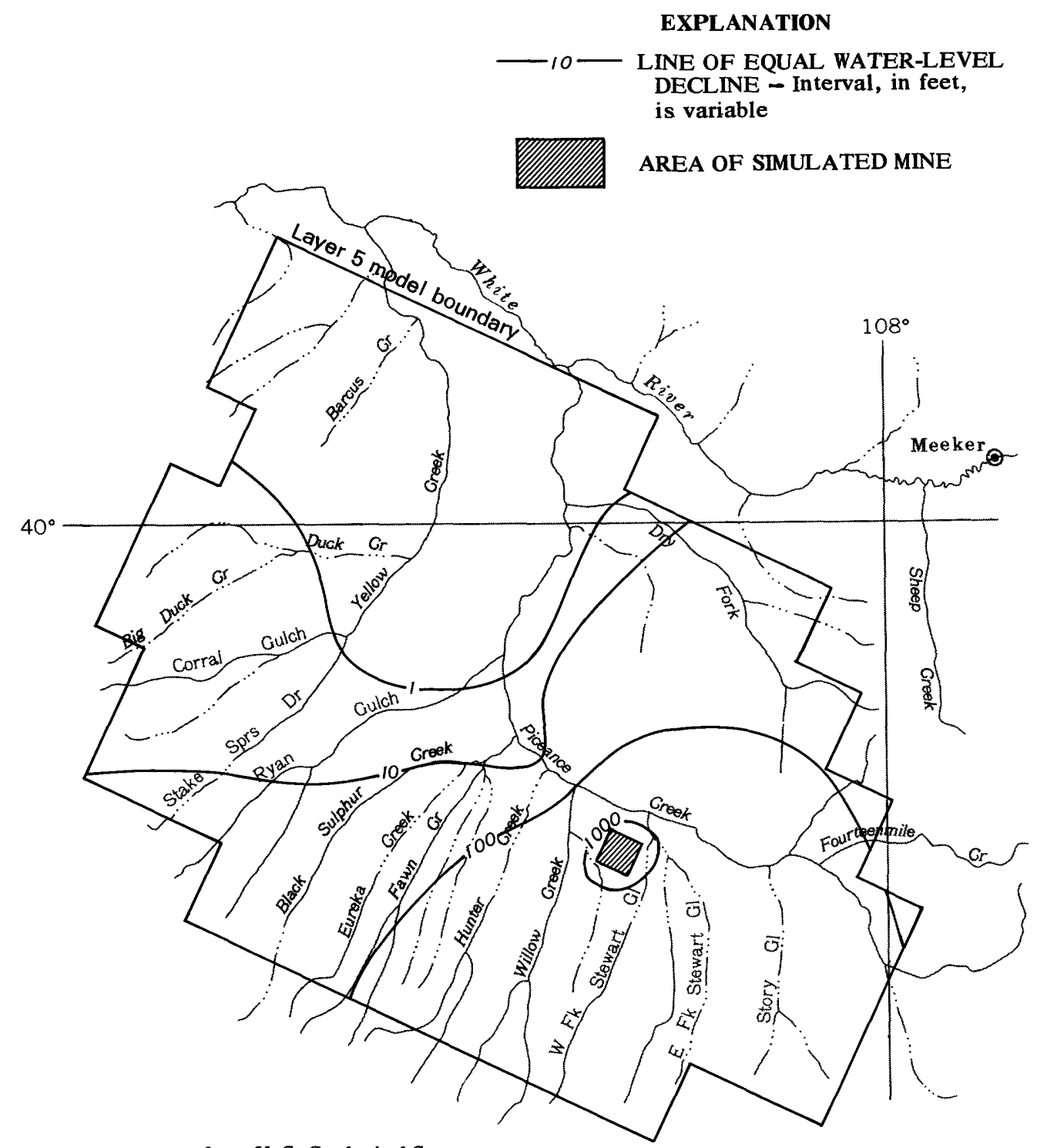

Base from U. S. Geological Survey State base map, 1969

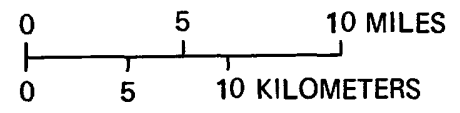

FIGURE 39.-Model-calculated drawdown in layer 5 produced by pumping mine in tract $\mathrm{C}-\mathrm{b}$ at 15 cubic feet per second.

constant and only a small reduction in concentration will occur in layer 4. Concentrations near the mine in layer 5 , however, show a marked decrease in response to increased rates of pumping. A decrease in dissolved-solids concentrations of as much as 1,100 $\mathrm{mg} / \mathrm{L}$ will occur in layer 5 when the mine is pumped at a rate of $15 \mathrm{ft}^{3} / \mathrm{s}$. The decrease in dissolved-solids concentrations in layer 5 will occur in a $120-\mathrm{mi}^{2}$ area (fig. 40) around the simulated mine and would be adjacent to a $90-\mathrm{mi}^{2}$ area in which the dissolved- solids concentration will increase by as much as 50 $\mathrm{mg} / \mathrm{L}$. As discussed previously with respect to tract $\mathrm{C}-\mathrm{a}$, the change in concentration calculated by the model is due primarily to the altered rate and direction of ground-water movement.

Under the equilibrium conditions simulated in these model calculations, the volume of water pumped from the mine would be exactly balanced by a reduction in the rate of ground-water discharge. The proximity of tract C-b to Piceance Creek will cause 


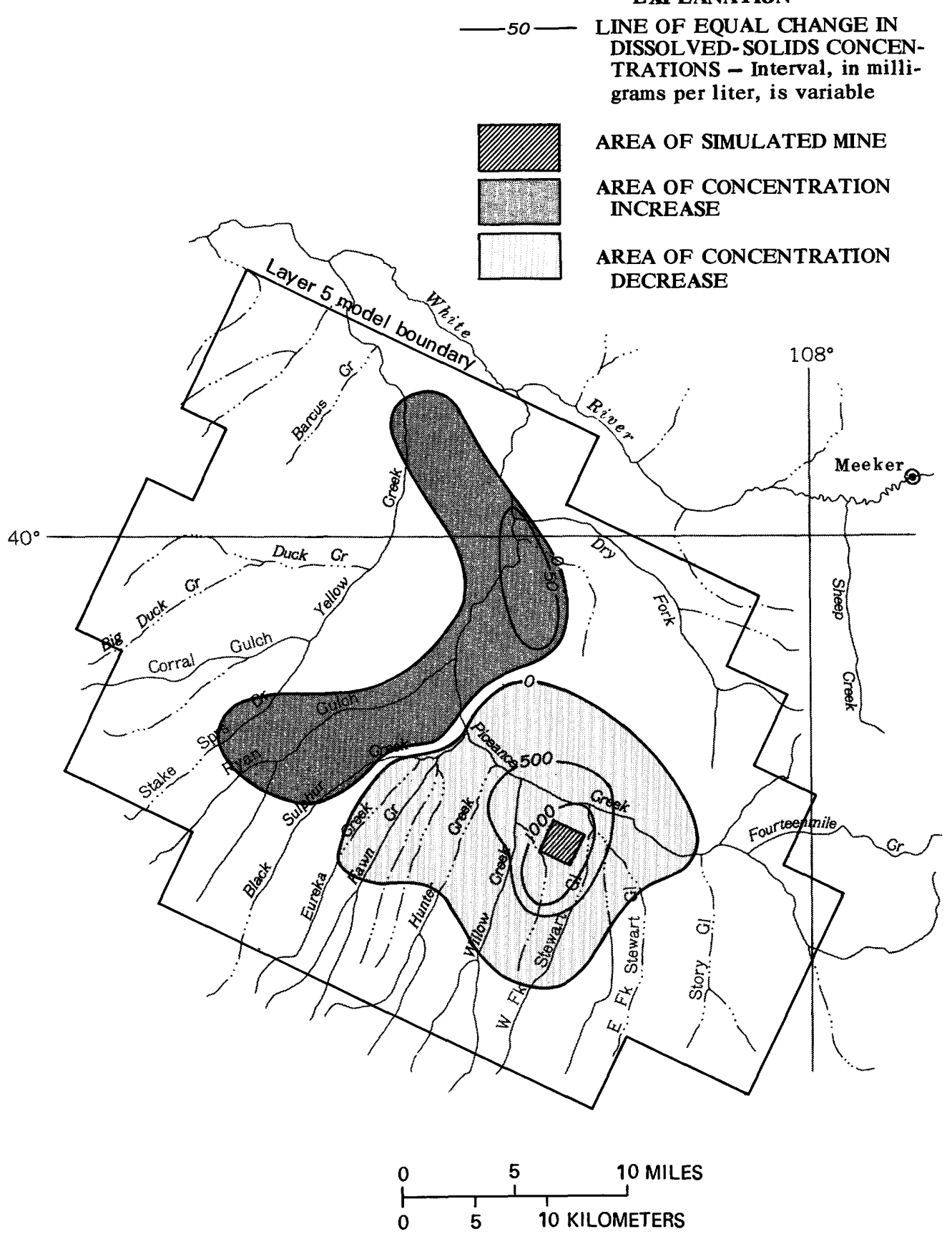

FIGURE 40.-Model-calculated change in dissolved-solids concentrations in layer 5 produced by pumping mine in tract $\mathrm{C}-\mathrm{b}$ at $\mathbf{1 5}$ cubic feet per second.

the reduction in ground-water discharge to affect only Piceance Creek. The model does not separate the baseflow, underflow, and evapotranspiration components of ground-water discharge. As a result, the surface flow in Piceance Creek is not directly calculated by the model. Therefore, the cumulative ground-water discharge figures represent the estimated surface flow in Piceance Creek without con- sideration for precipitation runoff, evapotranspiration loss, or ground-water underflow in the valley alluvium. If the mine were pumped at $15 \mathrm{ft}^{3} / \mathrm{s}$, the cumulative ground-water discharge at the mouth of Piceance Creek would be reduced $15 \mathrm{ft}^{3} / \mathrm{s}$ due to loss of ground-water discharge to the valley along a reach 18 to $30 \mathrm{mi}$ upstream from the White River (fig. 41). The resulting concentration profile down the valley also 

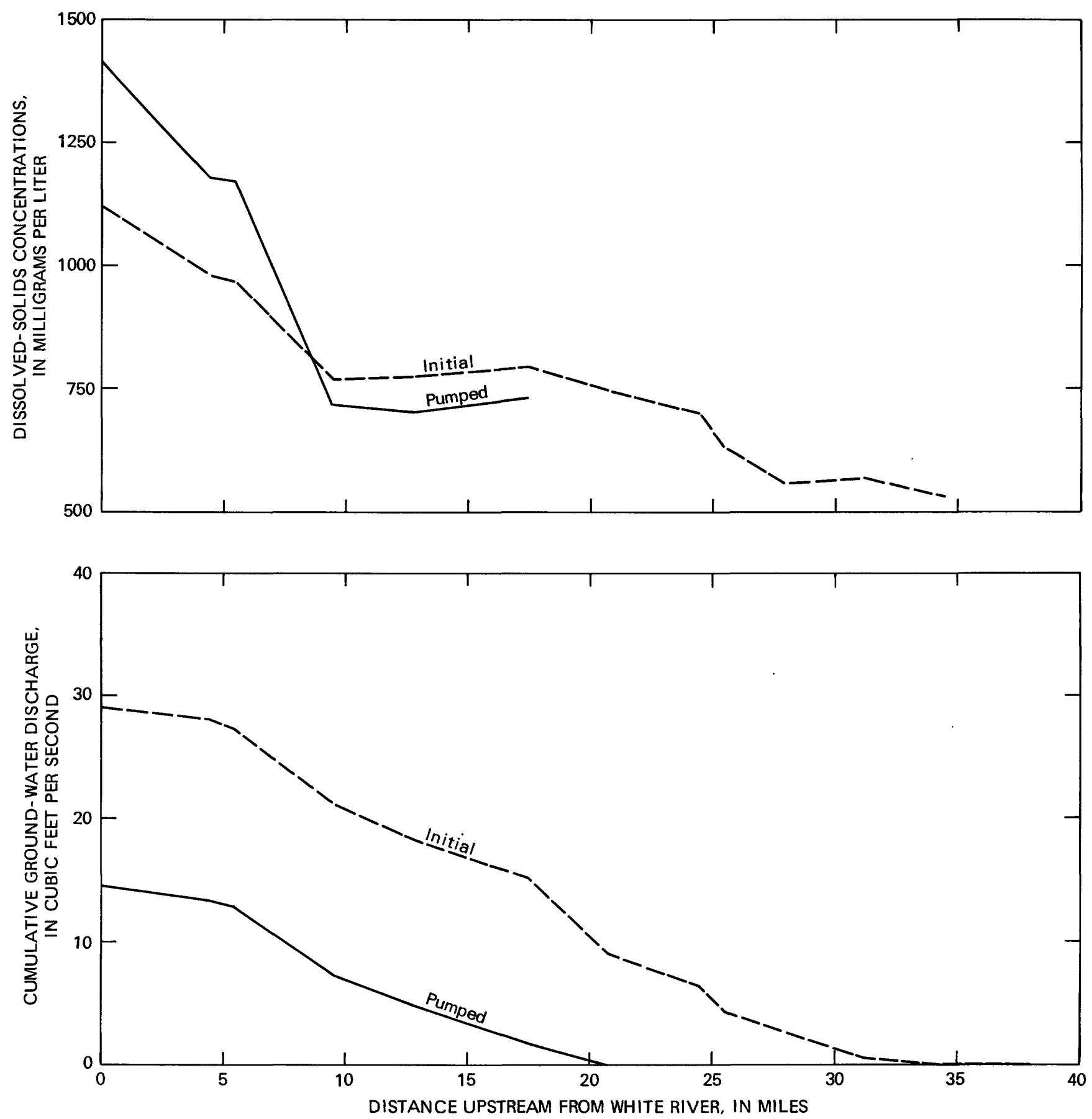

FIGURE 41.-Change in model-calculated ground-water discharge and dissolved-solids concentrations in Piceance Creek valley produced by pumping mine in tract $\mathrm{C}-\mathrm{b}$ at 15 cubic feet per second.

is shown on figure 41 and indicates that the dissolvedsolids concentration of the cumulative ground-water discharge will be increased from about 1,100 to 1,400 $\mathrm{mg} / \mathrm{L}$ in the lower reach of the stream valley as a result of pumping the mine in tract $\mathrm{C}-\mathrm{b}$. This increase would be due to the loss of better quality ground-water discharge to the stream valley near tract $C-b$, coupled with no change in the rate of poorer quality ground-water discharge to the lower reaches of the valley. The cumulative ground-water discharge and dissolved-solids concentrations presented in figure 41 were computed in the same manner as those shown in figure 35 for Yellow Creek. 


\section{MINE FLOODING}

Model simulations also were made to investigate the ground-water quality changes that could occur as a result of leaching of spent shale left in an abandoned mine in tract C-b. As for tract C-a, these simulations were based on the assumption that insignificant movement of mine leachate would occur prior to the time the water levels around the mine returned to near equilibrium (prepumping) conditions. These model simulations depict transient concentration conditions that would occur in an equilibrium groundwater flow field.

The rate of dissolution of saline minerals in the spent shale in tract $\mathrm{C}-\mathrm{b}$ will be affected to a major extent by mining practices and subsequent steps taken prior to the closure of the mine. Specific information about these factors is tenuous at this time (1978) and an accurate estimate of the rate of mine leaching cannot be made. Consequently, the model was used to investigate the effects of various mineleaching rates on the ground-water quality near the mine. Model results shown in figure 42 indicate that, for a given leaching rate, the largest concentration changes will occur in layers 4 and 5 . Layer 1 , by contrast, would be little affected by the range of leaching rates considered. At a leaching rate of $1.3 \times$ $10^{5} \mathrm{lb} / \mathrm{d}$, an increase in dissolved-solids concentrations in excess of $20,000 \mathrm{mg} / \mathrm{L}$ would occur in some of the water near the mine after 60 years of leaching. A comparison of the effects of leaching in tracts $\mathrm{C}-\mathrm{a}$ (fig. 36) and C-b (fig. 42) shows that the water quality will be more readily degraded near tract $\mathrm{C}-\mathrm{a}$. For a given leaching rate, the same mass of salt will be introduced to the water in each tract, but the larger volume of water containing relatively small concentrations of dissolved solids that would move through the tract $\mathrm{C}-\mathrm{b}$ area will produce more dilution. Thus, although the water near tract $\mathrm{C}-\mathrm{b}$ will carry the same salt load as that in tract C-a (for identical leaching rates), the resultant dissolved-solids concentrations of the water near tract $C-b$ will be less.

The effect of a given mine-leaching rate on the dissolved-solids concentrations in an aquifer will become more pronounced the longer the leaching continues. This effect is shown for tract $\mathrm{C}-\mathrm{b}$ in figure 43. The concentration changes will occur more quickly in the more permeable layers-layers 2,4 , and 5 . After 60 years of leaching, the concentrations in layers 1 and 2 would be at or near an equilibrium level, while the concentrations would still increase steadily in layers 3,4 , and 5 . A comparison of data in figures 37 and 43 indicates that, for equal mine leaching rates, the changes in ground-water quality will occur more rapidly near the simulated mine in tract $\mathrm{C}-\mathrm{a}$ than near the simulated mine in tract $\mathrm{C}-\mathrm{b}$.

The areal distribution of increased dissolvedsolids concentration in layers 4 and 5 after 60 years of mine leaching at a rate of $1.3 \times 10^{5} \mathrm{lb} / \mathrm{d}$ is shown in

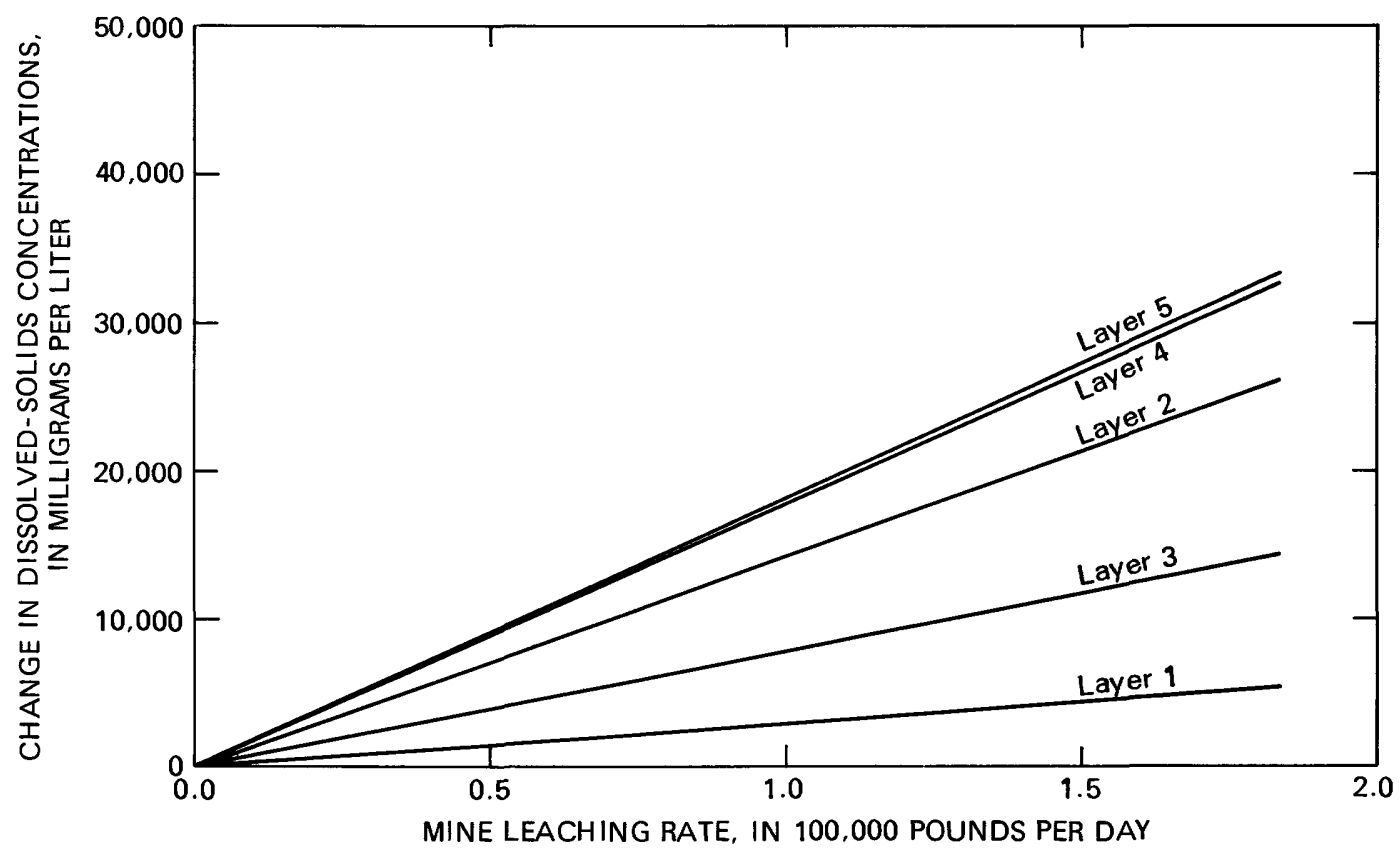

FIGURE 42,-Change in dissolved-solids concentrations in aquifers adjacent to abandoned mine in tract C-b after 60 years of leaching. 


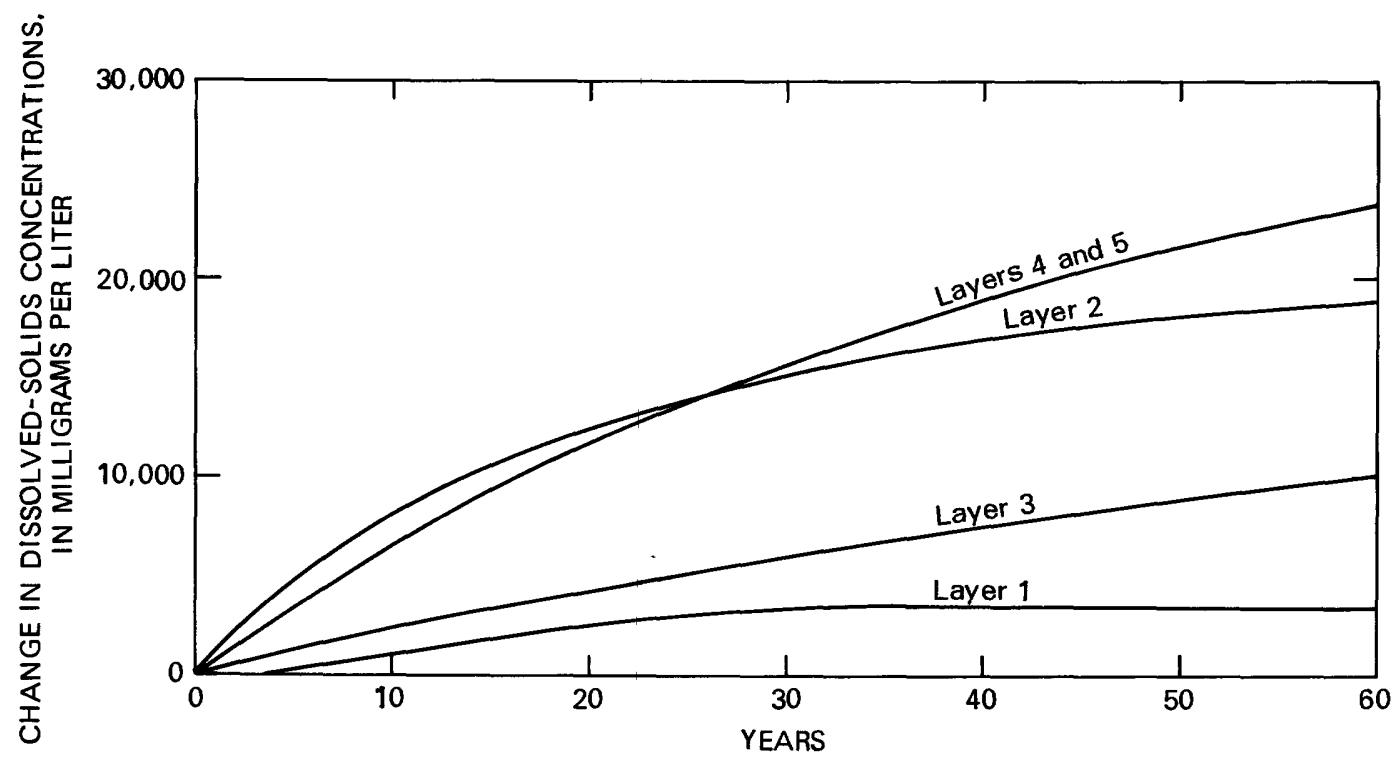

FIGURE 43.-Change in dissolved-solids concentrations with time in aquifers adjacent to abandoned mine in tract $\mathrm{C}-\mathrm{b}$ for leaching rate of $1.3 \times 10^{5}$ pounds per day.

figure 44. As indicated in figures 42 and 43, layers 4 and 5 would be more severely affected by waterquality changes than would the other layers. The concentration changes will be primarily localized near the mine and along the south side of Piceance Creek. The area subject to dissolved-solids increases greater than $10 \mathrm{mg} / \mathrm{L}$ would be only about $40 \mathrm{mi}^{2}$ in size, in contrast to the $140-\mathrm{mi}^{2}$ area that would be affected by identical concentration changes produced under similar conditions in tract C-a (fig. 38). The reason for the smaller zone of influence near tract $C-b$ is two-fold. First, as has already been discussed, the larger volume of water moving through the aquifers near tract $C-b$ would produce more dilution of the mine leachate, thereby decreasing the size of the zone of degraded water. The second and more significant factor is the location of Piceance Creek with respect to tract C-b. Ground water moving near tract $\mathrm{C}-\mathrm{b}$ is able to travel only a few miles before being discharged to the alluvial aquifer or surface flow in Piceance Creek. As a result, the degraded water near the mine would affect the surrounding ground-water quality in only a limited area before being removed from the aquifer system by the surface drainage.

Previous simulations have shown that pumping the mine in tract $C-b$ would have a pronounced effect on the volume of ground-water discharge to Piceance Creek valley. In a like manner, leaching of the mine in tract $\mathrm{C}-\mathrm{b}$ would have a pronounced effect on the water quality in the valley. The dissolved-solids con- centration profile (fig. 45) shows that an increase in dissolved-solids concentration from 750 to $1,750 \mathrm{mg} / \mathrm{L}$ would occur in the cumulative ground-water discharge near tract $\mathrm{C}-\mathrm{b}$. The dissolved-solids concentrations in the cumulative discharge at the mouth of Piceance Creek valley would be increased from 1,100 to $1,450 \mathrm{mg} / \mathrm{L}$ as a result of mine leachate from tract $\mathrm{C}-\mathrm{b}$. The cumulative ground-water discharge calculated by the model would be representative of streamflow if adjustments were made for surface runoff, evapotranspiration, and ground-water underflow in the valley alluvium as has been described previously with respect to tract $\mathrm{C}-\mathrm{a}$ and Yellow Creek.

If the mine in tract $\mathrm{C}-\mathrm{b}$ is managed so as to minimize the rate of dissolution of the saline minerals in the abandoned retorts, the effects on the groundwater quality could be much less significant than those shown by the model simulations that used a $1.3 \times 10^{5} \mathrm{lb} / \mathrm{d}$ leaching rate. Conversely, disregard for spent-shale leaching problems could lead to a serious and long-term degradation of the ground- and surfacewater quality in the basin.

Equal rates of leaching of abandoned mines in tracts $\mathrm{C}-\mathrm{a}$ and $\mathrm{C}-\mathrm{b}$ will likely produce much different effects on the water resources of Piceance basin. Tract $C-a$, by virtue of its remote location from perennial streams, primarily will affect the ground-water quality in a large area to the northeast of the tract. Tract C-b, by contrast, primarily will affect the surface-water quality in Piceance Creek with only localized effects on the ground-water quality. When long- 


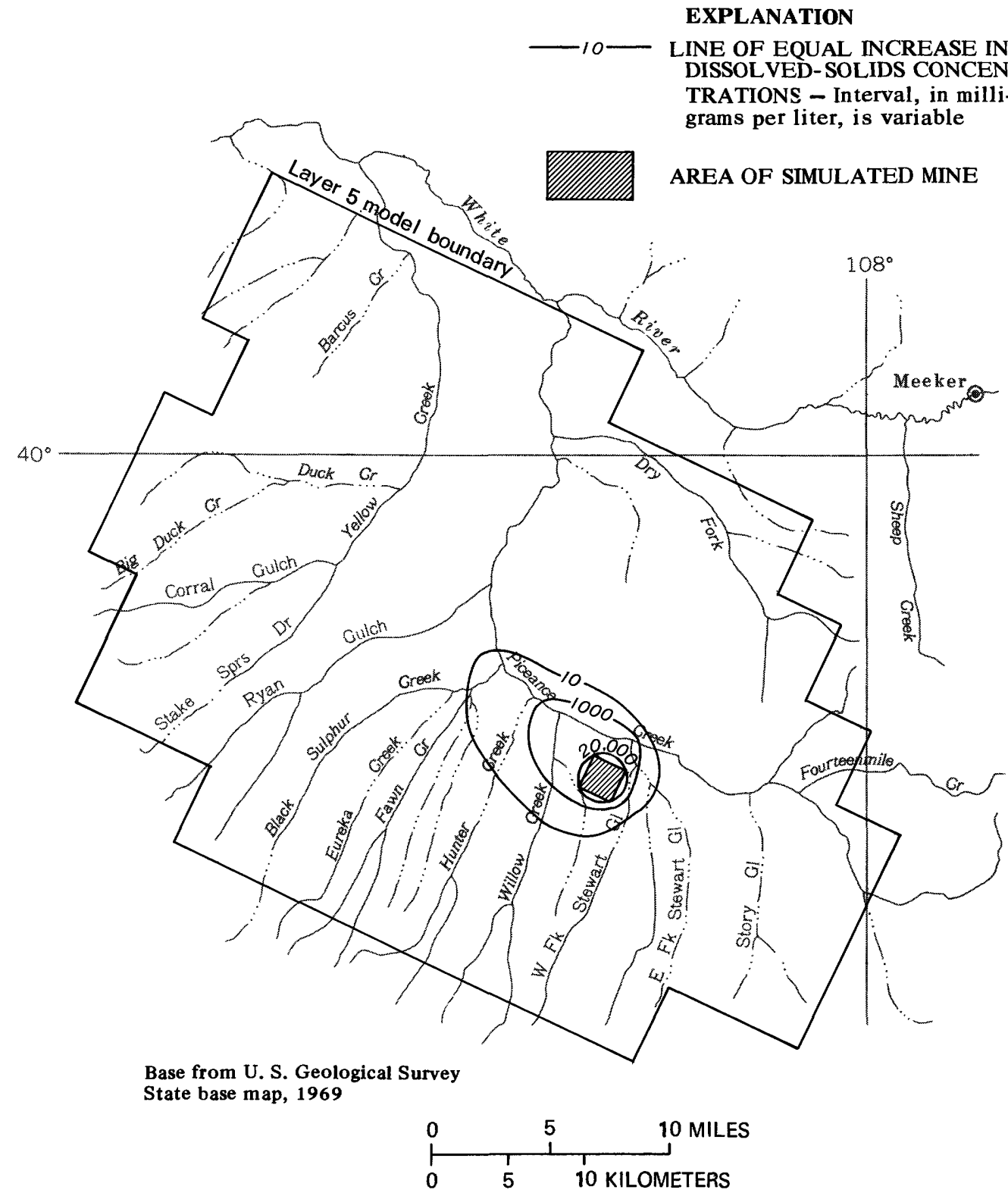

FIGURE 44.-Model-calculated increase in dissolved-solids concentrations in layer 5 after 60 years of leaching from abandoned mine at $1.3 \times 10^{5}$ pounds per day.

term conditions are considered, ground-water-quality degradation from tract $\mathrm{C}$-a will ultimately adversely affect the surface-water quality in Yellow and Piceance Creeks. This degradation will not occur soon after mine leaching begins but will begin only after large-scale and probably irreversibly ground-waterquality degradation has occurred. In tract $C-b$, the surface-water-quality degradation will occur more rapidly and may be reversible, to some extent, because large volumes of degraded ground water would not be involved.

\section{SUMMARY}

Rich oil-shale deposits occur in the Piceance basin of northwestern Colorado. The richest zones in the basin are contained in the Parachute Creek Member of the Green River Formation. Plans for mining these deposits include extensive ground-water pumping to allow underground construction of in-situ retorts for extracting the shale oil. To investigate the possible impacts of mining on the chemical quality of the water resources in the basin, a study of the 


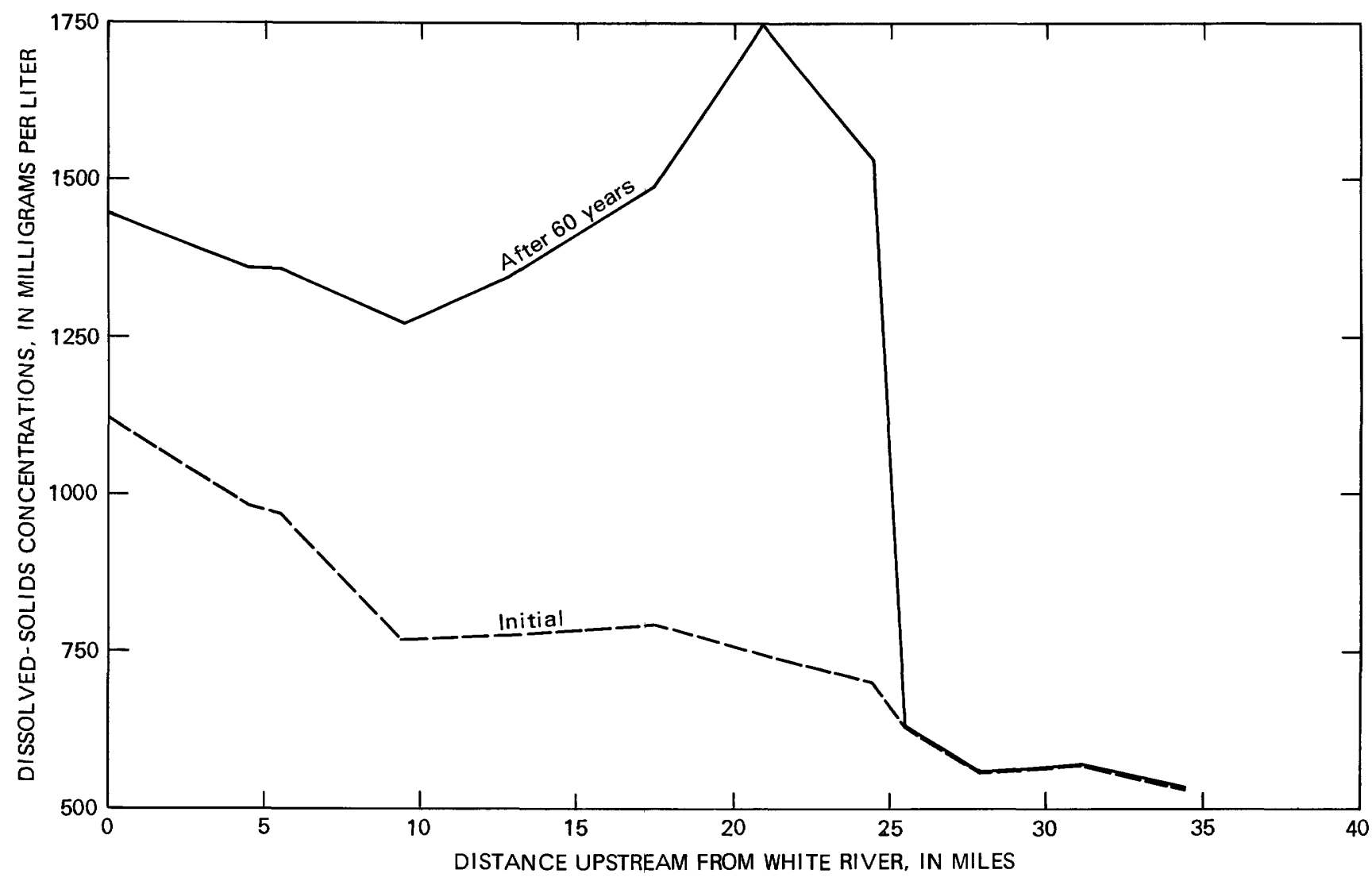

FIGURE 45.-Model-calculated dissolved-solids concentrations in ground-water discharge to Piceance Creek valley produced after 60 years of leaching from abandoned mine in tract $C-b$ at $1.3 \times 10^{5}$ pounds per day.

geochemistry of the basin was conducted in conjunction with an evaluation of the planned mining activities using a three-dimensional mathematical model that simulates solute transport in the ground-water system.

The principal aquifers in the basin occur in the Uinta Formation, composed of sandstone and siltstone, and in the underlying Parachute Creek Member of the Green River Formation, which consists of dolomitic marlstone. These units are permeable as a result of secondary porosity produced by joints, faults, collapse breccia, and solution cavities. The combined saturated thickness of these units varies from zero near the outcrops on the eastern, northern, and western margins of the basin to as much as 2,000 $\mathrm{ft}$ in the northeastern part of the basin. The hydraulic conductivity of these units varies considerably depending ondifferences in the amount of secondary porosity found in the area. Current estimates indicate a range in lateral hydraulic conductivity of 0.1 to $2.0 \mathrm{ft} / \mathrm{d}$. Vertical hydraulic conductivities range from a low of $7 \times 10^{-4} \mathrm{ft} / \mathrm{d}$ in the Mahogany zone of the
Parachute Creek Member to a maximum of $1.0 \mathrm{ft} / \mathrm{d}$ in some adjacent layers.

Infiltration of precipitation, primarily in areas with elevations greater than $7,000 \mathrm{ft}$, provides recharge to the aquifers in this closed ground-water basin. Ground water moves from the recharge areas along the eastern, southern, and western margins of the basin to the central and northern parts of the basin where it discharges by evapotranspiration and surface flow in Yellow and Piceance Creeks. Total recharge and discharge in the basin was estimated to be about $32 \mathrm{ft}^{3} / \mathrm{s}$, with the Piceance Creek drainage area receiving about 90 percent of the ground-water discharge and Yellow Creek drainage area receiving the remaining 10 percent. The flow of ground water through the basin is the result of a potentiometric gradient that is as steep as $130 \mathrm{ft} / \mathrm{mi}$ in some areas. The potentiometric head in the discharge area in the northern part of the basin is $1,600 \mathrm{ft}$ lower than the potentiometric head in the recharge area $26 \mathrm{mi}$ to the south. Potentiometric head differences as large as $240 \mathrm{ft}$ occur between different depth intervals in the 
basin-aquifer system. In recharge areas away from major stream channels, the potential exists for downward movement of ground water, while near the major stream channels, the potential commonly exists for upward movement of ground water. These vertical head differences allow water recharging the near-surface layers of the aquifer to move to depth in the aquifer system and ultimately back to the surface near the stream valleys.

Marked differences in the dissolved-solids concentration are found in the ground water. Near the recharge areas, ground water with 400 to $800 \mathrm{mg} / \mathrm{L}$ of dissolved solids is common. In areas subject to upward movement of ground water from the northern part of the Parachute Creek Member, dissolvedsolids concentrations range from about 2,000 to $45,000 \mathrm{mg} / \mathrm{L}$. The source of the dissolved constituents, the direction of ground-water movement, and differing rates of dissolution combine to produce a complex water-quality distribution in the aquifer.

The two principal stratigraphic sources of dissolved solids found in ground water in Piceance basin are the saline zone and the Uinta Formation. The saline zone is a $340-\mathrm{mi}^{2}$ area located in the lower part of the Parachute Creek Member that contains nahcolite and halite. Ground water comes in contact with these soluble saline minerals primarily by moving through faults and joints penetrating this zone or by moving laterally between bedding layers into the edges of the saline zone. Through these two mechanisms, the saline zone contributes about $1 \times 10^{5} \mathrm{lb} / \mathrm{d}$ of dissolved solids to the ground water. Infiltrating precipitation leaches salts from the unsaturated zone overlying the upper aquifer. This source of dissolution introduces about $9 \times 10^{4} \mathrm{lb} / \mathrm{d}$ of dissolved solids into the ground water of Piceance basin. The total salt load of the ground water is estimated to be $2 \times 10^{5} \mathrm{lb} / \mathrm{d}$, $1.9 \times 10^{5} \mathrm{lb} / \mathrm{d}$ of which is supplied by the above sources. The remaining dissolved solids are produced by dissolution of soluble minerals contained in the water-bearing sediments in the basin.

Chemical reactions, in addition to dissolution, that are thought to be occurring in the basin aquifers include precipitation, ion exchange, and oxidationreduction reactions. The product of the principal chemical reactions is a sodium bicarbonate water with oxidized sulfur species in the Uinta Formation and reduced sulfur species in the Parachute Creek Member. Carbonate species are produced primarily by reduction of sulfur species and dissolution of the carbonate minerals, calcite, dolomite, and nahcolite. Carbonate species are removed from the system in the northern part of the basin by calcite precipitation.
Relatively large sodium concentrations are produced by ion exchange and nahcolite and halite dissolution.

Trace constituents detected in ground water in significant concentrations include arsenic, barium, boron, fluoride, iron, lithium, and strontium. Lesser concentrations of beryllium, copper, cadmium, lead, mercury, manganese, molybdenum, selenium, and zinc were also detected. Primary evaporite minerals and primary and secondary sulfide minerals are the likely sources of the trace constituents found in the ground water.

A three-dimensional mathematical model was used to simulate the effects of mining activities on the water resources of the basin. The model simulates confined, density-dependent flow and solute transport with dispersion in nonhomogeneous, anisotropic aquifers under steady- or transient-flow conditions.

The model was calibrated by comparing the present-day potentiometric heads and dissolved-solids concentrations with model-calculated values. Model parameters, such as hydraulic conductivity, recharge rate, and dissolution rate were adjusted, within the constraints of the data, to improve the match between the measured and calculated values. An acceptable model calibration was achieved for steady-flow conditions. Calibration of transient-flow conditions was not possible due to the lack of transient conditions in the basin.

The calibrated model was used to investigate the possible effects of in-situ mining activities requiring large-scale dewatering near the two Federal prototypemine-lease tracts $\mathrm{C}-\mathrm{a}$ and $\mathrm{C}-\mathrm{b}$. This dewatering could alter the direction of ground-water flow near the mines and consequently affect the chemical quality of the ground and surface water in the area.

The simulated mine in tract $\mathrm{C}-\mathrm{a}$ was pumped at various rates and the model results indicated that: (1) Pumping the mine will decrease the dissolved-solids concentrations in ground water near the mine, and (2) increased pumping rates would further reduce the dissolved-solids concentrations in the lower aquifer. The water-quality improvement would occur because the pumping would induce downward movement of better quality ground water into deeper zones containing poorer quality water. Downgradient from the mine, the dissolved-solids concentrations would increase due to the effects of the altered direction of ground-water movement near the mine. At a longterm pumping rate of $5 \mathrm{ft}^{3} / \mathrm{s}$, the ground-water discharge to Yellow Creek valley would ultimately be reduced by about $2 \mathrm{ft}^{3} / \mathrm{s}$, and discharge to Piceance Creek valley would be reduced by $3 \mathrm{ft}^{3} / \mathrm{s}$. This reduction in flow would be accompanied by an $800-\mathrm{mg} / \mathrm{L}$ 
increase in dissolved-solids concentrations in part of Yellow Creek.

The simulated mine in tract $C-b$ was also pumped at various rates. Model results indicate that as the mine-pumping rate was increased, the dissolved-solids concentrations near the mine would remain fairly constant in all but the deepest part of the lower aquifer. A decrease in dissolved-solids concentrations of as much as $1,100 \mathrm{mg} / \mathrm{L}$ would occur in the deepest part of the aquifer if the mine were pumped at a rate of $15 \mathrm{ft}^{3} / \mathrm{s}$. Downgradient from the mine, the dissolved-solids concentrations would increase by as much as $50 \mathrm{mg} / \mathrm{L}$ in a $90-\mathrm{mi}^{2}$ area. These concentration changes also would be due to a change in the direction of ground-water movement near the mine which would allow ground water of better quality to migrate into zones containing water of a poorer quality. If the mine were pumped at a long-term rate of 15 $\mathrm{ft}^{3} / \mathrm{s}$, the rate of ground-water discharge to Piceance Creek valley would be reduced by $15 \mathrm{ft}^{3} / \mathrm{s}$. The resulting dissolved-solids concentration in the cumulative ground-water discharge would increase from 1,100 to $1,400 \mathrm{mg} / \mathrm{L}$ near the mouth of the creek.

Spent oil shale in abandoned mine retorts could contain large volumes of soluble saline minerals. From 30 to 150 million tons of saline minerals might be present in the spent shale remaining in a mine at the site proposed for tract $C-b$. Dissolution of these saline minerals through mine flooding could have a serious effection the chemical quality of the groundand surface-water resources of the Piceance basin.

Various operational procedures used in retorting the oil shale can affect the leaching rate of the minerals. The solute-transport model was used to simulate several mine-leaching rates in order to predict possible effects on the water quality in the basin. Model results for both tracts $\mathrm{C}-\mathrm{a}$ and $\mathrm{C}-\mathrm{b}$ indicate that the dissolved-solids concentrations in the aquifers increase with the rate and the duration of the leaching.

The aquifer zones with the largest hydraulic conductivity would have the largest increases in dissolved-solids concentrations, while the zones of smallest hydraulic conductivity would have the smallest increase in dissolved-solids concentrations. In tract $\mathrm{C}-\mathrm{a}$, a leaching rate of $1.3 \times 10^{5} \mathrm{lb} / \mathrm{d}$ would produce dissolved-solids concentrations near the mine in excess of $40,000 \mathrm{mg} / \mathrm{L}$ after 60 years of mine leaching. After 60 years of leaching, a $30-\mathrm{mi}^{2}$ area downgradient from the tract would have an increase in dissolved-solids concentrations in excess of 1,000 $\mathrm{mg} / \mathrm{L}$. Only minimal changes in water quality in Yellow Creek would occur after 60 years of leaching, primarily because ground water with relatively large dissolved-solids concentrations would not have reached the main areas of ground-water discharge along the creek.

Model simulations after 60 years of mine leaching in tract $\mathbf{C}-\mathbf{b}$ indicate that dissolved-solids concentrations in excess of $20,000 \mathrm{mg} / \mathrm{L}$ would occur near the mine with a leaching rate of $1.3 \times 10^{5} \mathrm{lb} / \mathrm{d}$. Under the same conditions, concentrations near tract $\mathrm{C}-\mathrm{a}$ would be in excess of $40,000 \mathrm{mg} / \mathrm{L}$. The discharge of ground water containing relatively large concentrations of dissolved solids into Piceance Creek near a leaching mine in tract $C-b$ will adversely affect the water quality in the creek. Model results indicate that in a reach of Piceance Creek near tract $\mathrm{C}-\mathrm{b}$, dissolvedsolids concentrations in cumulative ground-water discharge would increase from $750 \mathrm{mg} / \mathrm{L}$ to 1,750 $\mathrm{mg} / \mathrm{L}$ after 60 years of leaching.

The model indicates that the ground-water quality near tract $\mathrm{C}-\mathrm{a}$ will be more readily degraded by mine leachate than that near tract $C-b$. The area that would be affected by concentration increases in excess of $10 \mathrm{mg} / \mathrm{L}$ would be about $140 \mathrm{mi}^{2}$ near tract $C-a$ and about $40 \mathrm{mi}^{2}$ near tract C-b. Equal rates of leaching of abandoned mines in tracts $\mathrm{C}-\mathrm{a}$ and $\mathrm{C}-\mathrm{b}$ will likely produce much different effects on the water resources of Piceance basin. Tract C-a, located away from. perennial streams, primarily will affect the groundwater quality in a large area to the northeast of the tract. Tract $C-b$, in contrast, primarily will affect the surface-water quality in Piceance Creek, with only localized effects on the ground-water quality.

\section{REFERENCES}

Ashland Oil, Inc., Occidental Oil Shale, Inc., February 1977, Oil shale tract $\mathrm{C}-\mathrm{b}$ modifications to detailed development plan: $89 \mathrm{p}$.

Ashland Oil, Inc., and Shell Oil Co., Operator, 1976, Oil shale tract C-b, first year environmental baseline program, annual summary and trends report, November 1974 through October 1975 [submitted 'to Area Oil Shale Supervisor, Conservation Division, U.S. Geological Survey, Grand Junction, Colo.]: Denver, C-b Shale Oil Project, U.S. Department of the Interior Prototype Oil Shale Leasing Program, 546 p.

Austin, A. C., 1971, Structure contours and overburden on the top of the Maliogany zone, Green River Formation, in the northern part of the Piceance Creek basin, Rio Blanco County, Colorado: U.S. Geological Survey Miscellaneous Field Studies Map MF-309.

Bank8, C. E., and Franciscotti, B. C., 1976, 1.2 Hydrology analysis, in Adams, R.C., Banks, C. E., Bradley, W. S., Brannick, L. L., Christian, W. G., Macy, R. L., Robison, J. C. III, and Salva, M. A.,Technical and cost evaluation of candidate large scale open pit oil shale mining methods in Colorado; report prepared for U.S. Department of Interior, U.S. Bureau of Mines Contract No. SO241046: Sun Company, Suntech, Inc., Final Report, v. II, July 1976, p. 24-56, U.S. Bureau of Mines OpenFile Report 156-77. 
Campbell, D. L., 1977, Electrical soundings near Yellow Creek, Rio Blanco County, Colorado: U.S. Geological Survey Journal of Research, v. 5, no. 2, p. 193-205.

Campbell, D. L., and Olhoeft, G. R., 1977, Laboratory measurements of complex resistivity characteristics of oil shales from Suterdal no. 1 cavehole, Piceance Creek basin, Colorado: U.S. Geological Survey Open-File Report 77-410, 7 p.

Cashion, W. B., and Donnell, J. R., 1972, Chart showing correlation of selected key units in the organic-rich sequence of the Green River Formation, Piceance Creek basin, Colorado, and Uinta Basin, Utah: U.S. Geological Survey Oil and Gas Investigation Chart OC-65.

1974, Revision of nomenclatures of the upper part of the Green River Formation, Piceance Creek basin, Colorado, and eastern Uinta Basin, Utah: U.S. Geological Survey Bulletin 1394-G, 9 p.

Coffin, D. L., Welder, F. A., and Glanzman, R. K., 1971, Geohydrology of the Piceance Creek structural basin between the White and Colorado Rivers, northwestern Colorado: U.S. Geological Survey Hydrologic Investigations Atlas HA-370.

Culbertson, W. C., and Pitman, J. K., 1973, Oil shale, in Brobst, D. A., and Pratt, W. P., eds., United States mineral resources: U.S. Geological Survey Professional Paper 820, p. 497-503.

Dale, R. H., and Weeks, J. B., 1978, Hydrologic analysis of the U.S. Bureau of Mines' underground oil-shale research-facility site, Piceance Creek basin, Rio Blanco County, Colorado: U.S. Geological Survey Water-Resources Investigations 78-28, $35 \mathrm{p}$.

Desborough, G. A., and Pitman, J. K., 1974, Significance of applied mineralogy to oil shale in the upper part of the Parachute Creek Member of the Green River Formation, Piceance Creek basin, |Colorado, in Guidebook to the energy resources of the Piceance Creek basin, Colorado, Rocky Mountain Association of Geologists 25th Anniversary Field Conference: p. 81-89.

Desborough, G. A., Pitman, J. K., and Huffman, Claude, Jr., 1974, Concentration and mineralogical residence of elements in rich oil shales of the Green River Formation, Piceance Creek basin, Colorado, and the Uinta Basin, Utah-A preliminary report: U.S. Geological Survey Open-File Report 74-77, 14 p.

DeWiest, R. J. M., ed., 1969, Flow through porous media: New York, Academic Press, 530 p.

Donnell, J. R., and Blair, R. W., Jr., 1970, Resource appraisal of three rich oil-shale zones in the Green River Formation, Piceance Creek basin, Colorado: Colorado School of Mines Quarterly, v. 65, no. 4, p. 73-87.

Donnell, J. R., 1961, Tertiary geology and oil-shale resources of the Piceance Creek basin between the Colorado and White Rivers, northwestern Colorado: U.S. Geological Survey Bulletin 1082-L, p. 835-891, plates 48-59.

Duncan, D. C., 1976a, Preliminary geologic map of Rock School quadrangle, Rio Blanco County, Colorado: U.S. Geological Survey Miscellaneous Field Studies Map MF-757.

1976b, Preliminary geologic map of Square S Ranch quadrangle, Rio Blanco County, Colorado: U.S. Geological Survey Miscellaneous Field Studies Map MF-754.

1976c, Preliminary geologic map of Greasewood Gulch quadrangle, Rio Blanco County, Colorado: U.S. Geological Survey Miscellaneous Field Studies Map MF-755.

1976d, Preliminary geologic map of Wolf Ridge quadrangle, Rio Blanco County, Colorado: U.S.Geological Survey Miscellaneous Field Studies Map MF-753.

1976e, Preliminary geologic map of Jessup Gulch quadrangle, Rio Blanco County, Colorado: U.S. Geological Survey Miscellaneous Field Studies Map MF-756. 1976f, Preliminary geologic map of Yankee Gulch quadrangle, Rio Blanco County, Colorado: U.S. Geological Survey Miscellaneous Field Studies Map MF-758.

Dyni, J. R., 1974, Stratigraphy and nahcolite resources of the saline facies of the Green River Formation, Rio Blanco County, Colorado: U.S. Geological Survey Open-File Report 74-56, 27 p.

1976, Trioctahedral smectite in the Green River Formation, Duchesne County, Utah: U.S. Geological Survey Professional Paper 967, $14 \mathrm{p}$.

Ficke, J. F., Weeks, J. B., and Welder, F. A., compilers, 1974, Hydrologic data from the Piceance basin, Colorado: Colorado Water Conservation Board Water-Resources Basic-Data Release $31,246 \mathrm{p}$.

Gulf Oil Corporation-Standard Oil Company, 1977, Rio Blanco oil shale project revised detailed development plan, tract $\mathrm{C}$-a: $3 \mathrm{v}$.

Hail, W. J., Jr., 1970, Preliminary geologic map of the Barcus Creek SE quadrangle, Rio Blanco County, Colorado: U.S. Geological Survey Miscellaneous Field Studies Map MF-347. 1973, Geologic map of the Smizer Gulch quadrangle, Rio Blanco and Moffat Counties, Colorado: U.S. Geological Survey Geologic Quadrangle Map GQ-1131.

1974a, Preliminary geologic map and section of the Barcus Creek quadrangle, Rio Blanco County, Colorado: U.S. Geological Survey Miscellaneous Field Studies Map MF-619. $1974 \mathrm{~b}$, Geologic map of the Rough Gulch quadrangle, Rio Blanco and Moffat Counties, Colorado: U.S. Geological Survey Geologic Quadrangle Map GQ-1195.

1975, Preliminary geologic map of the Cutoff Gulch quadrangle, Rio Blanco and Garfield Counties, Colorado: U.S. Geological Survey Miscellaneous Field Studies Map MF-691. 1977, Preliminary geologic map of the Bull Fork quadrangle, Garfield and Rio Blanco Counties, Colorado: U.S. Geological Survey Miscellaneous Field Studies Map MF-830.

Hem, J. D., 1970, Study and interpretation of the chemical characteristics of natural water: U.S. Geological Survey Water Supply Paper 1473, 363 p.

Hite, R. J., and Dyni, J. R., 1967, Potential resources of dawsonite and nahcolite in the Piceance Creek basin, northwest Colorado, in Symposium on Oil Shale, 4th: Colorado School of Mines Quarterly, v. 62 , no. 3, p. 25-38.

Holland, H. D., 1967, Gangue minerals in hydrothermal deposits, in Barnes, H. L., ed., Geochemistry of hydrothermal ore deposits: New York, Holt, Rinehart, and Winston, p. 382-436.

INTERCOMP Resource Development and Engineering, Inc., 1976, A model for calculating effects of liquid waste disposal in deep saline aquifers, Part I-development, Part II-documentation: U.S. Geological Survey Water Resources Investigations 76-61, $253 \mathrm{p}$.

Lohman, S. W., 1972, Ground-water hydraulics: U.S. Geological Survey Professional Paper 708, 70 p.

Milton, Charles, 1971, Authigenic minerals of the Green River Formation: Wyoming University, Contributions to geology, v. 10 , no. 1 , p. $57-63$.

Mullens, M. C., 1976, Structure contours and overburden on the top of the Mahogany zone, Green River Formation, in the southern part of the Piceance Creek basin, Rio Blanco and Garfield Counties, Colorado: U.S. Geological Survey Miscellaneous Field Studies Map MF-746.

O'Sullivan, R. B., 1974, Preliminary geologic map of the Segar Mountain quadrangle, Rio Blanco County, Colorado: U.S. Geological Survey Miscellaneous Field Studies Map MF-570. 
Pipiringos, G. N., and Johnson, R. C., 1976, Preliminary geologic map and correlation diagram of the White River City quadrangle, Rio Blanco County, Colorado: U.S. Geological Survey Miscellaneous Field Studies Map MF-736.

Plummer, L. N., 1971, Barite deposition in central Kentucky: Economic Geology, v. 66, p. 252-258.

Podio, A. L., 1968, Experimental determination of the dynamic elastic properties of anisotropic rocks, ultrasonic pulse method: Austin, University of Texas, Petroleum Engineering Department, $\mathrm{Ph}$. D. dissertation, $181 \mathrm{p}$.

Robb, W. A., and Smith, J. W., 1974, Mineral profile of oil shales in Colorado Core Hole No. 1, Piceance Creek basin, Colorado, in Rocky Mountain Association of Geologists, 25th Anniversary Field Conference: p. 91-100.

Robson, S. G., 1974, Feasibility of digital water-quality modeling illustrated by application at Barstow, California: U.S. Geological Survey Water-Resources Investigations 46-73, $65 \mathrm{p}$.

Roehler, H. W., 1972, Geologic map of the Razorback Ridge quadrangle, Rio Blanco and Garfield Counties, Colorado: U.S. Geological Survey Geologic Quadrangle Map GQ-1019.

Saulnier, G. J., Jr., 1978, Genesis of the saline waters of the Green River Formation, Piceance basin, northwestern Colorado: Reno, Nevada University, unpublished Ph.D. dissertation, $120 \mathrm{p}$.

Saulnier, G.J., Jr., and Ford, T. R., 1977, Springs and fractures as indicators of potentially productive wells, Piceance basin, northwestern Colorado [abs.]:Ground Water, v. 15, no. 4, p. 326

Schmidt-Collerus, J. J., 1974, The disposal and environmental effects of carbonaceous solid wastes from commercial oil shale operations: Denver Research Institute, prepared for National Science Foundation, 240 p.

Sheppard, R. A., and Gude, A. J. III, 1973, Boron-bearing potassium feldspar of authigenic origin in closed-basin deposits: U.S. Geological Survey Journal of Research, v. 1, no. 4, p. 377-382.

Sokol, Dan, 1976, Hydrologic model, Piceance basin, Colorado, used to simulate dewatering of tract C-a: Morrison-Knudsen Co., Inc., Rio Blanco Oil Shale Project Job No. 1023-46, 36 p., 4 tables, 6 figs.

Trudell, L. G., Beard, T. N., and Smith, J. W., 1970, Green River Formation lithology and oil-shale correlations in the Piceance Creek basin, Colorado: U.S. Bureau of Mines Investigative Report 7357, 212 p.

Truesdell, A H., and Jones, B. F., 1974, WATEQ, a computer program for calculating chemical equilibria on natural water: U.S. Geological Survey Journal of Research, v. 2, p. 233-248.
U.S. Geological Survey, 1961-75, Water resources data for Colorado, Part 1. Surface water records: Denver, U.S. Geological Survey, Water Resources Division, annual State reports.

U.S. Weather Bureau, 1960, Normal October-April precipitation, 1931-1960: Denver, Colorado Water Conservation Board, map.

Ward, J. C., Margheim, G. A., and Lof, G. O., 1971, Water pollution potential of spent oil shale residue: Colorado State University for the U.S. Environmental Protection Agency, Grant No. 14030 EDB, p. 107.

Weeks, J. B., Leavesley, G. H., Welder, F. A., and Saulnier, G. J., Jr., 1974, Simulated effects of oil-shale development on the hydrology of Piceance basin, Colorado: U.S. Geological Survey Professional Paper 908, 84 p., 1 pl.

Weeks, J. B., and Welder, F. A., compilers, 1974, Hydrologic and geophysical data from the Piceance basin, Colorado: Colorado Water Conservation Board Water. Resources Basic-Data Release 35, $121 \mathrm{p}$.

Welder, F. A., 1971, Map showing joint pattern inferred from aerial photographs: Denver, Colo., Water Resources in Colorado Oil Shale Advisory Committee Study, Report on Economics of Environmental Protection for a Federal Oil Shale Leasing Program.

Welder, F. A., and Saulnier, G. J., Jr., 1978, Geohydrologic data from twenty-four test holes drilled in the Piceance basin, Rio Blanco County, Colorado 1975-76: U.S. Geological Survey Open-File Report 78-734, 132 p.

Wolff, R. G., Bredehoeft, J. D., Keys, S. W., and Shuter, Eugene, 1974, Tectonic stress determinations, northern Piceance Creek basin, Colorado, in Guidebook to the energy resources of the Piceance Creek basin, Colorado: Rocky Mountain Association of Geologists, p. 193-197.

Wright Water Engineers, Inc., 1975, Geotechnical data gathering project, hydrologic program, interpretive text, [submitted to Area Oil Shale Supervisor, U.S. Geological Survey]: Denver, Rio Blanco Oil Shale Project Progress Report 3, prepared for Gulf Oil Corp. and Standard Oil Co., sec. 1.2, 70 p.

Yen, T. F., and Chilingarian, G. V., 1976, Oil Shale, in Yen, T. F., and Chilingarian, G. V., eds., Developments in Petroleum Science: Amsterdam, Netherlands, Elesevier Scientific Publishing Company, v. 5, p. 1-12.

Ziemba, E. A., 1974, Oil shale geology, Federal tract C-a, Rio Blanco County, Colorado, in Guidebook to the energy resources of the Piceance Creek basin, Colorado: Rocky Mountain Association of Geologists, p. 123-129. 